\title{
LIETUVOS KARIUOMENÉS KARINIAI PLANAI IR IŠTEKLIAI EVENTUALAUS KARO SU LENKIJA ATVEJU 1938-1939 M.
}

\author{
Vytautas Jokubauskas \\ Klaipedos universitetas
}

XX a. ketvirtajame dešimtmetyje Lietuvos karinè vadovybė tikèjosi, kad šalis ị karą bus įtraukta prieš savo valią, jog jis vyks jos teritorijoje, bus koalicinis ir Lietuvos atžvilgiu defenzyvinis. Taigi Lietuvos kariuomenè tarpukariu aktyviai rengèsi gynybiniam karui vildamasi, jog kilus konfliktui sulauks sajungininkų paramos ir kad eventualus priešas prieš Lietuvą nukreips tik nedidelę savo pajègų dalį. 1938-1940 m. valstybè ir jos kariuomenè, plètojantis konfliktui Rytų Europoje, buvo atsidūrusi ant karo slenksčio. Tarpukariu Lietuvai grèsmę kèlè tiek SSRS, tiek Lenkija, tiek Vokietija. Lenkijos grèsmè tradiciškai, bent jau iki ketvirtojo dešimtmečio pradžios, laikyta didžiausia. Toki požiūrị i ̣ pietinị kaimyną lèmé istorinių ryšių su Lenkija patirtis ir jų padariniai Lietuvai ${ }^{1}$. Taigi realiausios 1938-1939 m. buvo galimos koalicijos su SSRS perspektyvos. Planuota, kad Vokietijos puolimo atveju ị karą bus įtraukta ir Latvija, tad abi valstybės galètų veikti bendrai sudariusios koaliciją su viena didžiujų regiono valstybių. Siekiant užsitikrinti karinị saugumą, problemiška buvo tai, kad Latvija ir Estija visą tarpukari pagrindine eventualia grèsme laikẻ SSRS, o galimais partneriais - Lenkiją ir net Vokietiją. Lietuva, atvirkščiai SSRS, su kuria iki 1939 m. rugsejo neturejo bendros sienos ir kuri buvo jos strateginé partneré, o Lenkija ir Vokietija dẻl teritorinių nesutarimų jai kèlé grèsmę. Neoficialiai Lietuvos valdančiojo elito požiūris ị Lenkiją kito bandant joje ižzvelgti galimą sajungininką karinio konflikto su Vokietija atveju. Galiausiai kylant tarptautinei ịtampai ir dẻl kolektyvinio saugumo galimybių stokos Lietuva kartu su kitomis Baltijos šalimis 1938-1939 m. pasuko neutraliteto politikos keliu ir $1939 \mathrm{~m}$. sausio $25 \mathrm{~d}$. prièmé Neutralumo istatyma ${ }^{2} .1939 \mathrm{~m}$. D. Britanija, suteikdama saugumo garantijas Lenkijai, i garantijų zoną îtrauké

\footnotetext{
1 Lopata R., Žalys V. Lietuvos geopolitinis kodas // Politologija. Vyr. red. L. Bielinis, Vilnius, 1995, Nr. 1 (6), p. 14.
}

2 Neutralumo įstatymas // Vyriausybès žinios. Kaunas, 1939 m. sausio 25 d., Nr. 632, p. 19-20. 
ir Lietuvą. Tai Lietuvos politikai žinojo ir neprotestavo. Tai buvo tarsi užuomina apie eventualų polinkị i antihitlerinę koaliciją ${ }^{3}$. Nors karo Lietuvos Respublika išvengè, tačiau nepriklausomybę prarado. Todèl natūralu, kad iki šiol ne tik istorikams, bet ir plačiajai visuomenei kyla įvairių klausimų: kodẻl Lietuvos kariuomenė nesipriešino ir ar galëjo pasipriešinti? Diskutuojama, ar Lietuvai 1938 m. vertejo priimti Lenkijos ultimatumą, o 1939 m. Vokietijai perleisti Klaipėdos kraštą. Keliamas alternatyvus klausimas: ar 1939 m. rugsèji Vokietijai siūlant nederejjo kariuomenei žygiuoti į Vilnių ir iš lenkų atsiimti sostinę?

Ypač daug kontroversiškų nuomonių kyla dèl pasipriešinimo galimybių 1940 m. birželio 15 d., kai Raudonoji armija okupavo Lietuvą. Todèl 1937 m. Lietuvos kariuomenès štabo parengtų operacijų planų Nr. 2 „V+L“ ir Nr. 3 „L“, Lietuvos ir Lenkijos pajègu ir karinio pasirengimo analizè aktuali atliekant karo istorijos tyrimus, nes Lenkijos, kaip eventualaus priešo ir galimo sąjungininko, veiksnys buvo itin svarbus Lietuvos karinio saugumo konstrukte.

Tarpukario Lietuvos karinè doktrina, manytume, buvo suformuluota apie 1926 m. kariuomenès Vyriausiojo štabo viršininku tapus gen. št. plk. ltn. Kaziui Škirpai, kai tik Lenkija buvo ịvardyta kaip grèsmę kelianti valstybė. Ketvirtojo dešimtmečio pradžioje stiprejjantis nusivylimas SSRS pozicija (ypač 1932 m. pasirašius SSRS ir Lenkijos nepuolimo sutartị) ir, pablogejjus santykiams su Vokietija, kitaip įvertintas „lenkiškasis veiksnys“ priverte lietuvius ieškoti modus vivendi su lenkais ${ }^{4}$. Maždaug 1934 m. karinės doktrinos priešų gretas papilde ir Vokietija, kuri galiausiai tapo pagrindine grèsme 5 . Atsižvelgiant ị kintančią geopolitinę padètị 1934-1935 m. Lietuvos kariuomenėje buvo atkurti 3-iasis ir 6-asis pėstininkų pulkai (toliau - PP), 1-asis artilerijos pulkas (toliau - AP) ir 3-iasis kavalerijos pulkas (toliau - KP), dauguma dislokuoti Vakarų Lietuvoje (Klaipėdoje, Plungeje, Kėdainiuose, Raseiniuose, Seredžiuje, Taurageje), ir sukurta naujų dalinių. $1935 \mathrm{~m}$. buvo įsteigta Priešlèktuvinès apsaugos rinktine, pionierių batalionas performuotas i 1-ajj inžinerijos batalioną, rugpjūčio $1 \mathrm{~d}$. įkurtas karinis laivynas, o geležinkelininkų kuopa performuota ị 2-ajji inžinerijos batalioną. $1935 \mathrm{~m}$. rugsejjo $2 \mathrm{~d}$.

3 Laurinavičius Č., Motieka E., Statkus N. Baltijos valstybiu geopolitikos bruožai XX a. Vilnius, 2005, p. 119.

4 Žalys V. Lietuvos diplomatijos istorija (1925-1940). T. 1. Vilnius, 2007, p. 27.

51933 m. Latvijos kariuomenès štabo operacijų skyriaus viršininkui plk. Hugo Rozenšteinui pasiūlius aptarti Vokietijos eventualią grèsmę, gen. ltn. Petras Kubiliūnas pasiūlymą atmetė nurodydamas, kad jis netiki, jog Vokietija keltų kokị nors pavojų. Tačiau 1934 m. Lietuvos karinè vadovybe jau svarste galimybes atitraukti kai kuriuos dalinius nuo administracinès linijos ir dislokuoti juos prie Nemuno, Vokietijos pasienyje: Žalys, V. Lietuvos diplomatinès tarnybos ir kariuomenès vadovybės sąveika ịtvirtinant Lietuvos valstybingumą 1923-1938 metais // Lietuvos nepriklausomybei - 80. Straipsnių rinkinys, Vilnius, 1999, p. 66. 
buvo reorganizuota karo aviacija, suformuotos trys - žvalgybos, naikintuvų ir bombonešiu - grupès, $1938 \mathrm{~m}$. sukurtos 2 naujos karo aviacijos eskadrilès - 7-oji ir 8-oji ${ }^{6}$. $1935 \mathrm{~m}$. birželio $7 \mathrm{~d}$. buvo suformuota 2-oji, o $1937 \mathrm{~m}$. lapkričio 1 d. - 3-ioji tankų kuopos Šarvuočių rinktinès sudètyje ${ }^{7}$.

$1935 \mathrm{~m}$. sausi Valstybès gynimo taryba kariuomenei apginkluoti ir reformuoti per 7 metus numate skirta $175 \mathrm{mln}$. $\mathrm{Lt}^{8} .1938 \mathrm{~m}$. lapkričio $1 \mathrm{~d}$. apginklavimo planas buvo papildytas ir skirta dar 59,396 mln. Lt. ${ }^{9} 1935 \mathrm{~m}$. balandžio 18 d. užsienio reikalų ministras Stasys Lozoraitis Respublikos Prezidentui Antanui Smetonai įteikè slaptą memorandumą, kuriame teigè, kad $1930 \mathrm{~m}$. Lietuvos ir Vokietijos santykiai ypač pablogèjo ir virto rimtu konfliktu, o „mūsų politikoje turi dominuoti mintis, kad iš Vokietijos mums gresia didelis pavojus. Jam atremti mes turime panaudoti visas galimas politines kombinacijas, tarp jų ir kombinaciją su Lenkija“" ${ }^{\text {" }} .1936 \mathrm{~m}$. Lietuvos kariuomenès štabo I skyriaus mokymo dalies vedejas gen. št. plk. Itn. Leonas Rupšys ir IV skyriaus viršininkas gen. št. plk. Itn. Bronius Gertus, svarstant pakrančių apsaugos klausimą, teigè, kad „dabartiniu metu aktualus priešas yra vokiečiai“"11. Tai patvirtina $1936 \mathrm{~m}$. Lietuvos užsienio reikalų ministras Stasys Lozoraitis ir krašto apsaugos ministras plk. Stasys Dirmantas, konfidencialių pokalbių su D. Britanijos karo atašè mjr. C. S. Valè (Vale) metu neslèpę, kad, nepaisant ginčo su Lenkija, potencialiausiu agresoriumi laiko Vokietiją, o konflikto su ja atveju paramos tikisi ne tik iš Talino, Rygos, Maskvos, bet ir Varšuvos ${ }^{12}$. Operacijuc plane Nr. 2 „V+L“ konstatuota: „<...> greičiausiai pirmieji puls vokiečiai, lenkai bus paskatinti išnaudoti progą - pamokyti „nesukalbamą“ kaimyną.“" ${ }^{13}$ Operacijų plane Nr. 3 „L“ rašoma, kad pagrin-

6 Vaičenonis J. Lietuvos kariuomené valstybès politinio gyvenimo verpetuose (1927-1940). Vilnius, 2004, p. 19.

7 Karo technikos daliu dvidešimtmetis 1919-1939. Kaunas, 1939, p. 199.

8 Septynerių metų ginklavimo plano lèšos buvo paskirstytos taip: 106,5 mln. Lt - ginkluotei ir amunicijai, $15 \mathrm{mln}$. Lt - karo technikai, $23 \mathrm{mln}$. Lt - karo aviacijai, $15 \mathrm{mln}$. Lt - naujų pastatų statybai, 10,7 mln. Lt - intendantūros reikmèms, $1,2 \mathrm{mln}$. Lt - karo sanitarijai ir 3,6 mln. Lt karo veterinarijai, iš jų 3,34 mln. Lt - arkliams pirkti: Krašto apsaugos ministerijos 1935-1941 metų nepaprastųjų išlaidų sąmatos paskirstymas. $L C V A$, f. 929, ap. 9, b. 163, 1. 6.

91938 m. lapkričio 1 d. Karo tarybos protokolas. $L C V A$, f. 929, ap. 9, b. 163, 1. 11-11 ap. 1.

10 Lietuvos ir Lenkijos santykiai 1917-1994. Dokumentų rinkinys. Vilnius, 1998, p. 97-100.

111936 m. gegužès 25 d. pasitarimo Kariuomenès štabe protokolas. $L C V A$, f. 929, ap. 9, b. 165, 1. 32-32 ap. 1 .

12 Žalys V. Lietuvos diplomatinès tarnybos ir kariuomenės vadovybės sąveika įtvirtinant Lietuvos valstybingumą 1923-1938 metais // Lietuvos nepriklausomybei - 80. Straipsnių rinkinys. Vilnius, 1999, p. 72.

13 Operacijų planas Nr. 2 „V+L“. 1937 m. sausio 12 d. LCVA, f. 929, ap. 3, b. 994, 1. 3-4. 
dinis galimo Lenkijos puolimo tikslas būtų pagerinti savo strateginę padètị kilus eventualiam konfliktui su SSRS arba Vokietija, o galimybės praplèsti savo valstybės teritoriją arba išsikovoti naują prieigą prie jūros laikytos mažai tikètinomis ${ }^{14}$. 1937 m. raporte krašto apsaugos ministrui plk. S. Dirmantui kariuomenès vadas gen. št. plk. Stasys Raštikis rašè: „< _..> labai sunku prileisti, kad sustiprejusi Vokietija paliktų jos niekinamai Lietuvai Klaipėdos kraštą. Vokietijos pavojui eliminuoti priemonių nẻra. Yra priemonių tik ją nutęsti ị tolimesnę ateitị, o tos priemonès yra kiek galima stiprinti savo karini pajègumą ir suartėti su valstybėmis ir jų blokais, kurie suinteresuoti Vokietijos pažabojimu. "15 Svarbiausi veiksniai, darę itaką tarpukario Lietuvos geopolitinei padéčiai, buvo SSRS, Vokietija ir Lenkija. Šios valstybès, nors ne vienu metu ir nevienodu mastu, kèlè grèsmę Lietuvos teritoriniam vientisumui ir suverenitetui ${ }^{16}$. Prasidejus Antrajam pasauliniam karui bei pasikeitus geopolitinei situacijai 1939-1940 m. jau SSRS tapo eventualia grèsme Lietuvai (nors pastarajị klausimą dar reikètų atskirai išsiaiškinti), o minètas operaciju planas Nr. 3 „L“ buvo pakoreguotas ir tapo planu „R“17.

Nuo XX a. ketvirtojo dešimtmečio vidurio Lenkijai karine prasme teko antraeilio priešininko vaidmuo, nors ideologiniu ir propagandiniu požiūriu viešajame diskurse Lenkija laikyta pagrindine grèsme. Nepaisant pakitusios doktrinos karinio planavimo srityje, aktyviai buvo dirbama, kad susiklosčius kritiškai situacijai būtų galima pasipriešinti ir Lenkijos eventualiam kariniam puolimui.

\section{LIETUVOS KARIUOMENĖS GYNYBINIŲ PLANŲ TYRIMŲ APŽVALGA}

Kiekviena kariuomenè, atsižvelgdama ị valstybès karinę doktriną, rengia karinius planus, kurie gali būti ofenzyviniai arba defenzyviniai. XX a. ketvirtajame dešimtmetyje Lietuva iš esmès ruošèsi tik gynybiniam karui, tad natūralu, kad rengè ir analogiškus - gynybinius - planus. Kai kurie iš jų istoriografijoje gana plačiai išanalizuoti, kai kurie - tik paminèti. Manytume, kad pirmasis į istoriografinę apyvartą tarpukario Lietuvos gynybinių (operacijų) planų elementą įtraukẻ Vytautas Žalys dar 1988-1990 m., aptardamas ope-

14 Operaciju planas Nr. 3 „L“. 1937 m. kovo 31 d. LCVA, f. 929, ap. 3, b. 995, 1. 3.

15 Žalys V. Lietuvos diplomatinès tarnybos ir kariuomenès vadovybės sąveika įtvirtinant Lietuvos valstybingumą 1923-1938 metais // Lietuvos nepriklausomybei - 80. Straipsnių rinkinys. Vilnius, 1999, p. 71.

16 Žalys V. Lietuvos diplomatijos istorija (1925-1940). T. 1. Vilnius, 2007, p. 28.

17 Žalys V. Dèl karinio bendradarbiavimo Baltijos antantès sistemoje (1939-1940 m.) // Lietuvos istorijos metraštis. 1988 metai. Vyr. red. V. Merkys. Vilnius, 1989, p. 67, 69. 
racijų planą Nr. 1 „V“ ir trumpai užsimindamas apie planą „R“18. Gynybos planus pristate Virginijus Liauška, tačiau kai kurie autoriaus teiginiai gana kontroversiški ${ }^{19}$. Algimantas Kasparavičius apžvelgė Lietuvos kariuomenès gynybos 1926 m. nuo Lenkijos galimybes ir planus. Analizuodamas pagrindines galimas lenkų puolimo kryptis ir pateikdamas jëgų santykio analizę, jis numate, kokių veiksmų kairioji Lietuvos vyriausybė planavo imtis valstybès kariniam saugumui stiprinti ${ }^{20}$. Operaciju planų Nr. 1 „V“ ir Nr. 3 „L“ bendruosius dèsnius, pagrindines gynybos linijas analizavo ir Jonas Vaičenonis ${ }^{21}$, pateikdamas bendrą valstybès saugumo problemų vaizdą ir kariuomenès mobilizacijos, priedangos planus ${ }^{22}$. Mokslininkas aptare ir Lietuvos Baltijos pajūrio gynybos $1934-1940 \mathrm{~m}$. problemas ${ }^{23}$. Taip pat gana išsamiai išnagrinètas $1935 \mathrm{~m}$. suformuotų pasienio apsaugos batalionų (PAB) išdèstymas ir uždaviniai ${ }^{24}$. Dainius Babilas yra išanalizavę 1926-1928 m. Kauno miesto priešlèktuvinès gynybos planus ${ }^{25}$. Juozas Algimantas Krištopaitis ir Aušra Rimaitė tyre tarpukario Lietuvos karinio saugumo problemas, strateginę padètį, trumpai pristatė operacijų planus „V“ ir „L“ bei mobilizacinius rezervus $^{26}$. Gintautas Surgailis, aptardamas tarpukario Lietuvos 1-ojo PP istoriją, pristate ir Lenku įsiveržimams stabdyti direktyvą Nr. $1 \mathrm{OP}^{27}$. Istoriogra-

18 Žalys V. Ar rengėsi kariauti su TSRS Pabaltijo valstybės // Kultūros barai, Nr. 8 (284), Vilnius, 1988, p. 57-60; Žalys V. Dèl karinio bendradarbiavimo Baltijos antantès sistemoje (1939-1940 m.) // Lietuvos istorijos metraštis. 1988 metai. Vyr. red. V. Merkys. Vilnius, 1989, p. 59-77; Žalys V. Ką byloja Lietuvos kariuomenès štabo dokumentai // Kalba Vilnius, 1989 m. birželio 23 d.

19 Liauška V. Lietuviškoji Manerheimo linija //Kalba Vilnius, 1989 m. birželio 9 d., Nr. 24, p. 12.

20 Kasparavičius A. Koalicinès liaudininkų ir socialdemokratų vyriausybės pastangos reorganizuoti kariuomenę 1926 metais // Lietuvos istorijos metraštis. 1993 metai. Vyr. red. V. Merkys. Vilnius, 1994, p. 64-66.

21 Vaičenonis J. Lietuvos kariuomenès modernizacija (1926-1939) // Darbai ir dienos. T. 21. Red. L. Gudaitis. Kaunas, 2000, p. 162.

22 Vaičenonis J. Defence problems in the Lithuanian Republic in 1934-1939 // Latvijas kara muzeja gadagrāmata. T. 7. Sas. J. Ciganovs. Rīga, 2006, 1. 153-163.

23 Vaičenonis J. Baltijos pakrantès apsaugos problemos pagal Lietuvos kariuomenès modernizavimo 1934-1940 m. planus // Kardas. Nr. 1, 2003, p. 35-37.

24 Vaičenonis J. Lietuvos šaulių sajunga valstybès gynyboje 1935-1940 m. // Lietuvos šauliu sajungos istorijos fragmentai. Red. J. Vaičenonis, S. Dovydaitis. Kaunas, 2002, p. 110-119.

25 Babilas D. Priešlèktuvinès Kauno gynybos planai 1926-1928 m. // Kauno istorijos metraštis. T. 5. Red. Z. Kiaupa. Kaunas, 2004, p. 275-291.

26 Krištopaitis J. A., Rimaitė A. Saugi valstybė: ideja ir tikrovè. Vilnius, 2004, 176 p.

27 Surgailis G. Pirmasis pèstininkų Lietuvos didžiojo kunigaikščio Gedimino pulkas 19201940 m. // Karo archyvas. Vilnius, 2009, p. 80-81. 
fijoje buvo apžvelgtas ir operacijų planas Nr. 1 „V“ (Vokietija) ${ }^{28}$.

Tarpukario Lietuvos kariuomenés planavimo ir karinio saugumo problemas paliete ir Latvijos bei Estijos istorikai. Edgaras Andersonas aptaré Lietuvos gynybinius planus „V“ ir „L“ bendrame Latvijos ir Estijos gynybos strategijos kontekste ir konstatavo, kad jie buvo visai nesuderinti, nes estai planavo gintis pasienyje (palei Narvos upę, Peipaus ir Pskovo ežerus), o latviai ir lietuviai - atsitraukę i krašto gilumą ir palikę tarp trijų kariuomenių nepridengtus tarpus ${ }^{29}$. Aivaras Petersonas, analizuodamas tarpukario Latvijos gynybinius „A“ (Austrumi - liet. „Rytai“), „D“ (Dienvidi - liet. „Pietūs“) ir „K“ (Kopējais - liet. „Bendras“) planus, trumpai pristate ir Lietuvos opera-

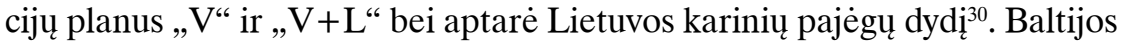
šalių, taip pat ir Lietuvos gynybinius planus bei galimas jų sąsajas (Latvijos ir Estijos) apžvelgė Estijos karo istorikas Urmas Salo ${ }^{31}$. Vytauto Didžiojo ir Klaipèdos universitetuose apginta pora magistro darbų, kuriuose nagrinejjamos 1939-1940 m. Lietuvos karinio saugumo ir gynybos problemos ${ }^{32}$.

\section{LIETUVOS KARIUOMENĖS MOBILIZACIJOS PLANAI}

Analizuojant Lietuvos kariuomenès operacijų planus būtina aptarti ir kariuomenès mobilizacijos planus, taip pat jų pokyčius 1938-1940 m. Šiuo klausimu minètą laikotarpi galima padalyti ị tris etapus: 1) iki $1939 \mathrm{~m}$. kovo 14-22 d.; 2) 1939 m. kovas-spalis; 3) 1939 m. pabaiga-1940 m. Pirmuoju laikotarpiu Lietuvos kariuomenę karo atveju po mobilizacijos turejjo sudaryti 4 pèstininkų divizijos, 2 pèstininkų brigados, 3 kavalerijos pulkai, 6 atsargos pesstininku batalionai, atsargos artilerijos pulkas, 3 atsargos kavalerijos eskadronai, karo aviacijos ir karo technikos daliniai, kariuomenès tarnybos (1 priedas). I-III péstininkų divizijos (toliau - PD) turèjo būti papildytos iki

28 Jokubauskas V. Tuščias šūvis: galimybès atremti Vokietijos karinę grèsmę 1939 metais // Istorija. T. 73. Ats. red. S. Grigaravičiūtè. Vilnius, 2009, p. 25-36.

29 Andersons E. Pabaltijo sajunga - realybė ar fantomas? Draugas: mokslas, menas, literatūra, 1974 m. liepos 13 d. Nr. 162, p. 2; Andersons E. Latvijas Bruñotie spēki un to priekšvēsture. Toronto, 1983, 1. 647-650; Andersons E. The Military situation in the Baltic States // Baltic defence rewiew. Nr. 6, 2001, Tartu, p. 113-153.

30 Pētersons A. Krustugnis. 60 gadus no tautas slēptais 1940-1945. Rīga, 2007, 1. 60-91.

31 Salo U. Estimation of Security threats and Estonian defence Planning in the 1930s. // Acta Historica Tallinnensia. Nr. 12, Tallinn, 2008, p. 35-74.

32 Babilas D. Lietuvos valstybes gynybos strategija 1939-1940 m. (karinis aspektas). Magistro baigiamasis darbas [mašinraštis VDU bibliotekoje]. Kaunas, 2003, 91 p.; Jokubauskas V. Lietuvos kariuomenés pasirengimas eventualiam karui su Vokietija 1939 m. Magistro baigiamasis darbas [mašinraštis KU BRIAI bibliotekoje]. Klaipèda, 2009, 141 p. 
karo meto dydžio, o IV PD pagrindą sudare 3-iasis PP, dislokuotas Kèdainiuose, Raseiniuose ir Seredžiuje. I pėstininkų brigada (toliau - PB) turejo mobilizuotis Klaipėdoje, Kretingoje ir Plungeje 6-ojo PP pagrindu, o II PB Kaune, jos pagrindas buvo 2-asis PP. 1939 m. kovo 14 d. Kariuomenès štabas nusprendè mobilizacijos atveju vietoj I PB formuoti V PD (17-asis PP turejjo kurtis Mažeikiuose), o Kaune planuota II PB turejjo būti suformuota kaip III PB (2 priedas). Siuos planus pakoregavo $1939 \mathrm{~m}$. kovo 22-23 d. ivvykiai, kai Vokietijai buvo perduotas Klaipeddos kraštas, dèl to teko perdislokuoti ir kariuomenès dalinius. Taigi iki 1939 m. rudens V PD pulkai turèjo būti mobilizuoti ir dislokuoti Plungèje, Telšiuose, Mažeikiuose, o tarnybos ir kai kurie padaliniai - Varniuose, Radviliškyje, Biržuose, t. y. III PD mobilizacijos teritorijoje. Esminių pokyčių I ir II PD mobilizacijos teritorijose (kur turejjo būti formuojami I, II, IV PD ir III PB) nebuvo ${ }^{33}$.

1939 m. pabaigoje-1940 m. pirmoje pusèje iki birželio mèn. Lietuvos kariuomenèje būta rimtų struktūrinių ir dislokacijos pokyčių, o tai neišvengiamai turejjo ịtakos ir mobilizacijos planams. 4-asis PP tapo būsimosios V PD pagrindu, keturi batalionai (7-asis ir 9-asis PP), skirti priedangai, mobilizacijos išvengè, nes buvo nevisiškai sukomplektuoti. Be to, buvo manoma, kad priedangos daliniai, net ir gausūs, sustabdyti priešo nepajègs ir pagrindinių gynybinių pozicijų nepasieks, todèl buvo palikti minimalios būtinos sudèties. Iš likusių 17 batalionų po mobilizacijos turejjo būti sudaryta 15 PP, vienas PP (17-asis) turejjo kurtis giliame užnugaryje (Linkuvoje, Joniškyje, Pasvalyje) neturèdamas taikos meto kadrų, tačiau jam buvo numatytas aprūpinimas ir ginkluote. 2-asis PP taip pat turejo mobilizuotis, ateityje ji buvo planuojama paversti motorizuotuoju daliniu. 1-asis PP, nors ji ir sudarė 3 batalionai, mobilizacijos atveju turèjo padidèti ir būti padalytas ị du PP. Kadangi pulkas stovejo Vilniuje, atsargos karius turejjo aprūpinti kiti pulkai, kurie savo rezervo perteklių siųsdavo ị sostinę (pagal mobilizacijos planus atsargos karių planuota pašaukti $20 \%$ daugiau nei reikejjo) ${ }^{34}$.

Mobilizacija turejjo vykti pagal iš anksto parengtus planus ir, pasak gen. št. plk. ltn. K. Škirpos, 1926 m. tam būtų prireikę apie 8-10 dienų, be to, būtų kilusi didžiausia sumaištis ${ }^{35}$. Anot E. Andersono, JAV žvalgybos

33 Mob. tv. 11 ir 12 Nr. papildomų ir kuriamų kariuomenès dalių ir įstaigų sąrašo papildymai bei pakeitimai, paskelbti nuo 1935 m. rugpjūčio 16 d. iki 1939 m. kovo 13 d. LCVA. f. 929, a. 3, b. 848, 1. 1-233.

34 Dèl keturių t. m. divizijos štabų kūrimo, 1940 m. vasario 22 d. LCVA, f. 929, ap. 3, b. 1134, 1. 13-14.

35 Vaičenonis J. Lietuvos kariuomenès modernizacija (1926-1939) // Darbai ir dienos. T. 21. Red. L. Gudaitis. Kaunas, 2000, p. 133. 
duomenimis, iki 1935 m. Lietuvos kariuomenès minètų pajėgų mobilizacija turèjo tęstis apie 12 dienų, o vẻliau decentralizuotą mobilizaciją planuota atlikti per 24-72 val. ${ }^{36}$ Tačiau $1930 \mathrm{~m}$. lapkričio $12-15 \mathrm{~d}$. bandomosios mobilizacijos Utenoje metu vieno pėstininkų bataliono mobilizacija truko 84 val. ${ }^{37}$, t. y. 12 val. trumpiau, nei buvo numatyta (4 paros) mobilizacijos tvarkaraštyje Nr. 8, taigi manyta, kad bandomoji mobilizacija visiškai pavyko ${ }^{38}$. Iki $1934 \mathrm{~m}$. valstybę parengti karui buvo skirtos 72 val. $1935 \mathrm{~m}$. buvo organizuotos 3 priedangos grupès, kurios, kartu su artilerija ir kavalerijos pulkais, gavusios įsakymą, žygiui turejjo pasirengti per 6, kiti koviniai daliniai - per 30, o tarnybos ir îstaigos - per 48 val. ${ }^{39}$ Vykstant kariuomenès reformai buvo parengti du mobilizacijos tvarkaraščiai. Pagal 11-ajj mobilizacija turejo vykti visoje valstybėje vienu metu, ir péstininkai, ir kavalerija bei artilerija žygiui turèjo pasirengti per 24, o kiti daliniai - per 30 val. Pagal 12-ajj tvarkarašti turejjo mobilizuotis papildomi daliniai, kautynių daliniai žygiui privalejo pasirengti per 30, o tarnybos ir ìstaigos - per 48 val. ${ }^{40}$ Pasienio apsaugos batalionų mobilizacijai buvo parengtas atskiras (kai kariuomenès mobilizacija dar neskelbiama, bet kyla karo pavojus) mobilizacijos tvarkaraštis Nr. 4. Numatyta, kad visais atvejais pasienio apsaugos batalionų (toliau - PAB) kūrimas turi vykti teritoriniu principu. Pirmiausia buvo rengiamasi pasitelkti pasienio policininkus ir pasienyje esančius šaulių būrius, o iš artimiausių vietų atgabenti tiek, kiek reikia, arklių, vežimų ir pakinktų ${ }^{41}$. Po kariuomenès dislokacijos ir mobilizacijos reformų $1937 \mathrm{~m}$. spalio 21-23 d. bandomoji mobilizacija buvo atlikta Kupiškyje, kur mobilizavosi vienas PP ir viena artilerijos grupe. Pèstininkai jau po 29 val., kai buvo paskelbta mobilizacija (spalio $21 \mathrm{~d}$. 15 val.), buvo pasirengę žygiui (spalio $22 \mathrm{~d}$. apie 20 val.), o artilerija - po 33 val. (spalio 22 d. apie 24 val.). Toks mobilizacijos

\footnotetext{
36 Andersons E. The Military situation in the Baltic States // Baltic defence rewiew. Nr. 6, Tartu, 2001, p. 143.

37 Aukštaičių rinktinès bandomosios mobilizacijos reliacija, 1937 m. gruodžio 23 d. LCVA, f. 1373 , ap. 1, b. 252, 1. 172-192.

38 Bandomosios mobilizacijos Utenoje reliacija, 1939 m. gruodžio 4 d. $L C V A$, f. 929, ap. 3, b. $725,1.18-18$. ap. 1.
}

39 Kasparavičius A., Mieliauskas T. Lietuvos-Lenkijos santykiai ir Lietuvos kariuomenès modernizavimas 1926-1939 metais // Karo archyvas. T. 15. Vilnius, 1998, p. 157.

40 Vaičenonis J. Lietuvos kariuomenès modernizacija (1926-1939) // Darbai ir dienos. T. 21. Red. L. Gudaitis. Kaunas, 2000, p. 161.

41 Kariuomenès štabas. III skyrius. 1936 m. sausio 14 d. Nr. 4297. LCVA, f. 929, ap. 3, b. 848, 1. 109. 
tempas Kariuomenès štabą tenkino ${ }^{42}$ ir, žinant tarpukario Lietuvos motorizacijos ir komunikacijos galimybes, atrodè didžiausias. 1939 m. rugséjo 17 d. apie 13.30 val. paskelbus dalinę kariuomenès mobilizaciją, po 20 val. visi karo meto etatai jau buvo užimti, o vėliau atsirado netgi mobilizuotuju perteklius. Po 30 val. nuo mobilizacijos pradžios (t. y. rugsėjo $18 \mathrm{~d}$. apie 20 val.) dauguma dalinių, jų vadų vertinimu, jau buvo pasirengę žygiui ${ }^{43}$.

1940 m. pradžioje buvo parengti nauji mobilizacijos tvarkaraščiai. Paskelbus tvarkaraštị Nr. 1, mobilizacija būtų vykusi visoje Lietuvoje, Nr. 2 - atskirose divizijose, Nr. 3 - taikos meto daliniai turejo būti papildyti iki karo meto sudèties. Tvarkaraščio Nr. 3 buvo du variantai: „A“ - skirtas Vakarų Lietuvai (II, III ir IV PD), „B“ - Rytų Lietuvai (I ir V PD). Tvarkaraštis Nr. 4 buvo parengtas PAB mobilizacijai organizuoti „senojoje“ Lietuvos teritorijoje (pasienyje su Vokietija ir Suvalkų kraštu - I-VII PAB), Nr. 5 buvo skelbiama oro sekejų, o Nr. 6 - Intendantūros ir sanitarijos dalinių mobilizacija ${ }^{44}$.

Kariuomenès mobilizacija, siekiant dalinius apsaugoti nuo priešo aviacijos antpuolių, XX a. ketvirtojo dešimtmečio antroje pusėje, remiantis Suomijos ir Estijos pavyzdžiu, buvo decentralizuota. Paskelbus mobilizaciją kariuomene turejjo rinktis daugiau nei trisdešimtyje mobilizacijos centrų, kuriuos sudarė nuo keliasdešimties tūkstančių (Kaune apie 31 000, Panevėžyje ir Šiauliuose po 11000$)$ iki keliasdešimties karių. Be to, kai kuriose Lietuvos vietovėse buvo numatyta kurti Intendantūros sandėlius, kurie turejo rūpintis provizijos iš gyventojų rinkimu. Mobilizacijos centrai buvo ikkurti toliau nuo Lenkijos ir Vokietijos sienų, dauguma atsargos karių turèjo rinktis vietovèse tarp Dubysos ir Šventosios upių ${ }^{45}$.

Latvijoje mobilizacija turejo vykti labiau centralizuotai ir lečiau, remiantis ne teritoriniu, o ,politiniu“ principu - planuota mobilizuoti tik patikimus atsargos karius ${ }^{46}$. Daliniai turejo kurtis stambiuose mobilizacijos centruose,

\footnotetext{
42 Aukštaičiu rinktinès bandomosios mobilizacijos reliacija. 1937 m. gruodžio 23 d. LCVA, f. 1373 , ap. 1 , b. $252,1.172-192$.

431939 m. rugsëjo mènesio mobilizacijos reliacija. 1940 m. gegužès 4 d. LCVA, f. 929, ap. 5, b. $547,1.4$, ap.1. 17.

44 Kariuomenès mobilizacijos reikalu. 1940 m. LCVA, f. 929, ap. 5, b. 591, 1. 29-31.

45 Jokubauskas V. Tuščias šūvis: galimybès atremti Vokietijos karinę grèsmę 1939 metais // Istorija. T. 73. Ats. red. S. Grigaravičiūtè. Vilnius, 2009, p. 27-28.

46 Atsargos divizija, skirta papildyti kariais likusias septynias PD, atsargos karius i pulkus Rygoje, Ventspilyje ir Liepojoje turejo siųsti tik iš politiškai patikimų regionų (Kuršo, Žiemgalos ir Rygos miesto): Kuzmins, V. Latvijas brunoto spēku aizsardzības pläni. 1939. g. rudens . 1940. g. vasara. Magistro baigiamasis darbas [mašinraštis Latvijos universiteto bibliotekoje]. Ryga, 2002, 1. 48-50.
} 
Rygoje planuota mobilizuoti trečdali visų PP ( 8 iš 24$)^{47}$. Lietuvoje tik Kaune numatyta mobilizuoti $3 \mathrm{PP}$ (iš planuotu $17 \mathrm{PP}$, t. y. 17,6 \%), visi kiti $14 \mathrm{PP}$ turèjo mobilizuotis kituose miestuose. Mobilizacija Latvijoje turejo trukti ilgiau: apie $50 \%$ dalinių privalëjo pasirengti per 48 val., o likusieji - per 4-5 dienas ${ }^{48}$.

Dèl geopolitinès padèties Lietuvoje saugaus užnugario nebuvo. Visa šalis laikyta „operaciniu ruožu“, o pramonei ir atsargoms telkti labiausiai tiko Joniškis, Šiauliai, Radviliškis, Panevėžys ir Rokiškis. Konstatuota, kad karo meto gamybos išsivystymo lygis Lietuvos sąlygomis „nèra esminis reikalas“, jog karo atveju organizuoti jos nebus įmanoma, todèl reikès verstis naudojant tik turimas atsargas ${ }^{49}$. Steigti karo pramonès centrus Lietuvoje dèl nedidelés teritorijos ${ }^{50}$ buvo neperspektyvu, nes galimybès kilus karui jais naudotis būtų buvusios ribotos ${ }^{51}$. Pagrindinès Lietuvos pajègos pagal „L“ ir „V“ planus turejjo telktis už pagrindinių gynybos linijų tarp Dubysos-Ventos ir Nevéžio-Mūšos upių, kur buvo įrengta daugiausiai slaptų aerodromų

47 I PD štabas, 1-asis ir 2-asis PP, 1-asis AP - Liepoja; II PD štabas, 4-asis ir 5-asis PP, 2-asis AP - Ryga, 16-asis PP - Krustpilis; III PD štabas, 13-asis PP - Gulbenè, 7-asis PP - Aluksnè, 9-asis PP - Rezeknė, 3-iasis AP - Krustpilis; IV PD - Daugpilis; V PD štabas, 8-asis PP, 5-asis AP - Cèsis; VI PD - Ryga, VII PD štabas, 19-asis PP ir 7-asis AP - Jelgava, 20-asis PP - Ryga, 21-asis PP - Tukumas; tankų pulkas - Ryga, KP ir Raitosios artilerijos baterija - Daugpilis, Atskirasis kavalerijos divizionas - Jelgava, 5 šarvuoti traukiniai - Daugpilis, I dviratininku batalionas - Cèsis, II - Ryga, III - Ventspilis. Be to, pakrančių apsaugos (krašto) AP, Daugavgrīva, zenitinès AP, inžinierių pulkas, karo aviacijos pulkas, karo laivynas: Salo U. Eesti kaitseväe valmisolek sõjaks ja vastupanuvõimalused 1939. aastal. Magistro baigiamasis darbas [PDF]. Tartu, 2005 [žiūrèta 201008 20]; <http://www.hot.ee/laanemk6/EESTI_KV_Valmisoleks_ sojaks39_aastal.pdf>.p. 309-311.

48 Pasienyje su SSRS buvę 7-asis, 9-asis, 10-asis ir 11-asis PP žygiui turèjo pasirengti per 3-5 val., likusieji III ir IV PD daliniai - per 20-40 val., I PD - per 16-36 val., II PD - per 20-36 val., V PD - per 48 val., VI PD - per 60-100 val., VII PD - per 36-72 val. Tokie mobilizacijos tempai buvo per lèti ketvirtojo dešimtmečio sąlygomis, tačiau karo su Vokietija atveju, pastarajai pirmai užpuolus Lietuvą, tikètasi, kad Lietuvos pajègos pajėgs sulaikyti vermachtą keletą dienų ir Latvijos kariuomenè spès mobilizuotis ir susitelkti reikiamomis kryptimis. SSRS puolimo atveju planuota, kad dèl prastos pasienio infrastruktūros Latgaloje Raudonoji armija galès pulti tik siaurais barais palei kelius ir latviu priedangos pajejgos jas trumpam sulaikys ir laimès laiko pagrindinių pajègų mobilizacijai atlikti: Kuzmins V. Latvijas bruṇoto spēku mobilizācijas un aizsardzības plāni 1939. gada beigās-1940. gada sākumā // Militārais apskaits. Red. K. Krēsliṇš. 2009, Nr. 3/4, 1. 49-56.

49 Kariuomenès štabo III 1937 m. gegužès 24 d. kariuomenès tiekimo viršininkui. LCVA, f. 1, ap. 1, b. 385, 1. 49-49 ap. 1.

50 Iš Lydos karo lèktuvai Kauną galëjo pasiekti per 27 min., o Šiaulius - per 51 min.: Tarvydas S. Geopolitika // Lietuvos geopolitika. Sud. S. Vaitiekūnas. Vilnius, 1991, p. 273.

51 Šimkus A. Valstybė ir ekonominiai klausimai taikos ir karo metu // Mūsų žinynas. 1936, Nr. 140, p. 412. 
(aikštelių), pastatytos Linkaičių ginklų dirbtuvès, taip pat buvo svarbūs geležinkelio mazgai - Šiauliai ir Radviliškis.

Mobilizacijos planai kito atsižvelgiant ị kintančią geopolitinę ir vidaus padètí. Jie nuolatos buvo tobulinami, tačiau teritorinis mobilizacijos principas, kurio laikytis pradèta XX a. ketvirtojo dešimtmečio viduryje, išliko, nes tai leido kiek įmanoma greičiau mobilizuoti ir apsaugoti nuo gausių priešo aviacijos antskrydžių ir sunaikinimo pajègas.

\section{LIETUVOS KARIUOMENĖS MOBILIZACINIS KARIŲ REZERVAS}

1939 m. vienas pirmụjų Lietuvos geopolitikų Stanislovas Tarvydas rašè: „Valstybės ginkluotųjų jėgų dydis turi atitikti tuos interesus, kuriuos ji rengiasi kare ginti. Didžiosios valstybès turi didelius interesus. Jos turi turèti dideles kariuomenes. Mažosios valstybès gina kuklesnius interesus, jų ir kariuomenès gali būti mažesnès. Tikras valstybès saugumas nepriklauso nuo to, ar ji yra didelè, ar maža, bet tik nuo to, ar jos ginkluotosios pajègos suderintos su jos interesų dydžiu, ar ji yra gerai kariškai organizuota, ar jos kovotojai yra narsūs ir didžios moralès. " ${ }^{2}$ Aptariant mobilizuotos Lietuvos kariuomenès, arba ginkluotųjų pajėgų, dydi (karo atveju turëjo būti pasitelkti ir šauliai bei VRM pavaldūs pasienio policininkai), verta pažymèti, kad skirtingi autoriai nurodo nevienodą karių skaičių - nuo $125433^{53}$ iki $150000^{54}$. Tačiau dèl lèšų stygiaus Lietuva negalèjo ị reguliariają kariuomenę mobilizuoti visų karo tarnybai tinkamų 250 000-300 000 vyrų, o tik apie 130 000, kuriuos būtų ịstengusi apginkluoti ${ }^{55}$. Latvijos istorikas Edgaras Andersonas nurode, jog teoriškai Lietuva galèjo mobilizuoti 250000 vyrų, bet dèl ginkluotès stokos buvo pašaukta $120000-135000^{56}$, o karo meto kariuomenę turejjo sudaryti penkios péstininkų divizijos ir dvi kavalerijos brigados $^{57}$. Henris L. Gaidis taip pat teigia, kad mobilizuotoje kariuomenejje turèjo būti apie 120000 vyrų, nors autorius kiek kontroversiškai nu-

52 Tarvydas S. Geopolitika // Lietuvos geopolitika. Sud. S. Vaitiekūnas. Vilnius, 1991, p. 313.

53 Vaičenonis J. Lietuvos kariuomenè valstybès politinio gyvenimo verpetuose (1927-1940). Vilnius, 2004, p. 32.

54 Surgailis G. Lietuvos kariuomene 1918-1998. Vilnius, 1998, p. 28.

55 Vaičenonis J. Defence problems in the Lithuanian Republic in 1934-1939 // Latvijas kara muzeja gadagrāmata. T. 7. Sas. J. Ciganovs. Rīga, 2006, 1. 161.

56 Andersons E. Latvijas Bruñotie spēki un to priekšvēsture. Toronto, 1983, 1. 647.

57 Andersons E. Pabaltijo sajunga - realybė ar fantomas? // Draugas: mokslas, menas, literatūra. 1974 m. liepos 13 d., Nr. 162, p. 2. 
rodo pèstininkų ir artilerijos pulkų skaičių ${ }^{58}$. Minètas skaičius sutampa su brg. gen. Stasio Raštikio atsiminimuose nurodytu, todèl greičiausiai iš ten ir yra paimtas ${ }^{59}$. Kritiškai tenka vertinti Lietuvių enciklopedijoje nurodytą 200000 karių skaičių, kuris po 1990 m. pateko ị istoriografinę apyvartą. Tokio dydžio kariuomenei Lietuva neturejo ne tik sunkiosios ginkluotès, bet ir šautuvų, be to, sunku įsivaizduoti, kokio dydžio turejjo būti nurodytos 4 PD ir 2 PB $^{60}$. Tenka pažymèti, kad analogiškas 200000 karių skaičius (pajègų dydis), remiantis užsienio kariniais leidiniais, nurodomas ir tarpukario Lietuvos periodikoje ${ }^{61}$. Remiantis $1939 \mathrm{~m}$. liepos 7 d. Kariuomenès intendantūros duomenimis apie mobilizuotos kariuomenès aprūpinimą duona igulose, galima teigti, kad pagal tvarkarašti Nr. 12 visuotinès mobilizacijos atveju kariuomenè igulose turejjo padidèti iki maždaug 122400 karių. Planuota, kad iš $20 \%$ papildomai, nei numatyta karo meto etatų sąrašuose, pašauktų atsargos karių atvyks apie pusè, t. y. $10 \%^{62}$. Pastaroji prielaida buvo tiksli, nes 1939 m. rugsèjo 17 d. Lietuvoje paskelbus dalinę mobilizaciją, i karinius dalinius neatvyko tik apie 10,17 \% planuoto atsargos karių skaičiaus ${ }^{63}$. Tačiau dalis Lietuvos kariuomenès buvo mobilizuota pagal tvar-

58 Nurodoma, kad kariuomeneje turèjo būti 19 PP, 12 PAB, 4 AP ir 3 KP: Gaidis L. H. A History of The Lithuanian Military Forces in World War II 1939-1945. Chicago, 1998, p. 18.

59 Anot brg. gen. S. Raštikio, Lietuva galejo mobilizuoti iki 250000 vyrų, tačiau karo atveju i kariuomenę buvo planuojama pašaukti tik 120 000-135 000: Raštikis S. Ivykiai ir žmonès. T. 3. Kaunas, 1996, p. 301.

60 Minètus 200000 padalijus iš 16 PP (tai - 4 PD ir 2 PB ekvivalentas) gaunama 12500 karių, kurie beveik galètų sudaryti diviziją, o ne pulką: Lietuvių enciklopedija. T. 15. Vilnius, 1991, p. 110.

61 Remiantis Deutsche Wehr 1934 m. informacija, kuri buvo perspausdinta Karde, Lietuvos kariuomenę taikos metu sudarè 18000 karių, o karo metu - 200 000: Mūsų ir kaimynų kariuomenès 1934 m. sausio mèn. Kardas, 1934, Nr. 4, p. 79; 1936 m. Karde, remiantis Kreuz Zeitung, rašoma, kad Lietuvos taikos meto kariuomenę sudare 22 000, o karo meto - 200000 karių: Kas pradejjo ginklavimosi lenktynes? // Kardas, 1936, Nr. 6, p. 171.

62 I PD teritorijoje turëjo mobilizuotis apie 37 700, II PD - 43 300, III PD - 41400 karių. 46 igulose apie 28900 karių turèjo būti taikos metu, o apie 93500 planuota pašaukti. Apie 89000 karių buvo numatyta skirti ị kautynių dalinius: Mobilizuojamos kariuomenès aprūpinimo duona lentelè (pagal mob. tvarkarašti Nr. 12), 1939 m. liepos 7 d. LCVA, f. 506, ap. 1, b. 209, 1. 54-58; 1938 m. kovo mèn. duomenimis, panašus skaičius karių - 122600 - turèjo būti mobilizuotas 33 igulose, apie 8400 iš jų buvo numatyta pašaukti kaip $10 \%$ planuotų „viršlimitinių“: Mobilizuojamos kariuomenès aprūpinimo duona lentelè (pagal mob. tvarkaraštị Nr. 12), 1938 m. kovas. LCVA, f. 506, ap. 1, b. 209, 1. 15-17.

63 Buvo planuota pašaukti 1871 karininką ir 72867 karius, šaukimo lapeliai buvo įteikti 1798 karininkams ir 63582 kariams, dèl gyvenamosios vietos pakeitimo, ligos, mirties, įkalinimo ar nežinomų priežasčių šaukimo lapelių nepavyko ịteikti 73 karininkams ir 9285 kariams, tačiau ị paskyrimo vietas atvyko daugiau nei buvo įteikta šaukimų - 2,68\%, 1852 karininkai ir 65282 kariai (atvykusiuju skaičius apytikslis, nes Vilkaviškio apskrities, iš kurios buvo planuota pašaukti 68 karininkus ir 4191 karị, komendantas nepateike duomenų, tik konstatavo, kad atvyko dauguma): Apskričių mobilizacijos vykdymo žinios, 1939 m. LCVA, f. 929, ap. 5, b. 560, 1. 3-177. 
karašti Nr. 4, t. y. pasienio apsaugos batalionai ir juos papildyti numatyti kariai ị minètą Intendantūros planą neįtraukti. $1939 \mathrm{~m}$. vieną PAB turèjo sudaryti 25 karininkai, 898 kariai ir 132 arkliai $^{64}$, taigi visuose 12 PAB turejo būti 11076 vyrai (300 karininkų ir 10776 kariai). Sudejję mobilizuojamų ir pagal abu tvarkaraščius (Nr. 4 ir Nr. 12) numatytų karių skaičių, gauname maždaug 133500 vyrų kariuomenę.

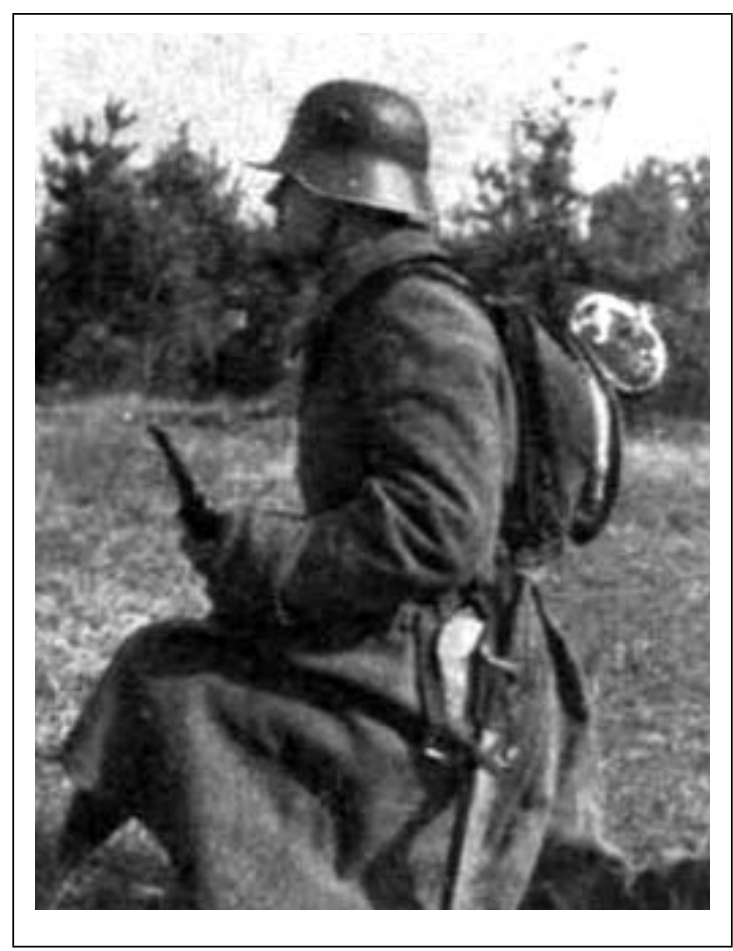

Lietuvos kariuomenès pėstininkas. Kardas, 1936 m.

Gen. št. plk. Kazio Škirpos pateiktais duomenimis, $1932 \mathrm{~m}$. Lietuvoje buvo $386 \quad 505 \quad 20-45 \quad \mathrm{~m}$. vyrai. Taip pat teigiama, kad „atmetus“ apie $20 \%$ tarnybai netinkamų asmenų, kurie būtų nuo jos atleisti arba jos vengtu, lieka 309200 vyrų $^{65}$. Kai kurių karininku žiniomis, $1935 \mathrm{~m}$. Lietuvoje buvo apie 300000 mobilizuotinų vyrų $(12,2 \%$ visų gyventojų $)^{66}$, o 1937 m. - 382822 $(15,145 \%$ gyventoju $)$ karo tarnybai tinkami vyrai ${ }^{67}$. Remiantis Italijos kariuomenès pavyzdžiu teigta, kad 1937 m. Lietuvoje

64 Kariuomenès intendantūra, 1939 m. rugsèjo 14 d. LCVA, f. 929, ap. 5, b. 449, 1. 116.

65 Vaičenonis J. Lietuvos kariuomenès Vyriausiojo štabo viršininko plk. K. Škirpos Lietuvos kariuomenès vystymo planas // Karo archyvas. T. 21. Vilnius, 2006, p. 345-346.

66 Baltrušis J. Maisto produktų ištekliai Lietuvoje karo perspektyvoje. Mūsų žinynas. 1935, t. 28, Nr. 122, p. 461.

6783695 naujokų rezervas (jaunuoliai nuo 18 iki 21 m.), 117651 I rūšies ir 53457 II rūšies atsargos kariai, apsaugoje 44019 vyrų: Gen. št. plk. ltn. Šova, Kaip tobulintina mūsų kariuomenès organizacija, 1937 m. LCVA, f. 929, ap. 2, b. 1047, 1. 9, 13. 
tuo metu gyveno 2526535 gyventojai, teoriškai buvo galima ị kariuomenę mobilizuoti apie $20 \%$ populiacijos, t. y. 505000 vyrų. Tačiau dėl prastesnès gyventojų sveikatos būklès, didesnio mirtingumo ir antropologinio tipo ypatumų (ūgio, svorio) bei trumpesnio šaukiamojo amžiaus tokio skaičiaus vadovybe negalejjo mobilizuoti. Lietuvoje karo prievolę taikos metu turejjo atlikti 21-45 m. (šauk. amžiaus diapazonas - $24 \mathrm{~m}$.), karo metu - 18-45 m. (šauk. amžius - 27 m.), o Italijoje - 18-55 m. (šauk. amžius - 37 m.) vyrai ${ }^{68}$. Estijoje kariuomenès atsargoje ir apsaugoje vyrai buvo iki 55 m., o inteligentai - iki $60 \mathrm{~m} .{ }^{69}$, Suomijoje - iki $60 \mathrm{~m} .{ }^{70}$, Latvijoje - iki $50 \mathrm{~m}$., o karo valdininkai - iki $55 \mathrm{~m} .^{71}$ Vokietijoje karių rezervą sudarè vyrai iki $45 \mathrm{~m}$. , o Rytu Prūsijoje - iki $55 \mathrm{~m}^{72}$ Prancūzijoje ị armiją pirmą kartą taip pat buvo šaukiami $21 \mathrm{~m}$. jaunuoliai, karo prievolininkai jie būdavo 28 metus, t. y. iki $49 \mathrm{~m}$. imtinai ${ }^{73}$. Lenkijoje karo prievolę vyrai nuo 21 iki $50 \mathrm{~m}$. turejjo atlikti per 29 metus $^{74}$. Taigi Lietuvoje atsargoje vyrai būdavo trumpiausiai, o tai savaime mažino ir atsargos karių skaičių, tačiau šalis dèl ribotų materialiniu išteklių poreikio didinti jų skaičiaus neturèjo, nes karo atveju paprasčiausiai nebūtų įstengusi visų apginkluoti.

1923 m. surašymo duomenimis, Lietuvoje 18-44 m. amžiaus vyrai sudarè apie $38 \%$ visos vyrų populiacijos. $1937 \mathrm{~m}$. gruodžio $31 \mathrm{~d}$. Lietuvoje gyveno 2549668 gyventojai, iš jų - 1228579 vyrai, 18-44 m. amžiaus - apie $467000^{75}$. Kiti autoriai nurodo, kad Lietuvoje tuo metu gyveno 500000

68 Gen. št. plk. A. Šova. Kariuomenès organizacija, 1939 m. LCVA, f. 506, ap. 1, b. 243, 1. 4.

69 Atsargos kariai buvo skirstomi ị 3 grupes: I grupei priklausė vyrai iki 45 m., jau atlikę privalomąą karo tarnybą, II grupei - 30-45 m. vyrai, netarnavę kariuomeneje, III - 17-30 m. vyrai, tarnybai tinkami, bet dar netarnavę: Estijos kariuomené, 1938 m. liepos 1 d. LCVA, f. 929, ap. 2, b, 1062, 1. 20-21.

70 Suomijoje karo tarnybai tinkamais buvo laikomi 17-60 m. vyrai, i tikrają karo tarnybą suomiai buvo šaukiami $21 \mathrm{~m}$., po 350 dienų tarnybos iki $40 \mathrm{~m}$. likdavo I rūšies atsargoje, II rūšies atsargoje : 1) kariuomenèje tarnavę 41-60 m. vyrai, 2) nuo karo tarnybos atleisti, bet jai tinkami, 3) 17-21 m. vyrai ir tie, kurių tarnybos laikas buvo atidetas: Suomijos kariuomenè, $1939 \mathrm{~m}$. rugpjūčio 28 d. $L C V A$, f. 929 , ap. 2, b. $101.9-10$.

71 Latvijoje karo prievolę turëjo atlikti $17-50 \mathrm{~m}$. vyrai, iki $55 \mathrm{~m}$. karo valdininkai, atsargoje buvo vyrai iki 40 m., apsaugoje - iki 50 m.: Latvijos kariuomenè, 1938 m. LCVA, f. 929, ap. 2, b. $1065,1.12$.

72 Vokietijos karinè veikla 1939 m., 1940 m. gegužès 1 d. LCVA, ap. 2, b. 1084, ap. 1. 18.

$733 \mathrm{~m}$. prancūzai buvo nuolatinès parengties atsargoje, $16 \mathrm{~m}$. - I rūšies, $8 \mathrm{~m}$. - II rūšies atsargoје: История западноевропейских армий. Ред. В. А. Золотарев. Москва, 2003, с. 173-174.

74 Jurga T. Oborona Polski 1939. Warszawa, 1990, s. 43.

75 18-19 m. - apie 4,82 \%, 20-44 m. - 33,25 \% visos vyru populiacijos (bendrai - 38,07 \%): Lietuvos statistikos metraštis. 1937. Kaunas, 1938, p. 13-16. 
karo tarnybai tinkamų vyrų ${ }^{76}$.

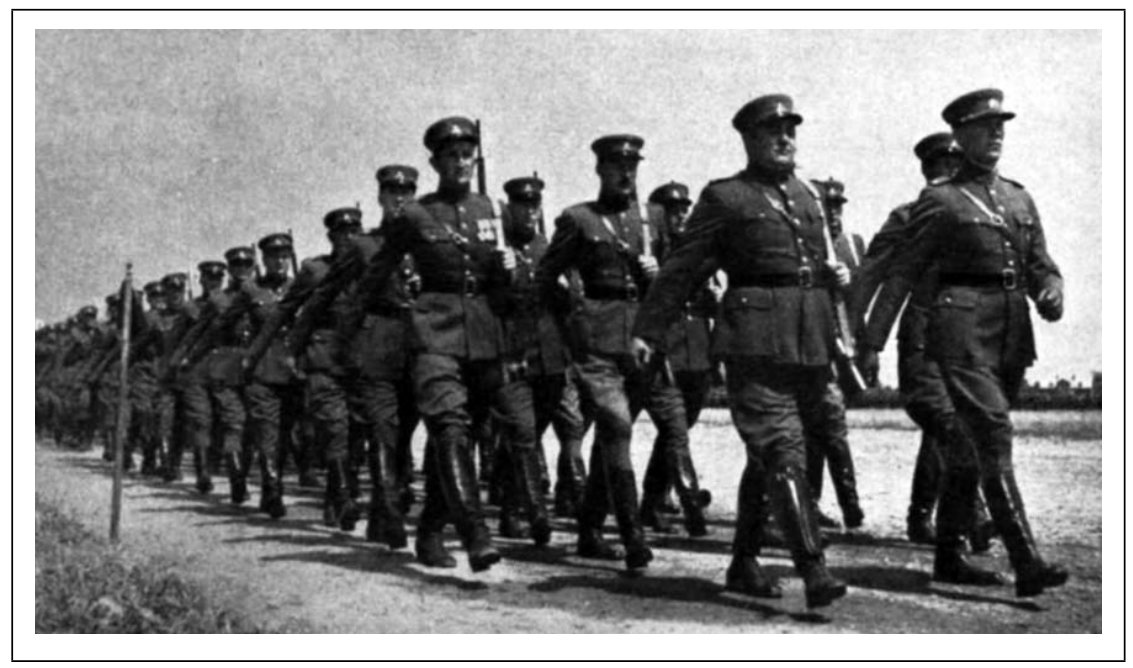

Lietuvos šaulių sajungos nariai parado metu. Kardas, 1939 m. (V. Augustino nuotrauka)

Vertinant visas 1938-1940 m. Lietuvos ginkluotąsias pajègas būtina atkreipti dėmesị ir ị šaulius, pasienio ir viešosios tvarkos policininkus, kurie turejjo, jei ne fronte ar priešo užnugaryje, tai bent savame užnugaryje, vykdyti svarbias apsaugos ir tvarkos palaikymo funkcijas. Aptariamuoju laikotarpiu Lietuvoje buvo apie 3500 pasienio policininkų ${ }^{77} .1939 \mathrm{~m}$. spali viešojoje, geležinkelių ir rezervo policijoje tarnavo 2903 pareigūnai $^{78} .1935 \mathrm{~m}$. Lietuvos šaulių sajungoje (LŠS) buvo 33276 nariai, iš jų 24976 - rikiuo-

76 A. Kasparavičius ir T. Mieliauskas teigia, kad 1939 m. „karinei prievolei priklausè ir jai buvo tinkamų 500 000, t. y. 20 \% visų Lietuvos gyventojų“.: Kasparavičius A., Mieliauskas T. Lietuvos-Lenkijos santykiai ir Lietuvos kariuomenès modernizavimas 1926-1939 metais // Karo archyvas. T. 15. Vilnius, 1998, p. 157; Analogišką skaičių nurodo ir H. L. Gaidis: Gaidis L. H. A History of The Lithuanian Military Forces in World War II 1939-1945. Chicago, 1998, p. 18; J. A. Krištopaitis ir A. Rimaite rašo, kad Lietuvoje paskelbus visuotinę mobilizaciją kariuomenę planuota padidinti iki 150000 karių, tinkamų karo tarnybai vyrų Lietuvoje buvo 500 000, o mobilizacinį rezervą sudarè apie 120000 karių: Krištopaitis J. A., Rimaitė A. Saugi valstybé: idëja ir tikrove. Vilnius, 2004, p. 96.

77 Raštikis S. Itvykiai ir žmoness. T. 3. Kaunas, 1996, p. 299.

78 Mančinskas Č. Policija Lietuvoje 1918-1940 metais. Vilnius, 1998, p. 24-25. 
tès kariai, organizacija turejjo 7371 šautuvą ir 32 kulkosvaidžius ${ }^{79}$. Buvęs kariuomenès vadas brg. gen. S. Raštikis atsiminimuose mini, kad 1939 m. Lietuvoje buvo 55000 rikiuotès šaulių ${ }^{80}$. Kaip teigia Arvydas Pociūnas, tuo metu LŠS priklause 13731 šautuvas, 89 kulkosvaidžiai ir 316 pistoletų $^{81}$. 1939 m. balandžio mėn. duomenimis, organizacija turejjo 14587 šautuvus ir karabinus, 255 lengvuosius ir 1 sunkųji kulkosvaidžius, 316 pistoletǔ, 3056 granatas, 464 kardus $^{82}$. Vytenis Statkus nurodo, kad 1940 m. LŠS buvo 42000 rikiuotès šaulių, apie 15000 moterų šaulių ir apie 5000 šaulių rèmejjų ${ }^{83} .1940$ m. pradžioje LŠS tarnavo 48107 rikiuotès šauliai, sajunga turejjo 27478 šautuvus, 378 lengvuosius kulkosvaidžius, 3160 pistoletų, 3504 granatas, 3241468 šovinius $^{84}$. Tam tikras skaičius šaulių mobilizacijos metu galejjo būti pašaukti ị reguliariosios kariuomenès dalinius, šauliai sudarè ir dalị PAB. Pavyzdžiui, 1938 m. II PD teritorijoje tarnavo 13098 rikiuotès šauliai, iš jų 6510 po mobilizacijos turejo likti rinktinèse: 1861 šaulys saugoti ịvairių objektų, o 4504 - atlikti taktines užduotis ${ }^{85}$. Turètais ginklais 1940 m. LŠS galėjo apginkluoti apie 31000 vyrų, nors kariuomenès sandèliuose buvo pakankama šautuvų atsarga ${ }^{86}$. Aprūpinus kariuomenę, buvo galima ir visus šaulius apginkluoti, jų nemobilizuojant. J. Vaičenonis nurodo, kad kariuomené buvo pasirengusi mobilizuoti ir aprūpinti gana gerais

\footnotetext{
79 Vaičenonis J. Lietuvos šaulių sajunga valstybės gynyboje 1935-1940 m. // Lietuvos šauliu sajungos istorijos fragmentai. Red. J. Vaičenonis, S. Dovydaitis. Kaunas, 2002, p. 117.

80 Raštikis S. Ltvykiai ir žmonès. T. 3. Kaunas, 1996, p. 299.

81 Pociūnas A. Lietuvos kariuomenès ginkluotè ir karinė pramonė 1939-1940 m. // Mokslas ir technika. 1993, Nr. 4, p. 30.

821939 m. balandžio 14 d. rašto Nr. 332 priedas. LCVA, f. 929, ap. 3, b. 1024, 1. 23.

83 Statkus V. Lietuvos ginkluotosios pajegos 1918-1940 m. Chicago, 1986, p. 772.

84 Iš 48107 šaulių 19067 buvo I rūšies, 8902 - II rūšies iki 45 m. atsargos kariai, 16448 - kariuomenèje netarnavę iki $45 \mathrm{~m}$. vyrai, 3372 - kariuomenèje tarnavę ir netarnavę daugiau negu $45 \mathrm{~m}$. šauliai. LŠS tuo metu reikejo dar apie 19000 šautuvų, 1000 lengvụjų kulkosvaidžių, $1 \mathrm{mln}$. šovinių ir 5000 granatų: Dèl LŠS vado rašto Nr. 1378. 1940 m. LCVA, f. 929, ap. 5, b. 591, ap. 1. 43; 1940 m. balandžio mẻn. LŠS 22 rinktinèse buvo 872 padalinių vadai, iš jų 404 karininkai, 192 viršilos ir puskarininkiai, 105 grandiniai ir eiliniai, 171 kariuomenejje netarnavęs vyras: LŠS vado 1940 m. balandžio mèn. raportas kariuomenès vadui. LCVA, f. 929, ap. 3, b. 1097, 1. 29-30.

85 Šauliu rinktinėse skaičius: I Kauno - 2 264, V Traku - 1 527, VIII Vilkaviškio - 1 749, IX Seinų - 1 530, XIV Marijampolès - 2 182, XVII Šakių - 1357 ir XIX Alytaus - 2 264: II PD plote esančių šaulių rinktinių panaudojimo plano santrauka. $1940 \mathrm{~m}$. vasario $14 \mathrm{~d}$. LCVA, f. 929 , ap. 3, b. $1154,1.2$.

861940 m. liepos 1 d. kariuomenè turëjo 137500 Mauser ir 10000 kitų sistemų šautuvų ir karabinų. Kariuomenei pagal etatus reikejjo 100825 šautuvų, likutis - 36675 Mauser (bendrai - 46 675) šautuvai: Ginklavimo turto stovio žinios. 1940 m. liepos 1 d. LCVA, f. 3, ap. 1, b. 256, 1. 11.
} 
ginklais 150 000-160 000 karių $^{87}$. Tad Lietuvos ginkluotąsias pajègas būtų sudarę apie 6,2-6,6 \% Didžiosios Lietuvos gyventojų. Kariuomenès dydị lèmé ne atsargos karių, o ginkluotès stygius ${ }^{88}$.

Visi vyrai, Lietuvos Respublikos piliečiai, tinkami tarnauti pagal sveikatos būklę, sulaukę $21 \mathrm{~m}$., turèjo atlikti 18 mèn. trukmès privalomają karo tarnybą. Po jos buvo paliekami atsargoje: I rūšies atsargos kariai - iki kalendorinių metų, kuriais jiems sueis 35-eri, pabaigos, II rūšies - iki metų pabaigos, kuriais jiems sueis 45-eri. Vyrai, kurie kariuomeneje netarnavo arba tarnavo trumpiau nei 6 mèn., bet pagal sveikatos būklę tiko karo tarnybai, iki $45 \mathrm{~m}$. buvo rezerve (apsaugos kariai). Jie taip pat buvo skirstomi ị dvi rūšis: I rūšis - tinkami rikiuotès tarnybai, II - tinkami, bet ne rikiuotès tarnybai ${ }^{89}$. Kaip Lietuvoje kito atsargos karių skaičius, galime spręsti iš pateiktų duomenų: 1926 m. buvo 966 atsargos karininkai ir 74932 atsargos kariai ${ }^{90} .1934 \mathrm{~m}$. 146822 atsargos kariai, iš jų 104102 - I rūšies (1899-1913 m. gim.), 17147 - I rūšies, išleisti „sąlyginių atostogų“, 25573 - II rūšies atsargos kariai ${ }^{11}$, be to, 3200 atsargos ir 1310 tikrosios tarnybos karininku $u^{92}$, o kariuomeneje tarnavo dar apie 17000 karių $^{93} .1937$ m. gruodžio 1 d. duomenimis, ị Lietuvos kariuomenès apskaitą buvo ịtraukti 125604 I rūšies (1902-1918 m. gim.) atsargos kariai $^{94}, 1940$ m. - 122823 (1905-1920 m. gim.) I rūšies, 38623 (1901-1904 m. gim.) ir 37251 (1895-1900 m. gim.) II rūšies atsargos kariai, iš viso $198697 \mathrm{vy-}$ rai (3 priedas) ${ }^{95} .1940 \mathrm{~m}$. rugpjūtị Lietuvoje buvo 3569 atsargos karininkai ${ }^{96}$. Iš viso $1940 \mathrm{~m}$. valstybe turejjo apie 202000 mobilizacijai parengtų atsargos karininkų ir karių. Be to, vertètų pridèti reguliariosios kariuomenès karius (apie 24 000) bei dalị jau anksčiau minètų šaulių - 19 820, kurie nebuvo tarnavę kariuomenejje arba buvo vyresni nei $45 \mathrm{~m}$., todèl nepriklause atsargos

\footnotetext{
87 Bratikas L. Žvilgsnis ị svarbiausius Lietuvos kariuomenès žingsnius // Kardas. 2008, Nr. 6, p. 17. 88

89 Karinès prievolès įstatymas. Vyriausybès žinios. Nr. 538. Kaunas, 1936 m. birželio 30 d., p. 5, 7.

90 Vyriausiojo štabo viršininko $1926 \mathrm{~m}$. liepos $27 \mathrm{~d}$. raportas krašto apsaugos ministrui. LCVA, f. 929 , ap. 3, b. 536, 1. 5, 13 .

91 Atsargos kareivių ataskaitos žinios. 1934 m. LCVA, f. 929, ap. 5, b. 413, 1. 54-56.

92 Vaičenonis J. Lietuvos kariuomenès Vyriausiojo štabo viršininko plk. K. Škirpos Lietuvos kariuomenès vystymo planas // Karo archyvas. T. 22. Vilnius, 2007, p. 393; 399; 411-418.

93 Vaičenonis J. Lietuvos kariuomenès skaičiai 1920-1939 m. // Karo archyvas. T. 17. Vilnius, 2002, p. 166.

94 Vaičenonis J. Lietuvos kariuomenè valstybès politinio gyvenimo verpetuose (1927-1940). Vilnius, 2004, p. 32.

95 Atsargos kareivių žinios. 1940 m. rugpjūčio 1 d. LCVA, f. 929, ap. 5, b. 644, 1. 1-46, 83-88.

96 Karininkų sudèties žinios. 1940 m. rugpjūtis. LCVA, f. 929, ap. 5, b. 646, 1. 24.
} 
karių kategorijai, bet kariškai buvo parengti, taip pat apsaugos rezervą, t. y. kariuomeneje netarnavusius, bet tarnybai tinkamus vyrus.

Nuo 1935 m., kai buvo pradèti šaukti 1914 m. ir vẻliau gimę vyrai, Lietuvos kariuomene pajuto šauktinių stygių, kuris atsirado dėl Pirmojo pasaulinio karo metu susidariusios demografinès „duobès“. Pagal planą kariuomenei kasmet reikèjo 16400 naujokų, o 1914 m. buvo gimęs 18461 berniukas $^{97}, 1915 \mathrm{~m}$. D. Lietuvoje gimè 18843 berniukai, $1916 \mathrm{~m}$. - 16925 , 1917 m. - 15 183, 1918 m. - 15 633, 1919 m. - 19 515, 1920 m. - 22 321, $1921 \mathrm{~m}$. visoje Lietuvoje - 26 736, $1922 \mathrm{~m} .-30149^{98} .1938 \mathrm{~m}$. i kariuomenę buvo pašaukti 12495 vyrai (iš jų 11253 i rikiuotès ir 1242 i ne rikiuotès tarnybą), arba 77,34 \% visų atvykusiųjų (15 991) i karo prievolès komisijas. İ sąrašus 1939 m. buvo įrašytas 18471 vyras, tačiau $2480(13,09 \%)$ iš jų neatvyko arba buvo išbraukti iš sąrašų ${ }^{99}$. Remiantis kitais duomenimis, 1939 m. ì kariuomenę buvo pašaukta 11730 vyrų (iš jų 9959 ị rikiuotés ir 1771 i ne rikiuotès tarnybą), arba 79,48 \% visų atvykusiujų (14 745) i karo prievolès komisijas. I sąrašus 1939 m. buvo įrašyti 17695 vyrai, tačiau 2950 $(16,67 \%)$ iš jų neatvyko arba buvo išbraukti iš sąrašų ${ }^{100}$. Nors ir ankstesniais metais ị kariuomenę buvo šaukiama ganètinai mažai vyrų ${ }^{101}, 1940 \mathrm{~m}$. planuota pašaukti tik 13000 naujokų. Todèl kariuomenèje buvo daug pakartotinai pašauktų karių, kai kurie jų tarnavo jau trečius metus. Nuolatinio apie 6000 , arba $25 \%$, šauktinių karių trūkumo turëjo nebesijausti 1942-1943 m. pradejus šaukti 1921-1922 m. gimusiuosius ${ }^{102} .1938-1939$ m. Lietuvos kariuomenejje tikrosios karo tarnybos karių (šauktinių) buvo apie 18 000-19 $000^{103}$, nors pagal tuometę etatų ir komplektavimo tvarką turëjo

\footnotetext{
97 Dabartinès kariuomenès taikos meto būklè. 1940 m kovo 15 d. LCVA, f. 929, ap. 5, b. 591, 1 .

98 Lietuvos statistikos metraštis 1924-1926 m. Kaunas, 1927, p. 30.

991938 m. naujokų ėmimo apyskaita. LCVA, f. 929, ap. 5, b. 529, 1. 1-2.

1001939 m. naujoku èmimo apyskaita. LCVA, f. 929, ap. 5, b. 557, 1. 1-2.

1011929 m. ị kariuomenę buvo pašaukti 8676 vyrai, 1930 m. - 10 597, 1931 m. - 10 119: Žinios ịkadruotų naujokų, 1933 m. kovo 8 d. LCVA, f. 929, ap. 5, b. 393, 1. 7; 1932 m. - 10861 vyras: 1932 m. ị kariuomenę priimtų naujokų žinios, 1933 m. kovo 7 d. LCVA, f. 929, ap. 5, b. 393, 1. 27; 1933 m. šauktinių sąrašuose buvo 28784 vyrai, pavasarinio šaukimo metu paimti 5 508, o rudenị - 5500 jaunuolių: Vidaus reikalų ministerija. 1933 m. liepos 29 d. LCVA, f. 929, ap. 5, b. 393, 1. 208; 1933 m. pavasario naujokų įkadravimo suskirstymas. $L C V A$, f. 929, ap. 5, b. 393, 1. 61; 1933 m. rudens naujoku ikadravimo suskirstymas. $L C V A$, f. 929, ap. 5, b. 393, 1. 210.

${ }^{102}$ Kariuomenės štabo III skyriaus samprotavimai klaipėdiečių karo prievolès reikalu. $L C V A$, f. 929, ap. 5, b. 562, 1. 9-11; Dabartinès kariuomenès taikos meto būklè, 1940 m. kovo 15 d. $L C V A$, f. 929 , ap. 5, b. 591, 1. 21.
}

${ }^{103}$ Vaičenonis J. Lietuvos kariuomenès skaičiai 1920-1939 m. // Karo archyvas. T. 17. Vilnius, 2002, p. 170-171. 
būti organizuoti 3 šaukimai ir pašaukta apie 24600 šauktinių. Dėl to buvo neįmanoma iki galo sukomplektuoti karinių dalinių ir tinkamai parengti karių. Kartu valstybė kasmet sutaupydavo apie 7,2 mln. Lt, nes vieną karị išlaikyti per mėnesi kainavo apie 100, per metus - $1200 \mathrm{Lt}$.

XX a. ketvirtojo dešimtmečio pabaigoje Lietuva turèjo pakankamai daug kariškai parengtų žmonių: atsargos karininkų, I ir II rūšies atsargos karių, nemobilizuojamų rikiuotès šaulių ir reguliariosios kariuomenès karių, iš viso apie 246000 vyrų, kurių būtų pakakę planuojamiems daliniams suformuoti ir dar daug būtų likę jiems papildyti. Tiek kovotojų būtų užtekę ir gen. št. plk. Kazio Škirpos plane ateityje siūlytoms 12 pėstininkų divizijų suburti ${ }^{104}$, tačiau Lietuva tokiam divizijų skaičiui dar stokojo ginkluotés, ypač sunkiosios.

\section{LIETUVOS FINANSŲ IR ŪKIO MOBILIZAVIMO KARO ATVEJU PERSPEKTYVOS}

Eventualaus karo su Lenkija atveju Lietuva neišvengiamai turejo mobilizuoti savo kariuomenę ir ūkį, taip pat skirti pakankamai lèšų mobilizuotoms pajëgoms išlaikyti ir visokeriopai aprūpinti. Visuotinè karo prievolè ekonomiškai prilygsta ūkio ịtraukimui ị karą. Individai ir ūkio subjektai, ją atlikdami, atsitraukia nuo gamybos: kuo didesnis skaičius asmenų atlieka karo prievolę, tuo labiau smunka ūkis, tuo sunkiau patenkinti poreikius, nes mažèja gamy$\mathrm{ba}^{105}$. Žinoma, agrarinei tarpukario Lietuvai, kurios žemès ūkyje buvo apie 300000 darbininkų perteklius ${ }^{106}$, tai galima taikyti tik su tam tikra išlyga. Anot XX a. D. Britanijos karybos teoretiko gen. mjr. Johno F. C. Fullerio, „pirmoji karo vado pareiga - įvertinti ekonominị ir finansinị krašto pajègumą “107.

Aptariant karo biudžetą, derètų atskirti lèšas, reikalingas kariuomenei mobilizuoti ir karo veiksmams finansuoti. Pirmuoju atveju lèšos turètu būti numatytos iš anksto, antruoju - skiriamos ir naudojamos pagal porei$\mathrm{kị}^{108} .1935 \mathrm{~m}$. Intendantūros prièmimo komisijos pirmininko plk. ltn. Kazio Ramanausko parengtame slaptame dokumente Lietuvos valstybés finan-

\footnotetext{
${ }^{104}$ Vaičenonis J. Lietuvos kariuomenès Vyriausiojo štabo viršininko plk. K. Škirpos Lietuvos kariuomenès vystymo planas // Karo archyvas. T. 21. Vilnius, 2006, p. 386, 411, 422.

${ }^{105}$ Acus-Acukas J. Karo ekonomikos bruožai. Mūsų žinynas. 1938, Nr. 3, p. 403.

${ }^{106}$ Pakštas K. Baltijos respublikų politinè geografija // Lietuvos geopolitika. Sud. S. Vaitiekūnas. Vilnius, 1991, p. 42.

107 Šimkus A. Valstybė ir ekonominiai klausimai taikos ir karo metu. Mūsų žinynas. 1936, Nr. 140, p. 408.

${ }^{108}$ Bukevičius R. Karo meto biudžetas. Mūsų žinynas. 1936, Nr. 130, p. 61-62.
} 
su mobilizacijos planas karo metui, atlikus Belgijos, Serbijos ir Rumunijos kariuomenių išlaikymo Pirmojo pasaulinio karo metu ir karo finansavimo problemų analizę, konstatuota, kad „šių dienų galiūnų grumtynèse maža valstybe negali kariauti be stipresniujų pagalbos, bet ir jų padedama lengvai gali netekti didesnès dalies arba ir visos savo teritorijos. Lietuva yra maža valstybè, kuriai graso du galingi kaimynai: Vokietija ir Lenkija. Apie atskirą Lietuvos karą su Vokietija ar Lenkija niekas rimtai negalvoja“109. Buvo teigiama, kad kilęs ginkluotas konfliktas peraugtų į visos Europos, o gal net ir i pasaulinị karą. Tokiu atveju tikètasi, kad Lietuva kariaus ne viena ir eventualios kaimynès agresorès visų savo pajëgų prieš Lietuvą nukreipti negalès, tačiau, pasiremiant ankstesnių karų patirtimi, didelę reikšmę turès didžiụjų valstybių kariuomenių manevravimas ir pajègų permetimo galimybe் $\dot{e}^{110}$.

Po Pirmojo pasaulinio karo nè viena Europos valstybè nesistengè sukaupti tokị kiekị atsargų, kad užtektų visam galimam karui. Manyta, kad valstybẻ karui yra pasirengusi, jei turi sukaupusi atsargų, kurių pakaks mobilizacijai atlikti ir pajëgoms išlaikyti, kol pradès veikti mobilizuota krašto pramonè ir sugebès aprūpinti pajègas. Lietuvos karo pramonè nebuvo išplètota, todèl konstatuota, kad „mūsų valstybę pasirengusią karui teoriniai reikètų laikyti: 1) kada mūsų šalyje gaminamų reikmenų turèsime tokias atsargas, kurių pakaks mobilizuotai kariuomenei, iki tų išteklių karo meto pareikalavimą galès patenkinti mobilizuota krašto pramonè, ir 2) kada iš užsienių gaunamų išteklių turèsime tokias atsargas, kurių pakaks mobilizuotai kariuomenei, iki bus sutvarkytas tų išteklių normalus tiekimas iš tų šalių, iš kurių juos numatoma gauti.“111

Tarpukariu Lietuvos Respublikoje buvo priimta keletas ịstatymų, kurie reguliavo kariuomenès aprūpinimo, transportavimo, rekvizicijų iš gyventojų surinkimo karo metu klausimus. 1933 m. buvo priimtas naujas Žyginiu arkliu istatymas $^{112}, 1935 \mathrm{~m}$. - Butams ir trobesiams sekvestruoti kariuomenés reikalams istatymas, kuriame numatyta, kad karo komendanto įsakymu visi pastatai, išskyrus maldos namus, ligonines ir mokyklas mokslo metų laiku, gali būti naudojami kariuomenès reikmèms ${ }^{113}$. Viešaisiais keliais judëjimo istatyme buvo numatyta, kad kariuomenè prireikus gali apriboti arba sustab-

\footnotetext{
${ }^{109}$ Lietuvos valstybès finansų mobilizacijos planas karo metui, 1935 m. LCVA, f. 929, ap. 5, b. 663 , ap.1. 2 .

110 Ten pat, 1. 2-3.

${ }^{111}$ Lietuvos valstybès finansų mobilizacijos planas karo metui, 1935 m. LCVA, f. 929, ap. 5, b. $663,1.4$.

112 Žyginių arklių įstatymas // Vyriausybès žinios. Nr. 431, 1933 m. gruodžio 22 d., p. 1-2.

${ }^{113}$ Butams ir trobesiams sekvestruoti kariuomenès reikalams įstatymas// Vyriausybès žinios. Nr. 469, 1935 m. vasario 9 d., p. 1.
} 
dyti judejjimą keliais ${ }^{114}$. Labai svarbus kariuomenès išlaikymo ir aprūpinimo karo metu klausimais buvo Natūraliniu karo prievoliu įstatymas ${ }^{115} .1936 \mathrm{~m}$. buvo priimtos Kariuomenès reikalams susisiekimo priemonems tikrinti ir registruoti taisykle s ${ }^{116}$. Taigi $1935-1936 \mathrm{~m}$. buvo patobulinti ịstatymai, kurie turèjo reglamentuoti kariuomenès veiklą, susijusią su civiliais, ir užtikrinti jos aprūpinimą karo atveju savo teritorijoje.

Remiantis 1936 m. patvirtinta direktyva, mobilizuojama kariuomenè lèšomis turèjo būti aprūpinta vietose, skirtus pinigus gauti Lietuvos banko skyriuose $^{117}$. Buvo apskaičiuota, kad mobilizacija gali kainuoti apie $42 \mathrm{mln}$. $\mathrm{Lt}^{118}$. $1938 \mathrm{~m}$. buvo nurodyta, kad mobilizacijos atveju dalių vadams šio banko skyriuose skirtos lèšos turi būti išduodamos ir ne darbo metu, dalinių vadams su banko skyrių viršininkais susitarus iš anksto ${ }^{119} .1938 \mathrm{~m}$. lapkričio $30 \mathrm{~d}$. šiame banke saugota 49,3 mln. Lt indèlių (19,1 mln. Lt privačių ir 30,2 mln. Lt valstybès), iš viso visuose bankuose buvo $301,9 \mathrm{mln}$. Lt indèlių. Lietuvos bankas turejjo 66,441 mln. Lt aukso, 15,156 mln. Lt sidabro ir 3,625 mln. Lt užsienio valiutos atsargu ${ }^{120}$. $1939 \mathrm{~m}$. rugpjūčio $31 \mathrm{~d}$. jame buvo $25,434 \mathrm{mln}$. Lt, o visuose bankuose - 204,574 mln. Lt indèlių. Lietuvos bankas turëjo sukaupęs 60,271 mln. Lt aukso, 10,254 mln. Lt sidabro, 6,022 mln. Lt užsienio valiutos atsargų ${ }^{121}$, pakankamai, kad galètų finansuoti mobilizaciją ir kariuomenę pirmą karo mėnesį. Buvo numatyti keturi galimi karo metu reikalingų lèšu šaltiniai: 1) mokesčiai, 2) vidaus paskola, 3) užsienio paskola ir 4) papildomos popierinių pinigų emisijos spausdinimas. Konstatuota, kad tik jas kompleksiškai naudojant galima būtų išspręsti eventualaus karo finansavimo problemą, nes kiekvienas iš minètų šaltinių turèjo savo trūkumų, buvo ribotas arba rizikingas. Priešui greitai okupavus dali Lietuvos teritorijos, pirmi du šaltiniai mokesčiai ir vidaus paskola - būtų „nebepasiekiami“. Galimybė gauti užsienio paskolą priklausė nuo geopolitinių aplinkybių ir sajungininkų malonės, o nepadengtų popierinių pinigų papildomos nesaikingos emisijos būtų sukèlusios

\footnotetext{
${ }^{114}$ Viešaisiais keliais judejjimo įstatymas // Vyriausybès žinios. Nr. 431, 1935 m. balandžio 27 d., p. 1 .

115 Natūraliniu karo prievolių įstatymas// Vyriausybès žinios. Nr. 513, 1935 m. gruodžio 6 d., p. $1-2$.

${ }^{116}$ Kariuomenès reikalams susisiekimo priemonèms tikrinti ir registruoti taisyklès// Vyriausybès žinios. Nr. 528, 1936 m. kovo 28 d., p. 3-6.

${ }^{117}$ Direktyva mobilizuojamą kariuomenę pinigais aprūpinti ir vykdyti. $1936 \mathrm{~m}$. sausio $28 \mathrm{~d}$. $L C V A$, f. 506, ap. 1, b. 186, 1. 1.

${ }^{118}$ Lietuvos valstybès finansų mobilizacijos planas karo metui. 1935 m. LCVA, f. 929, ap. 5, b. $663,1.13-13$ ap. 1 .

${ }^{119}$ Kariuomenès štabo III skyrius. 1938 m. kovo 19 d. LCVA, f. 929, ap. 5, b. 460, 1. 163.

${ }^{120}$ Statistikos biuletenis. 1939, Nr. 1, p. 30.

${ }^{121}$ Ten pat, Nr. 9, p. 384.
} 
infliaciją. Buvo siūloma krizès atveju riboti bankų išmokamų grynųjų pinigų sumas ir net karinio konflikto pradžioje organizuoti privalomą vidaus paskolą ${ }^{122}$. Kai 1939 m. kovo 22 d. Klaipèdos kraštą perdavus Vokietijai kilo indèlininkų panika, Finansų ministerija skubiai įvedė grynųjų pinigų išmokẻjimo apribojimus - leido per $3 \mathrm{~d}$. išmokèti ne daugiau kaip $50 \mathrm{Lt}$, vèliau - ne daugiau kaip $200 \mathrm{Lt}^{123}$. Taigi kompleksinis problemos sprendimas atrodė racionalus, nes mokesčių ir vidaus paskolos lëšas buvo galima kaupti tik pirmosiomis karo dienomis. Užsienio pagalba galejjo būti ne tik piniginè paskola, bet ir ginklai, amunicija. Vèlesni grynụjų pinigų stygių krašto viduje iš dalies ir saikingai buvo galima dengti leidžiant mažo nominalo banknotų emisijas ${ }^{124}$.

Minètoje plk. ltn. K. Ramanausko parengtoje direktyvoje teigiama, kad mažujų valstybių vaidmuo dideliame kare yra antraeilis, jų likimas priklauso nuo didžiųų sajungininkų sèkmès ir jų „moralès“, abejota, ar SSRS, laimëjusi karą (jei Lietuva būtų buvusi jos sajungininkė), su Lietuva pasielgtų taip, kaip Antantè su Belgija ir Serbija po Pirmojo pasaulinio karo. Taip pat konstatuota, kad mažos valstybès negali dalyvauti ginklavimosi varžybose, o Lietuva ateityje į karą turès stoti remdamasi tais pajègumais, kokius iki to laiko sugebès parengti ir mobilizuoti ${ }^{125}$.

XX a. ketvirtojo dešimtmečio antros pusès Lietuvos mobilizuotą kariuomenę turẻjo sudaryti apie 125000 vyrų, iš jų 5000 karininkų, 19218 viršilu ir puskarininkių, 100782 grandiniai ir eiliniai ${ }^{126}$. Jiems apginkluoti $1939 \mathrm{~m}$. rugsejjo $1 \mathrm{~d}$. Lietuvos kariuomenès daliniuose ir sandèliuose buvo 131338 šautuvai ir karabinai, 805 sunkieji ir 3696 lengvieji kulkosvaidžiai, 549 ịvairūs artilerijos pabūklai, 54 tankai ir šarvuočiai, 115 karo lèktuvų ir kt. ${ }^{127}$

\footnotetext{
${ }^{122}$ Lietuvos valstybès finansų mobilizacijos planas karo metui. 1935 m. LCVA, f. 929, ap. 5, b. $663,1.22$.
}

${ }^{123}$ Vaskela G. Lietuva 1939-1940 metais. Kursas $i$ valstybès reguliuojama ekonomika. Vilnius, 2002, p. 24.

${ }^{124}$ Lietuvos valstybès finansų mobilizacijos planas karo metui. 1935 m. LCVA, f. 929, ap. 5, b. $663,1.22$.

${ }^{125}$ Ten pat, ap. 1. 10-11, ap.1. 21.

${ }^{126}$ KAM mobilizacijos vykdymo ir vieno karo mėnesio išlaidų sąmata. $L C V A$, f. 1, ap. 1, b. 408, 1. 124-127.

${ }^{127}$ Lietuvos kariuomenè turèjo: pistoletų - 11 801, kardų - 8 461, 89,24 mln. - šovinių, granatų - 81 388, 81,4 mm Brandt 1934 m. minosvaidžių - 102, minosvaidžių minų - $33295,20 \mathrm{~mm}$ Oerlikon pabūklų - 151, 2 cm Flak 30 pabūklų - 75, jų šaudmenų - 187635,75 mm Schneider $1897 \mathrm{~m}$. patrankų - 108, $105 \mathrm{~mm}$ Schneider $1934 \mathrm{~m}$. haubicų - 70, Putilov $1902 \mathrm{~m}$. patranku 19, Vickers-Amstrong zenitinių pabūklų - 9, 83,8 mm Mk. IV patrankų - 8, 83,8 mm Mk. II patrankų - 4, $155 \mathrm{~mm}$ Schneider Mle 1917 haubicu - 2, $105 \mathrm{~mm} 10 \mathrm{~cm} \mathrm{K17}$ patrankų - 1, ivairių artilerijos sviedinių - 188 305; Vickers Carden Loyd lengvujų tankų - 32, Renault FT-17 lengvuju tankų - 12, Landsverk 181-29/34 šarvuočių - 6, Ehrhardt/Daimler Behelftswagen šarvuočių - 4: Ginklavimo viršininkui apginklavimo žinios. 1939 m. rugsejjo 1 d. LCVA, f. 3, ap. 1, b. 256, 1. 7. 


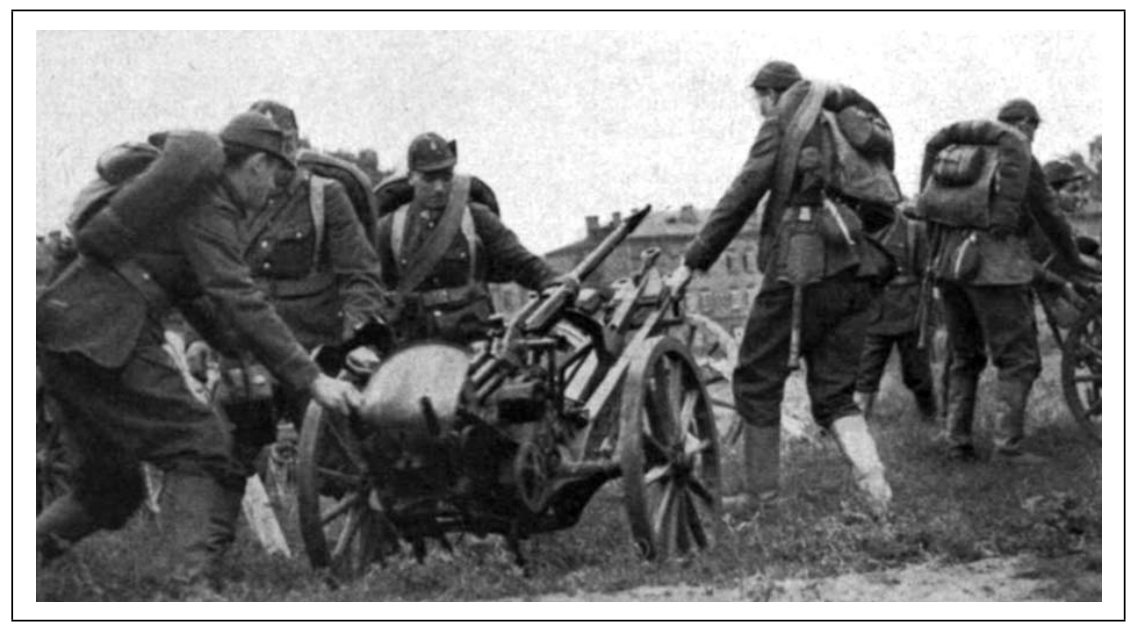

Lietuvos kariuomenès kariai prie prieštankinio 20 mm pabūklo Oerlikon. Kardas, $1940 \mathrm{~m}$.

Kariuomenès sandèliuose buvo sukaupta mobilizacinè ginklų ir aprangos atsarga 120400 karių. Turèdama tokius ginklų ir amunicijos išteklius Lietuvos kariuomenè nenutrūkstamai kovos veiksmus galejo tęsti dvi savaites ${ }^{128}$. Minèto dydžio kariuomenès mobilizacija, įskaitant atlygi gyventojams už rekvizuotas priemones, galejo kainuoti apie 30,1 mln. Lt, o vieno mėnesio karo išlaidos - sudaryti apie 13,1 mln. Lt. Taigi mobilizuoti kariuomenę ir mėnesi ją išlaikyti turejo kainuoti apie 43,2 mln. Lt. Tačiau daugiau nei pusę šios sumos (22,1 mln. Lt) sudaré lëšos, numatytos sumokèti gyventojams už 32780 rekvizuotų arklių, dar 2,1 mln. Lt - už vežimus. Karių maitinimo ir arklių išlaikymo per mènesị išlaidos siekė $8,2 \mathrm{mln}$. Lt (vieno kario maitinimui per dieną buvo numatyta skirti 1,2 Lt, arklio pašarui - apie 20-21 ct), o mobilizuotos kariuomenès algoms reikejjo atseikèti apie $8,6 \mathrm{mln}$. Lt (įskaitant mobilizacijos kompensacijas karininkams ir pirmo mèn. algą). Likusi 2,2 mln. Lt suma buvo numatyta arklių nuostoliams kompensuoti, gurguolès vežimų eksploatacijos išlaidoms padengti, transportui, ūkiui ir kanceliarijai išlaikyti ${ }^{129}$. Darytina prielaida, kad būtinomis laikytinos tik maitinimo ir ūkio išlaidos, t. y. 10,4 mln. Lt, o algų mokẻjimo avansu tvarka galejjo būti pakoreguota. Išmokant visas algas, 125000 kariuomenès mobilizacija ir išlaikymas pirmą

\footnotetext{
${ }^{128}$ Surgailis G. Lietuvos kariuomene 1918-1998. Vilnius, 1998, p. 29.

${ }^{129}$ KAM mobilizacijos vykdymo ir vieno karo mènesio išlaidų sąmata. $L C V A$, f. 1 , ap. 1, b. 408, 1. 124-127.
} 
mėnesị turèjo kainuoti apie $19 \mathrm{mln}$. Lt, o vèliau - maždaug po $13 \mathrm{mln}$. Lt kas ménesị. Be to, ir karinè vadovybe konstatavo, kad dèl léšų stokos ir valiutos pastovumo vienu metu išleisti didelę pinigų sumą - neracionalu, todèl siūlè iš karto sumokèti tik $25 \%$ rekvizuoto civilių turto vertès, o likusią sumą dalimis vèliau $^{130}$. Taigi D. Lietuvai, mokant tik $25 \%$ rekvizuoto turto vertès, būtų reikèję turèti 7,3 mln. Lt, Klaipėdos karštui, mokant visą sumą, nes tai numaté Klaipėdos konvencija, - apie 2,1 mln. Lt, iš viso - 9,4 mln. $\mathrm{Lt}^{131}$.

Buvo apskaičiuota, kad karo mėnuo Lietuvai galejo kainuoti apie $62,67 \mathrm{mln}$. Lt, o visą valstybės aparatą išlaikyti (be KAM) - dar apie 16,85 mln. Lt, taigi ménesiui reikejjo turèti 79,52 mln. Lt, metams - 954,24 mln. Lt. Lietuva, be paramos iš šalies, pirkdama ginklus ir amuniciją užsienyje, pati galejo finansuoti maždaug vieno mènesio karo išlaidas ${ }^{132}$. Apie $8 \mathrm{mln}$. Lt minètos sumos kas mènesị būtų reikèję sumokèti gyventojams už rekvizuotus maisto produktus ir transporto priemones ${ }^{133} .1935 \mathrm{~m}$. teigta, kad mobilizacinio turto trūkumui likviduoti reikejjo $215 \mathrm{mln}$. Lt, 19,55 mln. Lt šios sumos buvo ịvardyta kaip „nenumatytos išlaidos“134. Žinant, kad 1935 m. buvo pradètas igyvendinti jau minètas kariuomenès apginklavimo planas, iki $1941 \mathrm{~m}$. pabaigos trūkumai turèjo būti pašalinti.

Karo metu visada aktualu pakankamai aprūpinti kariuomenę maistu. Tuo tikslu dar taikos metais buvo kaupiamos atsargos, bet karo atveju pagrindiniai ištekliai turejjo būti surenkami vietose. Šiuo klausimu turejo rūpintis Kariuomenès intendantūra. Iš gyventojų maisto produktai turejjo būti superkami arba rekvizuojami, išduodant vèlesnio atsiskaitymo čekius. Svarbu, kad krašte būtų pakankamai maisto ir pašarų išteklių. Planuojamai 125000 kariuomenei maitinti per mènesį reikejjo $938 \mathrm{t}$ kiaulienos, $225 \mathrm{t}$ sviesto (riebalų), $1500 \mathrm{t}$ bulvių, $94 \mathrm{t}$ druskos, $112 \mathrm{t}$ cukraus, $19 \mathrm{t}$ miežinès kavos $^{135}, 2800 \mathrm{t}$ rugių, $150 \mathrm{t}$ kviečių, $540 \mathrm{t}$ miežių, $380 \mathrm{t}$ žirnių, $6100 \mathrm{t}$ avižų.

\footnotetext{
${ }^{130}$ Kariuomenès tiekimo valdyba 1936 m. vasario 28 d. Kariuomenès štabo viršininkui. LCVA, f. 1, ap. ą, 408, 1. 57.

${ }^{131}$ Už mobilizacijos metu vykdytinas rekvizicijas atlyginti KAM išlaidų sąmata, $1936 \mathrm{~m}$. kovo 16 d. $L C V A$, f. 1, ap. 1, b. $408,1.61$.

${ }^{132}$ Lietuvos valstybès finansų mobilizacijos planas karo metui, 1935 m. LCVA, f. 929, ap. 5, b. 663 , ap. 1. $23,1.25$.

${ }^{133}$ KAM Tiekimo valdyba 1935 m. gruodžio 5 d. finansų ministrui. $L C V A$, f. 1, ap. 1, b. 408, 1. 8 . ${ }^{134}$ Bendroji KAM karo išlaidų santrauka. LCVA, f. 929, ap. 5, b. 663, 1. 29.

${ }^{135}$ Per mènesi 200000 karių kariuomenès maitinimui reikèjo 4530 t rugių, $240 \mathrm{t}$ kviečių, $1500 \mathrm{t}$ kiaulienos, $360 \mathrm{t}$ sviesto, $600 \mathrm{t}$ kruopų, $180 \mathrm{t}$ kvietinių miltų, $2400 \mathrm{t}$ bulvių, $150 \mathrm{t}$ druskos, 180 t cukraus (1933 m. Lietuvoje buvo pagaminta $12684 \mathrm{t}$ cukraus), $30 \mathrm{t}$ miežinès kavos: Baltrušis J. Maisto produktų ištekliai Lietuvoje karo perspektyvoje. Mūsų žinynas. 1935, t. 28, Nr. 122, p. 451, 462-463.
} 
1936 m. Intendantūros atsargas sudarè apie $1000 \mathrm{t}$ rugių, $200 \mathrm{t}$ kviečių, $50 \mathrm{t}$ miežių, $200 \mathrm{t}$ žirnių ir $500 \mathrm{t}$ avižų, iš viso apie $2000 \mathrm{t}$ javų (už $350000 \mathrm{Lt}$ ), nors mobilizuotai kariuomenei maitinti (maistui ir pašarui) per mėnesi reikejo apie $10000 \mathrm{t}$ javu $^{136} .1939 \mathrm{~m}$. kariuomenès sandèliuose nuolat buvo saugoma $1400 \mathrm{t}$ rugių, $175 \mathrm{t}$ kviečių, $280 \mathrm{t}$ miežių ir $150 \mathrm{t}$ žirnių. Šiu atsargų mobilizuotai kariuomenei turejjo užtekti maždaug 15 dienų ${ }^{137}$. Karo atveju neabejotinai kariuomenès aprūpinimo našta turejjo užgulti ir pramonès įmones, ypač valstybines ir kooperacines. $1939 \mathrm{~m}$. buvo numatyta, kad $\mathrm{AB}$ „Maistas“ nuolatos savo skerdyklose turi laikyti $37 \mathrm{t}$ jautienos ir avienos arba $20 \mathrm{t}$ kiaulienos ir prireikus skubiai išduoti priedangos daliniams. Karo atveju ši bendrovė Kauno ir Panevéžio fabrikuose turejjo pagaminti ir kariuomenei patiekti apie 650000 vnt. 300 g mėsos konservų děžučių ${ }^{138}$. $1938 \mathrm{~m}$. Lietuvoje visų grūdinių kultūrų derlius buvo apie $1,8 \mathrm{mln}$. t, bulvių 2,118 mln. t, metų pabaigoje šalyje buvo 557540 arklių, 1192840 raguočių, 1249470 kiaulių, 618980 avių, 4,85 mln. naminių paukščių ${ }^{139}$. Mobilizuota kariuomenè lengvai iš vietos ištekliu galëjo būti aprūpinta nuo rugiapjūtès iki pavasario sejjos, tačiau po sejjos iki derliaus nuėmimo galejo kilti sunkumų, nes ūkininkai paprastai pasilikdavo maisto produktų atsargų tik savo poreikiams tenkinti ${ }^{140}$.

Kariuomenès aprūpinimo ekipuote mobilizacijos atveju klausimas iš dalies buvo išspręstas. Tai rodo $1939 \mathrm{~m}$. rugsèjo mobilizacija, nors ir ne visi kariai gavo tinkamo dydžio uniformas, stokojo tam tikrų ekipuotès elemen$\operatorname{tuc}^{141} .1936$ m. mobilizuotai kariuomenei trūko 40000 aprangos komplektų, iki 1941 m. planuota parūpinti trūkstamų milinių, o kitų drabužių stokos problemą išspręsti įpareigojant karius dèvèti savo aprangą, už kurią būtų jiems

\footnotetext{
${ }^{136}$ Karo tiekimo viršininkas 1936 m. lapkričio 18 d. kariuomenès vadui. $L C V A$, f. 1 , ap. 1 , b. $385,1.79$.

${ }^{137}$ Mobilizacijos dalies 1939 m. kovo 20 d. raportas kariuomenès tiekimo viršininkui. LCVA, f. 506 , ap. 1, b. $209,1.43$.

${ }^{138} \mathrm{AB}$ „Maistas“ privalèjo nuolatos turèti ne tik neliečiamą kieki mèsos, bet ir $55 \mathrm{t}$ skardos konservų děžutėms gaminti. Pati kariuomenė $1939 \mathrm{~m}$. taip pat turejo sukaupusi apie 650000 konservų dėžučių - 1/3 daliniuose ir 2/3 Intendantūros sandèliuose: Kariuomenès intendantūros 1939 m. kovo 27 d. raportas kariuomenès tiekimo viršininkui. $L C V A$, f. 506, ap. 1, b. 209, 1. 46.

${ }^{139}$ Apie 265000 t grūdų reikejjo sèklai, $610000 \mathrm{t}$ - maistui, $740000 \mathrm{t}$ - pašarui, o apie $164500 \mathrm{t}$ liko eksportui. Statistikos biuletenis. Kaunas, 1939 m., Nr. 1, p. 1, 3.

${ }^{140}$ Tiekimo viršininkas 1937 m. sausio 12 d. kariuomenès intendantui. LCVA, f. 1, ap. 1, b. 385, 1. 64 .

${ }^{141} 1939$ m. rugsèjo mènesio mobilizacijos reliacija. 1940 m. gegužès 4 d. LCVA, f. 929, ap. 5, b. 547 , ap. 1.9 .
} 
atlyginta $^{142} .1937 \mathrm{~m}$. konstatuota, kad mobilizacijai reikia parengti 102000 uniformų komplektų, tačiau, jų trūkstant, nurodyta PAB karius aprūpinti tik kepuremis, diržais, šovininemis, o prireikus - ir batais. Nuosavus drabužius galëjo dèvèti užnugario: ginklavimo, intendantūros, karo sanitarijos, karo veterinarijos, meteorologijos tarnybų, gurguolès ir karo teismo kariai ${ }^{143}$.

$\mathrm{XX}$ a. ketvirtajame dešimtmetyje kilus ginkluotam konfliktui Lietuva buvo pajègi finansuoti savo kariuomenès mobilizaciją ir poreikius pirmaji karo mènesį, karo veiksmams užsitęsus, buvo planuojama skolintis užsienyje. Kariuomenès aprūpinimas maistu ir pašaru galèjo būti užtikrintas remiantis vietos ištekliais, nors vasarą vietose galejo kilti maisto produktų surinkimo sunkumų.

\section{OPERACIJU PLANAS NR. 3 „L“ - „LENKIJA“}

1937 m. Lietuvos kariuomenès parengti operacijų planai Nr. 1 „V“ („Vokietija“), Nr. 3 „L“ („Lenkija“) ir Nr. 2 „V+L“ („Lenkija + Vokietija“) praktiškai galiojo iki pat Lietuvos okupacijos ir aneksijos 1940 m. 1939 m. pabaigoje "V" planas buvo pakoreguotas atsižvelgiant i i RA bazių išdėstymą, o „L“ virto „R“planu, tik „V+L“ planas 1939 m. spalio 10 d. Lietuvai ir SSRS sudarius savitarpio pagalbos sutartị pasidare nebeaktualus. Pagal 1937 m. kovo 31 d. patvirtintą operacijų planą Nr. 3 „L“ buvo numatyta, kad Lenkija gali pulti (4 priedas):

1. siekdama okupuoti ir aneksuoti Lietuvą ir taip padidinti savo teritoriją;

2. siekdama išsikovoti naują prièjimą prie jūros;

3. strateginiais ir kariniais sumetimais, nes karo su SSRS atveju šiaurinis lenkų sparnas būtų buvęs nesaugus iš užnugario dẻl galimo Lietuvos puolimo.

Be to, buvo spejjama, kad dèl strateginių priežasčiu anksčiau minètu tikslų siekị gali inspiruoti prasidèjęs karas su SSRS arba Vokietija.

Kilus konfliktui pagrindinès Lenkijos puolimo prieš Lietuvą kryptys galèjo būti šios: 1) Suvalkai-Marijampolè, nes puldami šia kryptimi lenkai galejjo greitai užimti Suvalkiją, tačiau, priartèję prie Kauno tvirtovès ir Nemuno žemupio, būtų turèję įveikti atkaklesnị Lietuvos kariuomenès pasipriešinimą; 2) Vilnius-Vievis-Kaišiadorys, nes šia kryptimi iš Vilniaus i Lietuvą buvo nutiestas vienintelis geležinkelis, todèl Lenkijos kariuomenei turèjo strateginę reikšmę dèl tiekimo. Lietuvos kariuomenė turèjo gintis Kauno tvirtovés ir Neries upés ruože; taip pat buvo svarbu išlaikyti Jonavos tiltus per Nerị; 3) Vilnius-Śirvintos-Kèdainiai - puolimas šia kryptimi galejjo užkirsti Lietuvos kariuomenei atsitraukimo iš Kauno kelią, tačiau len-

\footnotetext{
${ }^{142}$ Raportas kariuomenès vadui. 1936 m. gruodžio 17 d. LCVA, f. 1, ap. 1, b. 385, 1. 69.

${ }^{143}$ Kariuomenès štabo III skyriaus 1937 m. gegužès 24 d. raportas tiekimo viršininkui. LCVA, f. 1 , ap. 1, b. $385,1.49$.
} 
kai turejjo įveikti ginamas Šventosios ir Nevėžio upes: didelių lenkų pajėgu puolimas šia kryptimi galèjo perskirti Lietuvos kariuomenę ị dvi dalis. Jis buvo nukreiptas i pagrindinių Lietuvos pajègų sutelkimo rajoną. Ši lenkų puolimo kryptis lietuvių kariuomenei buvo pati pavojingiausia; 4) PabradéMolètai - veržiantis šia kryptimi galima buvo patekti i Lietuvos kariuomenès užnugarị, tačiau jos štabas numatè, kad dèl būtinybės įveikti didesnius atstumus lenkų puolimas bus silpnas ir šiaurinị sparną dengti turès padėti kavalerija. Taip pat buvo galima laukti Lenkijos kariuomenès desanto Baltijos pajūryje. Tačiau dèl atstumo ir ribotų laivyno pajëgų lenkų desantas negalèjo būti veiksmingas iš anksto nepasirengus tokiai operacijai.

Lietuvos kariuomenès karinių veiksmų efektyvumas labai priklausė nuo mobilizacijos sèkmès. Kariuomenès štabo manymu, pasienio apsaugos batalionų mobilizacija turejjo prasidèti prevenciškai - iš karto kilus konflikto pavojui. Sèkmingai visos kariuomenès mobilizacijai reikèjo 2-3 dienų. Sienai dengti buvo skirta Marijampolés priedangos rinktinè (toliau - PR) - 9-ojo PP du batalionai, Kaišiadorių PR - 9-ojo PP batalionas iš Vilkaviškio ir artilerijos baterija iš Marijampolès, Alytaus PR - 2-asis ulonų KP, Ukmergès PR - 1-asis PP. Molètų barą turèjo dengti 1-asis husarų KP, tačiau pulkui pasiekti savo gynybos barą, paskelbus įsakymą, reikèjo 26 val., todèl Molètu kryptimi priedangos funkcijas iš pradžių turejjo atlikti tik PAB ir šauliai ${ }^{144}$. Vidutiniškai kiekvienas PAB turejo dengti apie $75 \mathrm{~km}$ Lietuvos ir Lenkijos administracinès linijos $(525 \mathrm{~km})$ ruožą.

Dèl pajẻgų ribotų galimybių platesnio masto ofenzyvų - puolimų visu frontu - nebuvo numatyta. Kariuomenès štabas planavo, kad pajėgos, išnaudodamos natūralias gamtines kliūtis (Šventosios, Nevěžio, Neries ir Nemuno upes) trauksis aktyviai gindamosi. Kauno gynyboje buvo numatyta panaudoti tvirtovès fortus. Pradiniame karo etape reikejo siekti būtinai išlaikyti Kauną, kad į Žemaitiją galètų evakuotis centrinès valdžios įstaigos ir telktis kariuomenè, nes laikinoji sostinė buvo svarbiausias mobilizacijos centras. Buvo numatyta, kad karinès pajègos iš Kauno turès atsitraukti priešui iš rytų pasiekus Lapių-Babtų ribą. Kauną ginantys daliniai turejo trauktis už Nevėžio, link Raudondvario. Pasitraukusios iš Kauno Lietuvos kariuomenès pagrindine gynybos riba buvo Nemunas-Nevěžis. Šiaurinį Lietuvos kariuomenès sparną turėjo dengti kavalerijos daliniai, jau minètas 1-asis husarų KP - Molètų bare, 3-iasis dragūnų KP turèjo atvykti ị Raguvos apylinkes, o 2-asis ulonų KP, atlikęs priedangos veiksmus Suvalkijoje, - per Kauną i Vadaktèlių apylinkes (apie $10 \mathrm{~km}$ ị šiaurę nuo Krekenavos). Pagrindiniai ka-

${ }^{144}$ Operacijų planas „L“ 1937 m. kovo 31 d. LCVA, f. 929, ap. 3, b. 995, 1. 3-11. 
riuomenès rezervai (apie $5 \mathrm{PP}$ ) turèjo telktis Pociūnèlių-Vadaktèlių rajone (jie galèjo susitekti susirinkimo rajone maždaug 5-ą dieną po mobilizacijos). Lemiamą reikšmę vykdant mobilizaciją ir telkiant kariuomenę turejjo geležinkeliai ir tiltai, tačiau štabas numatè, kad dèl galimų priešo aviacijos aktyvių veiksmų daliniams gali tekti ilgus nuotolius įveikti pėsčiomis.

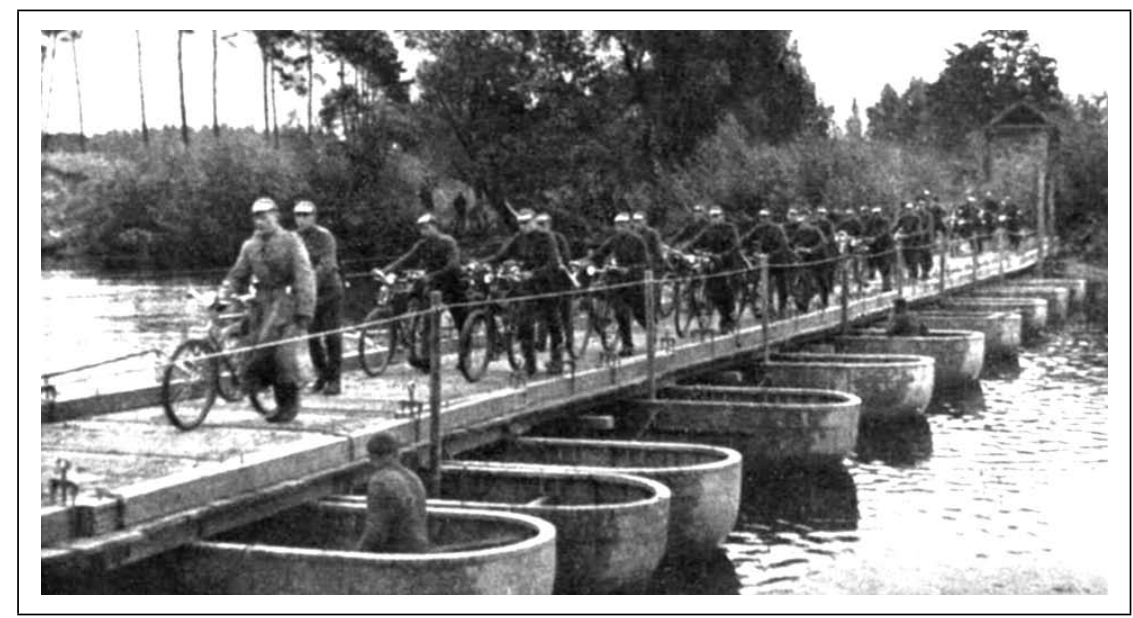

Lietuvos kariuomenè manevrų metu pontoniniu tiltu keliasi per Nevėži. Kardas, 1938 m.

Kariuomenès štabas numatè, kad priešo pajëgu persvarai padidejus ir nepajėgiant išlaikyti Nevėžio gynybinès ribos, kariuomenè turès trauktis, atlikdama priedangos funkcijas, keliomis kryptimis: 1) Kèdainiai-ŠiauliaiKlykoliai (16 km ị šiaurę nuo Akmenès) ir 2) Babtai-Raseiniai-Kelmè-Papilè. Tokiu būdu kariuomenè turèjo susitelkti Lietuvos-Latvijos pasienyje, Mažeikių-Telšių apskričių rajone. Atsitraukimo atveju buvo numatytos 4 tarpinès gynybos linijos:

1. Dubysos-Gynèvès-Šušvės-Daugyvenès upès, laikytos rimtomis kliūtimis;

2. Skirsnemunè-Raseiniai-Šiluva-Šiaulènai-Radviliškis-Vèzgès upė; sunkiai ịveikiamos kliūtys buvo Raseinių miškų masyvas ir Tytuvėnų-Radviliškio baro pelkynai;

3. Kražantès upè-Kiaunoriai-Rèkyvos ežeras-Šiladis upè - šios gynybos linijos centre buvo pelkètų vietovių;

4. Kūros upè-Kuršènai-Tryškiai-Virvyčios ir Ventos upès, laikytos didelèmis kliūtimis. 
Kariuomenès štabo nuomone, patogiausia buvo gintis 2-ojoje ir 3-iojoje gynybos linijoje ${ }^{145}$. Pagal operacijų planą „L“ Priešlėktuvinės apsaugos rinktinè iki evakuacijos turejo susitelkti ir ginti Kauną, vèliau pasirengti Šiaulių, Linkaičių ir Radviliškio gynybai ${ }^{146}$. Evakuotos vyriausybès ir savivaldybių i̊staigos turejjo trauktis ì numatytą rajoną Plungè-Tverai-Varniai-Šiaulènai-Kuršėnai-Akmenè-Mažeikiai-Židikai-Plateliai, prezidentas - apsistoti Telšiuose, KAM ir kariuomenès tarnybų būstinès - įsikurti Šiauliuose, Kariuomenès štabas - Šeduvoje, rezerviniai kariuomenès daliniai - atsitraukti i didesnius Žemaitijos miestus, kad užtikrintų ten tvarką ir prireikus lengviau galètų papildyti savo gretas atsargos kariais ${ }^{147}$. Plane pabrěžiama SSRS laikysenos Lietuvos-Lenkijos konflikto metu reikšmė, numatant, kad ryžtinga SSRS diplomatinè parama ir jègos demonstravimas gali padèti išvengti konflikto. Taip pat numatoma galima SSRS pajègų pagalba Lietuvai kovojant su Lenkija ${ }^{148}$.

Svarbus veiksnys Lietuvos gynybos strategijoje buvo šauliai ir galimybè juos panaudoti partizaniniame kare priešo užimtoje teritorijoje, siekiant taip paremti besikaunančią kariuomenę, demoralizuoti priešą ir išlaikyti nenutrūkstamą pasipriešinimą net kariuomenei ir vyriausybei pasitraukus iš šalies. 1938 m. spalio 3 d. Lietuvos kariuomenès štabo direktyvoje ŠADIR buvo numatyta, kad karo atveju šauliai bus naudojami mobilizacijai ir priedangai organizuoti, esant galimybei - veiks kartu su reguliariosios kariuomenès daliniais. Tačiau dalis būrių privalejjo likti ir kovoti priešo užnugaryje. Direktyvoje rašoma: ,< $<$.. > pirmon eilèn operatyviniams uždaviniams vykdyti laukia savarankiškai veikiant, kaip taisyklè, partizaninio karo pagrindais $<\ldots . .{ }^{*}$ “149.

Priešui netikètai užpuolus Lietuvą, šauliai turejjo pradèti veikti be atskiro įsakymo ${ }^{150}$. Visi būrių vadai buvo žodžiu supažindinti su jų padaliniams

\footnotetext{
${ }^{145}$ Operacijų planas „L “. 1937 m. kovo 31 d. LCVA, f. 929, ap. 3, b. 995, 1. 12-21.

${ }^{146}$ Kariuomenès vado brg. gen. S. Raštikio 1938 m. sausio 21 d. patvirtintas „Kariuomenès būstinès, kariuomenès skaidinio kovos dalių ir evakuotų valstybinių ịstaigų išdèstymo siūlymas“. LCVA, f. 929, ap. 3, b. 1078, 1. 28.

${ }^{147}$ Rezerviniai kariuomenès daliniai turèjo įsikurti: I atsargos pèstininkų batalionas (APB) Mažeikiuose, II APB ir 1-asis atsargos kavalerijos eskadronas (AKE) - Telšiuose, III APB ir 2-asis AKE - Raseiniuose, IV APB - Varniuose, V APB, atsargos artilerijos pulkas ir 3-iasis AKE - Šiauliuose, VI APB - Plungėje, Šarvuočių rinktinè - Radviliškyje, ryšių ir inžinierių batalionai - Šeduvoje: Numatomas kariuomenès būstinès, KAM ịstaigų, evakuotų valstybinių įstaigų išdèstymas apleidus Kauną. Žemèlapis. $L C V A$, f. 929, ap. 3, b. 1078, 1. 30.

148 Operacijų planas „L“. 1937 m. kovo 31 d. LCVA, f. 929, ap. 3, b. 995, 1. 4.

${ }^{149} 1938$ m. spalio 3 d. Šauliams panaudoti direktyva ŠADIR. LCVA, f. 929, ap. 3, b. 1028, 1. 12.

${ }^{150}$ Šauliams panaudoti direktyva ŠADIR. 1938 m. LCVA, f. 561, ap. 12, b. 1021, 1. 22.
} 
keliamais uždaviniais ${ }^{151}$. Prie planų pridètuose žemėlapiuose būriai, kurie turèjo likti užnugaryje ir veikti kaip partizanai, buvo pažymèti atskirai ${ }^{152}$. Šaulių vadams organizuojant mokymus, nurodyta mokyti ,partizaninio būrio veikimo" būdų ${ }^{153}$. Karo atveju šauliai savo gyvenamojoje, gerai pažįstamoje, teritorijoje, veikdami savarankiškai mažais būriais, turèjo taikyti partizaninès kovos taktiką.

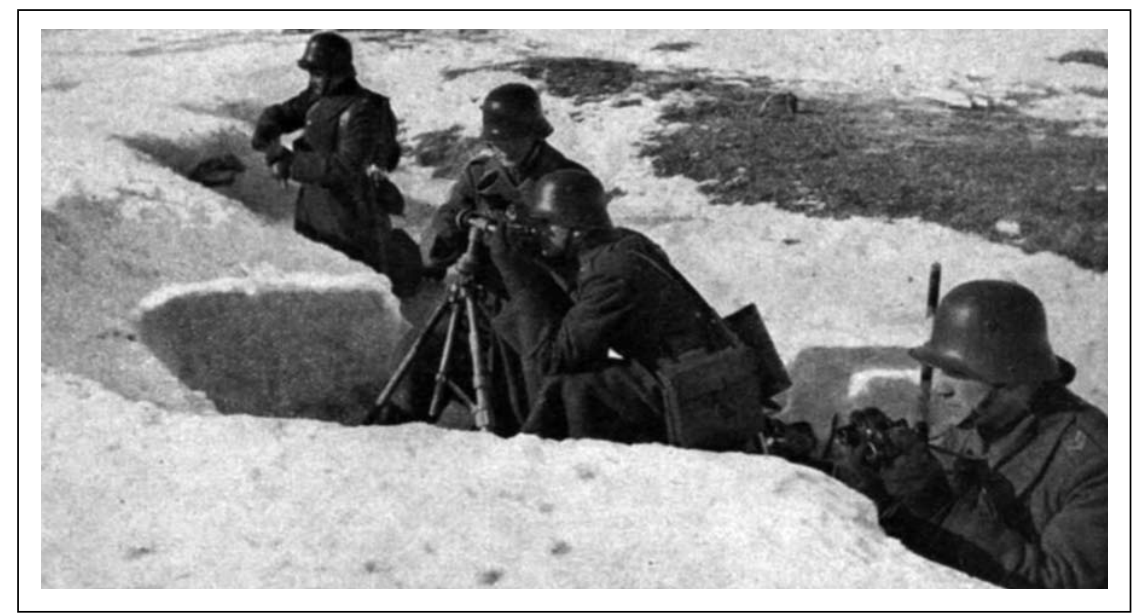

Lietuvos kariai, minosvaidininkų komanda, pozicijose žiemos metu. Kardas, $1940 \mathrm{~m}$.

Vertindamas Lietuvos kariuomenę 1937 m. D. Britanijos karo atašè mjr. C. S. Valè pranešime ị Londoną rašè: , , <..> iki šiol buvo teigiama, kad Lietuvos kariuomenè tarp Baltijos valstybių yra pati silpniausia. Dabar yra atvirkščiai - jos parengimas geriausias.“ İsidemètina ir dar viena britų karo atašè išvada: , < ..> bet kuri šalis, kuri galvoja, kad karo su Lietuva atveju jai teks susidurti su trimis silpnomis ir blogai ginkluotomis divizijomis, didžiai apsirinka." Tokiam vertinimui pritare ir Prancūzijos karo atašė Baltijos valstybėse mjr. Ganevalis, kuris, apibendrindamas padètị 1937 m., teigé, kad Lietuvos kariuomenè buvo ne tik geriausia iš Baltijos valstybių kariuomenių, bet pagal apginklavimo ir pasirengimo lygi turejjo būti priskirta „visai

151 1939-05-27 III pèstininkų divizijos štabo raštas Kariuomenès štabo I skyriaus viršininkui. LCVA, ap. 3, b. 1028, 1. ap. 53.

152 Žemèlapis. LCVA, f. 929, ap. 3, b. 1028, 1. 182-183.

1531938 m. spalio 3 d. Šauliams panaudoti direktyva ŠADIR. LCVA, f. 929, ap. 3, b. 1028, 1. 20. 
kitos kategorijos" kariuomenėms nei Latvijos ar Estijos. Lenkijos ultimatumo išvakarèse $\mathrm{D}$. Britanijos diplomatas Thomas $\mathrm{H}$. Prestonas pranešime $\mathrm{i}$ Londoną rašè, kad agresijos prieš Lietuvą atveju šios „gerai apginkluotos, parengtos ir aprūpintos kariuomenès pasipriešinimas būtų rimtas“. Panašiai Lenkijos ultimatumo dienomis galvojo ir Estijos karo atašè Lietuvoje plk. Vilhelmas Sarsenas, laikęsis nuomonès, kad ,jei vokiečiai nebūtų puolę drauge su lenkais, pastariesiems būtų buvę sunku pasiekti Kauną“, net jei lietuviai ir nebūtų spejję mobilizuoti savo kariuomenès ${ }^{154} .1938$ m. Lenkijos karo atašè plk. Leonas Mitkievičius apie Lietuvos kariuomenę rašè, kad jos pèstininkai primena 1914-1917 m. rusų pèstininkus, savo ginkluote panašūs ị lenkus, ypač dèl to, kad, kaip ir Lenkijos kariai, stokoja prieštankinių pabūklų, tačiau yra drausmingi, puikiai geba greitai ir ištvermingai nužygiuoti didelius atstumus ir gintis mūšio metu, tačiau atakuoja lètokai. Pulkininkui Lietuvos kariuomenè paliko gerą ịspūdị, nors jos motorizacijos lygiu abejojo, bet, anot jo, daug dèmesio buvo skiriama karo aviacijai ir priešlèktuvinei gynybai. L. Mitkievičius konstatavo, kad Lietuvos kariuomenè - tai vienas parengtas korpusas, turintis savo esprit de $\operatorname{corps}^{155}$.

Operacijų plane Nr. 3 „L“ buvo numatyta traukiantis gintis kiek įmanoma išnaudojant gamtines kliūtis. Lietuvos kariuomenei nebuvo keliamas uždavinys ginti sienas bet kokia kaina, nes tai buvo neįmanoma, žinant Lietuvos ir Lenkijos karinių pajègų santykị. Tačiau, manytume, pasirinkta traukimosi manevruojant ir stabdant priešą bei masiškai ardant infrastruktūrą taktika galëjo padèti atsilaikyti keletą savaičių ir atsitraukus ị šiaurinị pasienị internuotis Latvijoje. Svarbų vaidmenị krašto gynyboje turejjo suvaidinti šauliai, kuriems buvo patikėta organizuoti partizaninį karą priešo užnugaryje.

\section{LIETUVOS GYNYBINIAI PLANAI VOKIETIJOS IR LENKI- JOS BENDRO PUOLIMO ATVEJU (PLANAS NR. 2 ,V+L“)}

1938 m. pavasari prasidejus Lietuvos ir Lenkijos politinei krizei, dèl pastarosios pateikto ultimatumo Lietuva buvo ant ginkluoto konflikto dviem frontais slenksčio. Vokietijos karinès jūrų pajėgos buvo sutelktos prie Bornholmo salos, kad galètų Klaipèdą pasiekti per keletą valandų. Eventualiam Lenkijos ir Lietuvos karui Vokietija buvo pasirengusi. A. Hitleris įsakè ge-

\footnotetext{
154 Žalys V. Lietuvos diplomatinès tarnybos ir kariuomenès vadovybės sąveika įtvirtinant Lietuvos valstybingumą 1923-1938 metais // Lietuvos nepriklausomybei - 80. Straipsnių rinkinys. Vilnius, 1999, p. 72-73.
}

${ }^{155}$ Mitkiewicz L. Kauno atsiminimai 1938-1939. Vilnius, 2002, p. 103-113. 
neraliniam štabui parengti Klaipėdos krašto ir aplinkinių Lietuvos rajonų užèmimo planą. 1938 m. kovo 18 d. Vokietijos daliniai Rytprūsiuose įžengé i puolimui parengtas zonas, o desanto korpusas kreiseriais Nürnberg, Köln ir Leipzig pajudejo link Klaipèdos ${ }^{156}$. Pagal planą Flottenparade (liet. Laivyno paradas) puolime turejo dalyvauti apie 15 ịvairių karo laivų. Nors Vokietija 1938 m. kovo mèn. karo su Lietuva nenorejo ir neprovokavo, bet Lenkijai užpuolus Lietuvą ir vokiečiai būtų îsiveržę i jos teritoriją ${ }^{157}$. Vokietijos kariuomene planavo užimti Klaipeddos kraštą ir teritoriją iki Šiaulių, t. y. apie $15000 \mathrm{~km}^{2}{ }^{158}$. Lietuvos vyriausybei Lenkijos ultimatumą prièmus, vokiečiai nutraukè pasirengimą. Taigi šiame kontekste tenka aptarti ir Lietuvos kariuomenès operacijų planą Nr. 2 „V+L“, juo labiau kad jis buvo skirtas ne tik bendram Vokietijos ir Lenkijos puolimui atremti, bet ir tuo atveju, jei regione kiltų plataus masto SSRS, Lenkijos ir Vokietijos konfliktas ir Lietuva būtų i ji ịtraukta. 1938 m. lapkritị SSRS Vyriausioji karinè taryba patvirtino generalinio štabo viršininko B. M. Šapošnikovo strateginị operacijų planą, kuriame buvo numatyta, kad, kilus krizei, lenkai ir vokiečiai kartu okupuos Lietuvą ${ }^{159}$.

$1937 \mathrm{~m}$. sausio $12 \mathrm{~d}$. buvo patvirtintas (1936 m. gruodžio $30 \mathrm{~d}$. parengtas) Lietuvos kariuomenès operacijų planas Nr. 2 „V+L“ (5 priedas). Planu numatyta vadovautis bendros Vokietijos ir Lenkijos agresijos atveju, kai Latvija yra neutrali, o SSRS nusiteikusi palankiai. Plano „A“ variante buvo numatyta, kad Vokietija pirmoji, o vèliau ir Lenkija puls, siekdamos okupuoti ir pasidalyti Lietuvą. Lietuvos kariuomene - analogiškai kaip „V“ ir „L“ planuose, - stabdydama vokiečius, turejo trauktis ir užimti pagrindinę gynybos liniją Venta-Dubysa, o puolantiems lenkams sulaikyti išnaudoti Neries ir Šventosios upes ir užimti pagrindinę gynybos liniją Nemunas-Nevèžis. Pagrindinès kariuomenès pajègos būtų susitelkusios Radviliškio-Pakruojo rajone. Kauno gynyba buvo pavesta II PD ir II PB daliniams, Šventosios upès, o vèliau Nevėžio ribą iš rytų turejjo ginti I PD, palei Dubysą

\footnotetext{
${ }^{156}$ Vareikis V. Klaipéda XX amžiuje. Klaipèda, 1993, p. 42.

${ }^{157}$ Liekis Š. „Laivyno paradas“ ir neịvykusi Klaipedos okupacija 1938 m. Nežinomi Lietuvos ir Vokietijos santykių puslapiai // Genocidas ir rezistencija. Red. D. Kuodytè. 2004, Nr. 2 (16), p. 163-168.

${ }^{158}$ Rauch G. The Baltic States: The years of independence Estonia, Latvia, Lithuania 1917-1940. London, 2006, p. 196.

${ }^{159}$ Numatyta, kad SSRS gali tekti kariauti dviem frontais: rytuose ją galèjo pulti Japonija, o vakaruose - Vokietija, Italija, Lenkija, galbūt Rumunija ir Pabaltijo valstybès, kurios bendrai sutelktų apie 229 divizijas: Гланц Д. Колосс поверженный. Красная Армия в 1941 г. Москва, 2008, с. 130-131.
} 
(nuo jos ir Nemuno santakos iki Lyduvėnų) - IV PD, o šiauriau - III PD ir I PB. Planuota, kad priešai, vengdami tarpusavio nesusipratimų, puls atskiromis kryptimis, kad neturètų sąlyčio. Pagal planą galimos Vokietijos puolimo kryptys: 1) Kybartai-Kaunas; 2) Smalininkai-Raseiniai; 3) Tilžè-Tauragè-Šiauliai, o Lenkijos: 1) i pietus nuo Neries link Kauno, palei geležinkelị Vilnius-Kaunas; 2) Maišiagala-Kèdainiai; 3) nuo Švenčionių ir Pabradès link Panevėžio. Pabrěžta, kad pavojingiausia - trečioji vokiečiu puolimo kryptis, kur ejjo svarbios komunikacijos (geležinkelis ir plentas) ir nebuvo sunkiai ịveikiamų gamtinių kliūčių. Nepavojingiausia dèl prasto kelių tinklo ir gynybai palankaus reljefo laikyta trečioji Lenkijos puolimo kryptis ị Panevèžį ${ }^{160}$.

Plano „B“ variantas buvo parengtas tam atvejui, jei kiltų Lenkijos ir Vokietijos karas su SSRS, o Lietuva taptų jo veiksmų arena. Buvęs carinės Rusijos gen. Nikolajus N. Golovinas, vertindamas SSRS karines pajëgas vakaruose, teigè, kad, kilus Sovietų Rusijos ir Lenkijos karui, Lietuva neliks neutrali ir 4 lietuvių PD atitrauks ne mažiau kaip 2 lenkų $\mathrm{PD}^{161}$. Konstatuota, kad Latvijai tokiu atveju likti nuošalyje taip pat nepavyks, nes didžiosios kaimynès nepaisys jos neutralumo. Plane teigiama, kad Lietuvos ir Latvijos tikslas vienas - išsaugoti nepriklausomybę, todèl šalys turètų derinti savo politiką ir stoti vienos iš kariaujančių valstybių pusėn. Numatyta, kad, kilus konfliktui tarp didžiųjų šalių, Lietuvos kariuomenès mobilizacija turètų prasidèti iš anksto, nelaukiant invazijos. Taip pat konstatuota, kad tokiu atveju labiau tikètina Vokietijos kariuomenès invazija. Gintis planuota, kaip numatyta operacijų plane $\mathrm{Nr} .1$ „, $\mathrm{V}^{“ 162}$, pasienyje su Lenkija palikti priedangos rinktines ir priešui leisti užimti Suvalkiją. Plane siūloma naujas įmones ir sandèlius statyti saugiausiose teritorijose - Biržų-Pušaloto-Šiaulių-Joniškio rajone ${ }^{163}$. Vyriausybė ir valstybès įstaigos, kilus konfliktui, turëjo būti evakuotos ị Šiaurès Lietuvą, ị Žemelio-Linkuvos-Meškuičių-GruzdžiųŽagarès rajoną Latvijos pasienyje, Respublikos Prezidentas - icsikurti Joniškyje, KAM - Šiauliuose, o Lietuvos kariuomenès štabas - Šeduvoje ${ }^{164}$.

Operacijų plane daroma išvada: „Esame maža, silpnai ginkluota vals-

${ }^{160}$ Operacijų planas Nr. 2 „V+L“. 1937 m. sausio 12 d. LCVA, f. 929, ap. 3, b. 994, 1. 3-9, 30.

${ }^{161}$ Головин Н. Н. Мысли об устройстве будущей Российской вооруженной силы. 4-е издание. Белград, 1939, с. 68.

162 Plačiau aptariama: Jokubauskas V. Tuščias šūvis: galimybès atremti Vokietijos karinę grèsmę 1939 metais // Istorija. T. 73. Ats. red. S. Grigaravičiūtė. Vilnius, 2009, p. 25-36.

163 Operacijų planas Nr. 2 „V+L“. 1937 m. sausio 12 d. LCVA, f. 929, ap. 3, b. 994, 1. 21-23.

${ }^{164}$ Numatomas kariuomenès būstinès, KAM įstaigų, evakuotų valstybinių įstaigų išdèstymas apleidus Kauną. Žemėlapis. LCVA, f. 929, ap. 3, b. 1078, 1. 30. 
tybė. Ginkluota jẻga atsilaikyti prieš bendrą vokiečių ir lenkų puolimą negalèsime. Toks karas reikštų mums tikrą ir neišvengiamą katastrofą. Mūsų diplomatija privalo su lenkais arba su vokiečiais igyvendinti gerus santykius ir laiduoti mūsų rytų arba vakarų sienų saugumą. ${ }^{165}$

XX a. ketvirtojo dešimtmečio pabaigoje Vokietijai užpuolus Lietuvą, Latvija taip pat planavo įsitraukti ị karą Lietuvos pusėje. Tačiau tokius planus derètų vertinti ne kaip sajunginę paramą, o kaip prevencinius veiksmus, žinant, kad ir Latvija bus užpulta. Latvijos gynybinis planas „D“ (Dienvidi, liet. „Pietūs“), parengtas 1938 m. po Austrijos anšliuso, buvo suderintas su Lietuvos kariuomenès štabu ${ }^{166} .1938$ m. liepos 2 d. Latvijos kariuomenès vadas gen. Krišjanis Berkis išleido direktyvą Nr. 102, kurioje buvo patvirtintas operacijų planas „D“. Latvijos kariuomenès štabas manė, kad Vokietijos armija, įsiveržusi ị Lietuvą, pasienị su Kuršu pasieks per 3, o kitose vietose - per 7 dienas. Latvijos karinè vadovybė planavo, mobilizavusi savo kariuomenę, 4 PD išdèstyti Lietuvos teritorijoje, palei liniją Bartuvos upèSkuodas-Seda-Kuršènai-Šiauliai-Panevěžys. Rytų pasienį turèjo dengti viena III Latgalos PD, o IV Žiemgalos PD likti rezerve Pietų Latgaloje ${ }^{167}$. Žinoma, Latvijos karinis planas „D“ buvo gynybinis, skirtas eventualiai Vokietijos grèsmei atremti, ir lietuviai, kilus ginkluotam konfliktui su Lenkija, karinès paramos tikètis negalejo.

Lietuvos kariuomenès operacijų planas Nr. 2 „V+L“ akivaizdžiai liudija, jog štabas kritiškai vertino savo pajëgas konflikto dviem frontais atveju. Aiškejja, kad SSRS operacijų planuose laikoma strategine partnere ${ }^{168}$,

${ }^{165}$ Operacijų planas Nr. 2 „V+L“. 1937 m. sausio 12 d. LCVA, f. 929, ap. 3, b. 994, 1. 23.

${ }^{166}$ Pētersons A. Krustugnis. 60 gadus no tautas slēptais 1940-1945. Rīga, 2007, 1. 86.

${ }^{167}$ Latvijos kariuomenę po mobilizacijos turèjo sudaryti 7 PD, 1 rezervinė PD, 143418 karių (iš maždaug 110000 kovinių dalinių): Kuzmins V. Latvijas bruṇoto spēku mobilizācijas un aizsardzības plāni 1939. gada beigās-1940. gada sākumā // Militārais apskaits. Red. K. Krēsliṇš. 2009, Nr. 3/4, 1. 49-56.

${ }^{168}$ Operacijų plane „L“ teigiama: „Jei SSSR vyriausybė duotų lenkams aiškiai suprasti, kad prie Lietuvos užgrobimo neprileis ir tuo pat metu imtų demonstruoti savo jëgomis rytiniam Vilniaus koridoriaus pasieny. $<\ldots>$ Naudinga būtų, kad lenkams pradejus pulti Lietuvą, SSSR kariuomenè ateitų mums pagalbon, puldama lenkų jègas iš užnugario.“: Operacijų planas „L“. 1937 m. kovo 31 d. LCVA, f. 929, ap. 3, b. 995, 1. 4; Konflikto su Vokietija atveju operacijų plane „V“ numatyta į SSRS bandyti prasiveržti per Vilniaus kraštą. Lietuvos kariuomenè ir vyriausybẻ turèjo trauktis šiaurès rytų kryptimi, link Zarasų, nes tai buvo tolimiausias taškas nuo sienos su Vokietija. Bandant prasiveržti per „Vilniaus koridorių“ ị SSRS, Lietuvos kariuomenès pietinị sparną nuo lenkų planuota dengti Indrulių-Dysnų ež. ir Dysnos upès ruože. Nuo Smalvos (šalia administracinès linijos) iki SSRS judant tiesia linija buvo maždaug $65 \mathrm{~km}$, o apie $138 \mathrm{~km}$ kelias èjo linija Zarasai-Turmantas-Breslauja-Mejory-Drysa. Tačiau šiaurinis Lenkijos-SSRS sienos ruožas sutapo su Dauguvos upe, todėl kariuomenei būtų reikèję statyti pontoninius tiltus, nes stacionarių šiame 
nesunku nuspėti, kokios valstybės pusėn, kilus konfliktui, buvo rengiamasi stoti. Tačiau kartu sakoma, kad diplomatai turi palaikyti draugiškus santykius bent su viena iš didžiujų kaimyninių šalių (Lenkija arba Vokietija). Kita vertus, manytume, kad XX a. ketvirtojo dešimtmečio pabaigoje pagrindiniu eventualiu priešu Lietuvos kariuomenè laikẻ Vokietiją. Galima teigti, kad 1939 m. rugsejjo mèn. Lietuvos kariuomenès stiprinimas ir daliné mobilizacija vyko atsižvelgiant $i \mathrm{i}, \mathrm{V}+\mathrm{L}$ “ plane nubrèžtas karinio saugumo užtikrinimo gaires regioninio karinio konflikto atveju. Kariuomene buvo pradèta telkti ir mobilizuoti atsižvelgiant ị karo veiksmų pobūdị ir eigą kaimyninèse valstybèse ir iš dalies demobilizuota pasibaigus aktyviems karo veiksmams arti Lietuvos sienų.

\section{LIETUVOS IR LENKIJOS KARINIŲ PAJĖGŲ SANTYKIS XX A. KETVIRTOJO DEŠIMTMEČIO PABAIGOJE}

Tarpukario Lenkijos teritorijoje (389 685 km²) 1939 m. gyveno 35339000 gyventojų ${ }^{169}, 1935 \mathrm{~m}$. (taikos metu) jos kariuomenę sudaré apie 350000 karių ${ }^{170}$, šalis buvo padalyta ị 10 karo apygardų, kiekvienoje iš jų buvo dislokuota po korpusą. ${ }^{171}$ Karo atveju Lenkijos kariuomenę turejo sudaryti 40 PD, $1 \mathrm{~PB}, 11 \mathrm{~KB}$, Motorizuotoji brigada, 50 pèstininkų batalionų, 30 atskirụjų artilerijos divizionų ir kt. ${ }^{172}$ Pagal planą „W2“ Lenkija 1939 m. rengèsi sutelkti 1350000 kariu armiją ${ }^{173} .1936 \mathrm{~m}$. Lenkijoje buvo 6951528 vyrai, pagal amžių (21-50 m.) tinkami karo tarnybai ${ }^{174}$.

1939 m. Lenkijos kariuomenè turejjo apie 1229400 šautuvų ir karabinų, 42915 lengvųų ir sunkiụjų kulkosvaidžių, 510 priešlèktuvinių pabūklų, apie $2130(81 \mathrm{~mm})$ minosvaidžių, $1265(37 \mathrm{~mm}) w z .36$ prieštankinius pabūklus,

ruože nebuvo: Operacijų planas Nr. 1 „V“. 1937 m., vasario 8 d. $L C V A$, f. 929, ap. 3, b. 993, 1. 9; Paskutinè (septinta) Lietuvos kariuomenès gynybos riba pagal planą „V“ žemėlapyje buvo pažymèta ežerų Cičirys-Avilys-Luodis-Dysnai ir Dysnos upès ruože, jau už administracinès linijos: Žemėlapis „V“, eilinès stabdymo ribos. Priedas Nr. 6. LCVA, f. 929, ap. 3, b. 993, 1. 24.

${ }^{169}$ Vaičenonis J. Lietuvos kariuomenès modernizacija (1926-1939) // Darbai ir dienos. T. 21. Red. L. Gudaitis. Kaunas, 2000, p. 147.

${ }^{170}$ Davies N. Dievo žaislas Lenkijos istorija, Vilnius, 2002, t. 2, p. 460.

${ }^{171}$ Dzieje Polski. Atlas ilustrowany. Red. W. Sienkiewicz, E. Olczak. Warsawa, 2008, s. 348.

172 Jurga T. Oborona Polski 1939. Warszawa, 1990, s. 44-45.

${ }^{173}$ Komornicki S. ir kt. Wojsko Polskie 1939-1945. Warszawa, 1984, s. 8.

${ }^{174}$ Buvo 390580 vyrų (1913-1914 m. gimimo), 1979301 - iki 35 m. (1901-1912 m. gim.), 821602 - nuo 36 iki $40 \mathrm{~m}$. (1896-1900 m. gim.), iš viso - 3191483 vyrai ir 1096076 vyrai nuo 41 iki 50 m. (1886-1895 m. gim.): Jurga T. Oborona Polski 1939. Warszawa, 1990, s. 43. 
3429 patrankas, haubicas ir mortyras ${ }^{175}$, taigi iš viso 7334 įvairius artilerijos pabūklus. 1939 m. rugsẻjo 1 d. jos karines oro pajëgas sudaré 712 lèktuvų, iš jų 392 koviniai ir 12 hidroplanų ${ }^{176}$. Kariuomenè turejjo 1617 TP ir Vickers Amstrong $6 t$, 102 senus Renault FT-17 ir 50 Renault R-35 lengvųų tankų, $574 T K, T K S, T K F$ tanketes, 100 šarvuočių ir 10 šarvuotų traukinių ${ }^{177}$. Taigi iš viso 887 ịvairius tankus ir tanketes. Lenkija disponavo 19 jūrų karo laivų, kurių bendras tonažas siekè 18388 t. Visi minèti laivai kartu turèjo 46

1751939 m. rugsèjo 1 d. Lenkijos kariuomenè turèjo minosvaidžių: apie $900-81 \mathrm{~mm} \mathrm{wz.} \mathrm{31,}$ $590-81 \mathrm{~mm} \mathrm{wz.} 28$ ir $640-81 \mathrm{~mm} \mathrm{wz.} 18$; priešlèktuvinių pabūklų: 350 - $40 \mathrm{~mm} \mathrm{wz.} \mathrm{36,} 52$ - 75

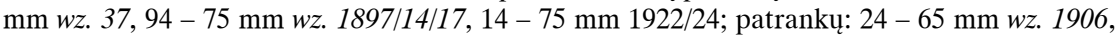
1374 - $75 \mathrm{~mm} \mathrm{wz.} \mathrm{1897,} 466$ - $75 \mathrm{~mm} \mathrm{wz.} \mathrm{1902/26,} 254-105 \mathrm{~mm} w z .13$ ir wz. 29, 43 - 120 mm 1878/09/31; haubicų: apie $900-100 \mathrm{~mm} w z .14 / 19,341$ - $155 \mathrm{~mm} \mathrm{wz.} \mathrm{17;} \mathrm{mortyrų:} 27$ $220 \mathrm{~mm} w z$. 32: Ilość uzbrojenia Wojska Polskiego w sierpniu 1939 r. [interaktyvus]. [žiūrèta 201008 14]. Interneto prieiga <http://www.wojsko18-39.internetdsl.pl/wrzesien/iloscuzbrojenia. html>; 1934 m. balandžio 1 d. Lenkija turejjo 1603906 šautuvus ir karabinus: Jagiełło Z. Piechota wojska Polskiego 1918-1939. Warszawa, 2005, s. 193; Kiti autoriai nurodo Lenkiją turejjus apie 9500 ịvairių artilerijos pabūklu (4 500 patrankų ir minosvaidžių, 2000 prieštankinių ir 3000 priešlèktuvinių pabūklų): Молло Э. Вооруженные силы Второй мировой. Структура, униформа, знаки различия, Москва, 2005, с. 20; Arba 2065 sunkiuosius artilerijos ir 774 prieštankinius pabūklus, 475 tankus, 388 karo lèktuvus: Hempel A. Poland in World War. II An Illustrated Military History. New York, 2005, p. 7; Patrankų: 1840 - 75 mm, 254 - 105 mm, 43 - 120 mm, 24 - 65 mm; haubicų: 900 - $100 \mathrm{~mm}, 341$ - $155 \mathrm{~mm}$; $27220 \mathrm{~mm}$ mortyras, iš viso 3 429: Wyszczelski L. W obliczu wojny. Wojsko Polskie 1935-1939. Warszawa, 2008, s. 279. ${ }^{176}$ Cynk J. B. Siły lotnicze Polski i Niemiec. Wrzesień 1939. Warszawa 1989, s. 96. Kiti autoriai teigia, kad Lenkija turèjo 824 lèktuvus, iš jų 407 kovos: Кирьян М. М. ir kt. История военного искусства. Москва, 1986, с. 148. 745 skirtingų modelių lẻktuvus: Komornicki S. ir kt. Wojsko Polskie 1939-1945. Warszawa, 1984, s. 16; 482 karo lèktuvai buvo rikiuoteje ir 290 rezerve, iš viso 772: Pawłowski T. Armia marszałka Śmigłego. Idea rozbudowy Wojska Polskiego 1935-1939. Warszawa, 2009, s. 150.

177 Jurga T. Oborona Polski 1939. Warszawa, 1990, s. 57; Minètus duomenis nurodo ir Rajmundas Szubańskis, teigdamas, kad 1939 m. rudenị koviniuose Lenkijos armijos daliniuose buvo 887 tankai ir tanketes: $161-7-T P$ ir Vickers-Amstrong $6 t$., 50 - Renault R-35, 102 - Renault FT-17, 274 - TKS, 300 - TK-3, taip pat 100 šarvuočių: Szubański R. Polska broń pancerna 1939. Warszawa, 1982, s. 58; Kitais duomenimis, kariuomenè turejjo 340 tankų: 170 - lengvuju 7 TP, 50 - Vickers E, 67 - Renault FT-17, 53 - Renault R-35, apie 700 - TK ir TKS tankečiu, 100 šarvuočių: Молло Э. Вооруженные силы Второй мировой. Структура, униформа, знаки различия, Москва, 2005, с. 21; Arba: 132 - 7TP, 38 - Vickers-Amstrong E 6 t., 102 - Renault FT-17, 53 - Renault R-35, 3 - Hotchkiss H 35 tankus, 300 - TK-3 ir 274 TKS tanketes, 15 šarvuočių: Ilość uzbrojenia Wojska Polskiego w sierpniu 1939 r. [interaktyvus]. [žiūrèta 201008 14]. Interneto prieiga: <http://www.wojsko18-39.internetdsl.pl/wrzesien/iloscuzbrojenia.html>; Ginkluoteje buvo tankų: 123 (132) - 7 TP, 22 - Vickers-Amstrong 6 t. A, 16 - Vickers-Amstrong 6 t. B, 102 - Renault FT-17, 50 (53) - Renault R-35, 3 - Hotchkiss H 35, 1 - A11 Matilda, 561 (569) - TK-3 ir TKS tankete, šarvuočių: $70-w z .34,11$ (10) - wz. 29: Solarz J. Tank Power Polska 1939. Militaria, Nr. 277, s. 56, 72; 220 lengvụjų tankų ir 650 tankečių: Кирьян М. М. ir kt. История военного искусства. Москва, 1986, с. 148. 
artilerijos $(75-130 \mathrm{~mm})$ pabūklus, 66 torpedų aparatus ir 61 priešlèktuvini (13 mm ir $40 \mathrm{~mm}$ ) pabūklą ${ }^{178}$. Karo atveju galejo mobilizuoti 24 žvejų katerius ir 14 pagalbinių laivų. $1939 \mathrm{~m}$. Lenkijos upių laivynas taip pat buvo gana gausus: 6 monitoriai, 3 kanonierių, 7 kovos laivai, 21 kovinis kateris, 1 minininkas, 7 upių traleriai ir 30 îvairios paskirties laivų. Tačiau, nepaisant dydžio, Lenkijos kariuomene buvo silpna ${ }^{179}$. XX a. karybos teoretikas britas Basilis Henris Lidelis Hartas teigè, kad tarpukario Lenkijos karybos metodai dèl tikejjimo brangiai kainuojančios kavalerijos atakų veiksmingumu, techninio atsilikimo nuo kitų didžiųjų Europos valstybių, tankų, prieštankinių ir priešlèktuvinių pabūklų stokos buvo pasenę. Be to, lenkų armija gerokai buvo pervertinama. Lenkija, anot B. H. Lidelio Harto, per mažai dėmesio ir lèšų skyrẻ karo aviacijai, šalis kūrè gausias sausumos pajẻgas tinkamai neįvertindama, kad jų veiklos efektyvumui užtikrinti būtina priedanga iš oro $^{180}$. Be to, Lenkija, planuodama karo veiksmus, taike kontratakos koncepciją, buvo ịsitikinusi, kad jos menkai motorizuota kariuomenè pajègi kontratakuoti ir taip gintis, ir neišnaudojo gynybos traukiantis ir manevruojant galimybių ${ }^{181}$.

Bandant lyginti šalių karines pajègas labai sunku pasirinkti tinkamus kriterijus, objektyviai ịvertinti to paties tipo, bet skirtingų modelių ginkluotę. Taip pat svarbus aspektas - kintantys statistiniai duomenys, nes kiekviena kariuomenė nuolatos įsigyja vis naujų ginklų, didina amunicijos atsargas,

\footnotetext{
1784 eskadriniai minininkai, 5 povandeniniai laivai, 1 minininkas, 6 traleriai, 2 kanonierès, 1 torpedinis laivas (naikintojas): Burza ir Wicher 1930-1932 m. (1 540 t, 107,2 x 10,5 x 3 m, ginkluote: 4 patrankos - $130 \mathrm{~mm}, 2$ - $40 \mathrm{~mm}, 4$ kulkosvaidžiai - $13 \mathrm{~mm}, 6$ torpedų aparatai $550 \mathrm{~mm}, 60 \mathrm{minu})$, Grom ir Btyskawica $1937 \mathrm{~m}$. (2144 t, 114 × 11,3 x 3,1 m, turejjo 7 patrankas $120 \mathrm{~mm}, 4-40 \mathrm{~mm}, 8$ kulkosvaidžius $-13 \mathrm{~mm}, 6$ torpedų aparatus $-550 \mathrm{~mm}, 60 \mathrm{minu})$, Wilk, Ryś ir Żbik 1931-1932 m. (980/1250 t, 78,5 x 5,9 x 4,2 m, turejo 1 patranką - 100 mm, 2 kulkosvaidžius - $13 \mathrm{~mm}, 6$ torpedų aparatus $-550 \mathrm{~mm}, 38$ minas), Orzet ir Sęp $1939 \mathrm{~m}$. (1100/1473 t, $84 \times 6,7 \times 4,2 \mathrm{~m}$, turejo 1 patranką $-105 \mathrm{~mm}, 2-40 \mathrm{~mm}, 12$ torpedų aparatų $-550 \mathrm{~mm})$, Gryf 1938 m. (2250 t, 103,2 x 13,2 x 3,6 m, ginkluotè: 6 patrankos -120 mm, $4-40$ mm, 4 kulkosvaidžiai - 13 mm, 300 minų), Jaskolka, Mewa, Rybitwa ir Czajka 1935-1936 m. (165 t, 45 x 5,5 x 1,6 m, ginkluotè: 1 patranka - 75 mm, 20 minu), Czapla ir Žuraw 1939 m. (185 t, 45 x 5,5 x 1,7 m, ginkluotè: 1 patranka - 75 mm , 2 kulkosvaidžiai - $13 \mathrm{~mm}, 20 \mathrm{minu})$, Komendant Pitsudski ir Generat Haller 1921 m. (342 t, 50 x 7,2 x 2,9 m, ginkluotè: 2 patrankos - 75 mm, 2 kulkosvaidžiai - $13 \mathrm{~mm})$, Mazur $1915 \mathrm{~m}$. perstatytas $1921 \mathrm{~m}$. ir $1937 \mathrm{~m}$. (360 t, 62,6 x 6,2 x 2,3 m, ginkluotè: 3 patrankos -75 mm, 1-40 mm, 2 kulkosvaidžiai - $13 \mathrm{~mm}$ ): Lipiński J. Druga wojna światowa na morzu. Gdańsk, 1976, s. 29, 733-734.

${ }^{179}$ Vaičenonis J. Lietuvos kariuomenès modernizacija (1926-1939) // Darbai ir dienos. T. 21. Red. L. Gudaitis. Kaunas, 2000, p. 148-149.
}

180 Лиддел Гарт Б. Вторая мировая война. Москва, 1999, с. 39-41.

${ }^{181}$ Ten pat, c. $50-51$. 
formuoja naujus dalinius. Kita problema vertinant pajègas - tai skirtingas šalių ir turimų materialinių išteklių dydis. Be to, sunkumų kelia ir statistinių duomenų kaita, nes bet kuri kariuomenè nuolat įsigyja naujos ginkluotès, o dalį senos nurašo arba parduoda, taigi skaičiai kinta, ir tai turi įtakos komparatyviniam santykiui. Tačiau, vienodai vertinant, akivaizdu, kad Lietuva ir Lenkija - kaip nykštukẻ ir milžinè. Lenkijos teritorija - apie 7 kartus didesnè nei Lietuvos, o gyventojų - daugiau 13,7 karto. Taikos metu Lenkijos kariuomenè taip pat buvo apie 15 kartų didesnè (1939 m. po mobilizacijos ji turejo sudaryti apie $4 \%$, o Lietuvos - apie $5 \%$ gyventojų), joje turejjo tarnauti apie 10-11 kartų daugiau karių nei mobilizuotoje Lietuvos kariuomenejje. Artilerijos pabūklų, minosvaidžių, prieštankinių ir priešlėktuvinių ginklų ši valstybe turèjo 13,4, karo lèktuvų - 6,2 karto, tankų ir tankečių 20 kartų daugiau, o apie karo laivyną net neverta kalbèti - ką reiškẻ 1 Lietuvos mokomasis karo laivas prieš 19 Lenkijos karo laivų.

Tačiau jei tuos pačius rodiklius palyginsime atsižvelgdami i gyventojų skaičių, vaizdas iš esmès pasikeis. Toks vertinimo ir lyginimo metodas, manytume, yra objektyvesnis, nes Lietuva, būdama daug kartų mažesnè, negalejo turèti tokio pat dydžio kariuomenès kaip Lenkija ir ịsigyti ar pasigaminti tiek pat ginklų. 1939 m. 10000 gyventojų Lietuva ${ }^{182}$ vidutiniškai turèjo: 0,17 tanko, 0,45 lèktuvo, 2,13 artilerijos pabūklo ${ }^{183}, 510$ šautuvų, 17,48 kulkosvaidžio, o Lenkija - 0,25 tanko (tanketès), 0,2 lèktuvo, 2,07 artilerijos pabūklo, 348 šautuvus, 12,14 kulkosvaidžio. Taikos metu tiek Lietuvos, tiek Lenkijos kariuomenę sudarè apie $1 \%$ gyventojų. Lietuva atsiliko tik turimų tankų, bet lenke lèktuvų, šautuvų, kulkosvaidžių ir artilerijos pabūklų skaičiumi, nors iš esmès valstybei, kuri planavo gynybinị ir partizaninị karą, aviacija ir juo labiau tankai nebuvo strategiškai svarbūs.

$1935 \mathrm{~m}$. pradètas igyvendinti Lenkijos kariuomenès modernizavimo planas. Tam kasmet reikejjo apie 790-800 mln. zlotų $^{184}$. Nors Lenkijos biudžeto pajamos nuo 3029 mln. zlotų 1929-1930 m. sumažèjo iki $1958 \mathrm{mln}$.

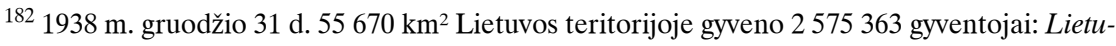
vos statistikos metraštis. 1938 m. Kaunas, 1939, p. 16.

${ }^{183}$ Skaičiuodami statistinius vidurkius ėmėme visų sistemų ir tipų Lietuvos ir Lenkijos artilerijos pabūklus: patrankas, haubicas, prieštankinius, priešlèktuvinius pabūklus ir minosvaidžius. ${ }^{184}$ Vaičenonis J. Lietuvos kariuomenės modernizacija (1926-1939) // Darbai ir dienos. T. 21. Red. L. Gudaitis. Kaunas, 2000, p. 147-148.
} 
zlotų 1935-1936 m. ${ }^{185}$, 1935-1936 m. kariuomenei buvo skirta $768 \mathrm{mln} .{ }^{186}$, 1936-1937 m. - 768 mln., 1937-1938 m. - 777,5 mln., 1938-1939 m. $831,4 \mathrm{mln}$. zlotų, o $1939-1940 \mathrm{~m}$. buvo numatyta išleisti $800,2 \mathrm{mln}$. zlotų ${ }^{187}$. 1938-1939 m. Lenkijos biudžetas siekè $2475 \mathrm{mln}$. zlotų, taigi kariuomenei buvo skirta apie 33,59 \% visų valstybės pajamų ${ }^{188} .1933-1939 \mathrm{~m}$. Lenkija kariuomenès reikmėms atseikejjo apie $5900 \mathrm{mln}$. zlotų (apie $1242 \mathrm{mln}$. JAV dolerių). Be to, $1936 \mathrm{~m}$. Lenkijai Prancūzija suteikè $2250 \mathrm{mln}$. frankų paskolą (apie $600 \mathrm{mln}$. zlotų), 1936-1939 m. iš $4186 \mathrm{mln}$. zlotų, skirtų Lenkijos valstybès gynybai, apie $350 \mathrm{mln}$. zlotų sudaré Prancūzijos paskola ${ }^{189}$. Anot kito autoriaus, 1936-1939 m. Lenkijos nacionalinès pajamos siekè 48 mlrd. zlotų, iš kurių 4003 mln. zlotų $(8,4 \%)$ buvo skirti gynybai finansuoti. Apskritai $1938 \mathrm{~m}$. Lenkijos nacionalinès pajamos 1 gyv. buvo 96 JAV doleriai ${ }^{190}$, arba apie $566 \mathrm{Lt}$, o Lietuvos - apie $500 \mathrm{Lt}^{191}$. $1938 \mathrm{~m}$. iš Lietuvos biudžeto $\left(366,4875 \mathrm{mln}\right.$. Lt) $85,1935 \mathrm{mln}$. Lt $(23,24 \%)$ buvo skirta KAM ${ }^{192}$. Lietuvoje iš krašto apsaugai skirtų lëšų 1 gyventojui vidutiniškai teko apie 33 Lt, Lenkijoje - apie 25,5 Lt, ankstesniais metais Lenkijos šis rodiklis buvo

185 Pawłowski T. Armia marszatka Śmigłego. Idea rozbudowy Wojska Polskiego 1935-1939. Warszawa, 2009, s. 54.

${ }^{186}$ Iš minètų sumų 1935 m. 45,1 mln. zlotų buvo skirti karo laivynui (iš jų 17,2 mln. zlotų naujų laivų statybai): Svetimosios kariuomenès: Lenkija//Kardas. 1936, Nr. 7 (236), p. 197. Dar prieš igyvendinant modernizavimo planą $1933 \mathrm{~m}$. Lenkija kariuomenei skyrė 845,1 mln. zlotų (34,38 \% biudžeto lèšų). 1934 m. sausio duomenimis, Lenkijos kariuomenejje buvo 299818 karių (iš jų 33803 pasienio apsaugos pajègose): Mūsų ir kaimynų kariuomenès $1934 \mathrm{~m}$. sausio mèn. // Kardas. 1934, Nr. 4, p. 79.

${ }^{187}$ Pawłowski T. Armia marszałka Śmigłego. Idea rozbudowy Wojska Polskiego 1935-1939. Warszawa, 2009, s. 66. Anot kito autoriaus, 1936-1937 m. Lenkijos biudžetas buvo $2212 \mathrm{mln}$. zlotų, iš jų kariuomenei skirta 766 mln., 1937-1938 m. biudžetas - 2335 mln., kariuomenei 770 mln. zlotų, 1938-1939 m. biudžetas - 2475 mln. zlotų, o kariuomenei skirta 800 mln. zlotų: Wyszczelski, L. W obliczu wojny. Wojsko Polskie 1935-1939. Warszawa, 2008, s. 190.

1881 JAV doleris 1937 m. kainavo 5,28 zloto: Wydatki i dochody budżetowe niektórych państw [interaktyvus]. [Žiūrèta 201007 31] Interneto prieiga: <http://www.wojsko18-39.internetdsl. $\mathrm{pl} /$ wrzesien/statystyka.html>.

${ }^{189}$ Moczulski L. Wojna Polska 1939. Warszawa, 2009, s. 454.

${ }^{190}$ Czubk̆ński A. Historia drugiej wojny Światowej 1939-1945. 2008, s. 22-23.

${ }^{191}$ Vaskela G. Lietuva 1939-1940 metais. Kursas $i$ valstybès reguliuojama ekonomika. Vilnius, 2002, p. 20.

192 Lietuvos statistikos metraštis. 1939 m. Vilnius, 1940, p. 333-335. 
aukštesnis $^{193}$. 1933-1939 m. Lietuvos biudžeto pajamos siekè 2 105,336 mln. Lt (apie 355,6 mln. JAV dolerių) ${ }^{194}$, iš jų 495,737 mln. Lt (83,74 mln. JAV dolerių) buvo atiduota KAM, t. y. apie 23,55 \%, o 1936-1939 m. -329,3 mln. Lt (55,6 mln. JAV dolerių), apie 24,78 \% biudžeto ${ }^{195}$. Taigi $1933-1939 \mathrm{~m}$. Lenkija gynybos reikalams lèšų skyrè apie 14,8 karto daugiau nei Lietuva, o tai iš esmès beveik atitiko šalių dydžio (gyventojų skaičiaus) santykį.

Tarpukario Lietuvos karinè galia, t. y. valstybès materialiųjų išteklių ir dvasinių jègų visuma bei gebejjimas jas mobilizuoti siekiant karo tikslų ir sprendžiant saugumo problemas, regiono ir grèsmių kontekste buvo gana ribota. Taip pat ir dẻl kuklių valstybès ekonominių, socialinių, politinių bei techninių galimybių. O iki XX a. vidurio jos karinę galią pirmiausia lèmé ginkluotujuc pajėgų sudètis ir ginkluotès kiekis. Karinis potencialas nėra lygus kariniam pajègumui (galiai), nes pirmasis yra teorinis vertinimas, rodantis, kokias ginkluotąsias pajëgas šalis ateityje galètų sutelkti, o karinè galia jau turimos pajègos. Pliki statistiniai skaičiai mažai ką pasako apie kitus svarbius veiksnius, tokius kaip karinè vadovybè, manevringumas, veiksmų staigumas, kariuomenès dvasinè būklè. Todèl ir galingiausia kariuomenè ne visada neišvengiamai laimès mūš ${ }^{196}$. Be to, pati savaime valstybių galia nieko nereiškia, jei nèra apmąstyta ir suformuluota strategija, suvoktas valstybès galios potencialas, apsvarstyti jos tikslai ir igyvendinimo būdai ${ }^{197}$. Ne vien divizijų ar armijų skaičiumi buvo matuojama valstybės karinè galia, bet ir ūkio ištekliais, kurie gali būti panaudoti karo reikmėms ${ }^{198}$.

Siekiant îvertinti Lietuvos ir Lenkijos karinès galios $(G k)$ komparatyvini santykị, išskyrème 8 esmines $G k$ sudedamąsias dimensijas. Šị santykị galima išreikšti apskaičiuojant atskirų valstybių karinei galiai ịtakos turinčių

\footnotetext{
1931928 m. Lenkija kariuomenei skyrè 31,08 \% biudžeto (1 gyv. - 29 Lt), 1929 m. - 38,2 \% (40 Lt), 1930 m. -36,9 \% (42 Lt), 1931 m. - 36,9\% (41,2 Lt), 1932 m. - 41,9 \% (37,7 Lt). Lietuva tuo metu skyrè: 1928 m. - 17,22 \% biudžeto (20,69 Lt), 1929 m. - 18,24 \% (21,21 Lt), 1930 m. - 17,45 \% (23,94 Lt), 1931 m. - 16,52 \% (23,34 Lt), 1932 m. - 16,83 \% (19,46 Lt): Bukevičius R. Karo biudžetas - taikos ir nepriklausomybès laidas// Mūsų žinynas. 1934, T. XXVI, Nr. 111, p. 495-496.

1941933 m. sausi 1 JAV doleris kainavo 9,98 Lt, rugsèji - 5,5 Lt, lapkriti - 6,08 Lt: Statistikos biuletenis. Kaunas, 1933, Nr. 12, p. 17. 1938 m. 1 JAV doleris kainavo 5,92 Lt: Statistikos biuletenis. Kaunas, 1938, Nr. 12, p. 21.

${ }^{195}$ Vaičenonis J. Lietuvos kariuomenės modernizacija (1926-1939) // Darbai ir dienos. T. 21. Red. L. Gudaitis. Kaunas, 2000, p. 158.

${ }^{196}$ Davies N. Kariaujanti Europa: 1939-1945 sunki pergale. Vilnius, 2009, p. 40-42.

${ }^{197}$ Statkus N., Motieka E., Laurinavičius Č. Geopolitiniai kodai: tyrimo metodologija. Vilnius, 2003, p. 9.

${ }^{198}$ Gustainis V. Karo baimè kovoje su karo pavojais// Kardas. 1937, Nr. 7, p. 157.
} 
dimensijų skirtumą ir išvedant bendrą skirtumo vidurkị ${ }^{199}$ pagal formulę: $G k=\frac{1}{m} \sum_{n=1}^{m} \frac{b_{n}}{a_{n}}$. Jeigu $1939 \mathrm{~m}$. Lietuvos $G k$ prilyginsime vienetui (1), tai, palyginus su Lenkijos $G k$, atitinkamai ${ }^{200} 1$ x 11,8 karto Lenkijos $G k$ didesne, o palyginus ( $S g k)$ atsižvelgiant ị gyventojų skaičių (c), santykis 1 x $0,86^{201}$ jau bus Lietuvos naudai.

Visa tai ịrodo, kad pagal santykines, atsižvelgiant ị gyventojų skaičių, investicijas i kariuomenę bei $S g k$, Lietuvos rodikliai aptariamuoju laikotarpiu, nors ir nedaug, buvo aukštesni. Tačiau Lietuva, būdama daug mažesnè valstybè, karių skaičiumi ir ginkluotès ištekliais negalejo varžytis su Lenkija ar juo labiau pranokti ją. Manytume, kad dvišalio karinio konflikto su Lenkija atveju Lietuva negalèjo tikètis didelès sèkmès, bet tvarkingas pajègu atsitraukimas, stabdant priešą ir išsilaikant keletą savaičių savo teritorijoje, buvo visiškai realus.

\section{IŠVADOS}

1. Lietuvos kariuomenès mobilizacijos planuose buvo numatyta, jog ginkluotuju pajègų, kurias turèjo sudaryti apie 150 000-160 000 karių, mobilizacija vyks decentralizuotai, kad priešo aviacija negalètų sunaikinti visu dalinių vienu smūgiu, o pati mobilizacija būtų greitai baigta. Tai leido tikètis, kad Lietuvos kariuomenè operatyviai užims gynybos pozicijas ir pradès karo veiksmus priešui dar neịsiskverbus ị krašto gilumą.

2. Iš anksto parengti kariuomenès mobilizacijos ir karo finansavimo bei aprūpinimo planai būtų garantavę sẻkmingą kariuomenès materialinị aprūpinimą pirmosiomis pajègų mobilizacijos ir karo dienomis. $\mathrm{O}$ iš turimų vidaus ištekliu Lietuva savo pajègas maistu ir pašaru galejo aprūpinti ir ilgesnị laiką. Tačiau netenka abejoti, kad karo veiksmams užsitęsus jos vadovybè užsienyje būtų buvusi priversta ieškoti ne tik diplomatinès ir karinès, bet ir materialinès pagalbos, ypač ginkluotès ir amunicijos.

${ }^{199}$ Karinès galios dimensijos (tankai, karo lèktuvai, artilerijos pabūklai, kulkosvaidžiai, šautuvai, kariuomenė karo metu, kariuomenė taikos metu, KAM išlaidos mln. Lt) skaitiklyje $b$ rašomi Lenkijos, o vardiklyje $a$ Lietuvos duomenys, trupmenų suma dalijama iš $m$, kuris reiškia $G k$ lemiančių sudedamụjų dimensijų skaičių.

${ }^{200} G k=\left(\frac{887}{44}+\frac{712}{115}+\frac{7334}{549}+\frac{42915}{4501}+\frac{1229400}{131338}+\frac{1350000}{125433}+\frac{350000}{24000}+\frac{894}{85,193}\right): 8=11,8$

Iš eilès: tankai; karo lèktuvai; artilerijos pabūklai; kulkosvaidžiai; šautuvai; kariuomenè karo metu; kariuomenè taikos metu; KAM išlaidos.

${ }^{201}$ Pagal formulę: $S g k=G k:\left(\frac{c}{c_{1}}\right) S g k=11,8:\left(\frac{35,339}{2,575}\right)=0,86$ 
3. XX a. ketvirtojo dešimtmečio antroje pusejje Lietuvos kariuomenè pagrindiniu eventualiu priešu laikė Vokietiją, o Lenkija tik viešajame diskurse buvo įvardijama kaip aktuali grèsmè, tačiau realiai laikyta ne tokiu svarbiu priešu, galinčiu pulti tik kilus karui su SSRS arba Vokietija. Užtikrinant Lietuvos karini saugumą svarbus vaidmuo teko SSRS, nes jos pozicija galejjo lemti Lenkijos kariuomenès laikyseną Lietuvos atžvilgiu ir net užkirsti kelią lenkų ir lietuvių ginkluotam konfliktui. Tačiau kartu Lietuvos diplomatai turejjo palaikyti gerus santykius bent su viena iš didžiụjų kaimynių (Lenkija arba Vokietija), nes karas dviem frontais laikytas katastrofa.

4. Lietuvos kariuomenè rengèsi išimtinai gynybiniam karui. Kariuomenès štabe buvo manoma, kad Lietuva ị karą ateityje gali būti ịtraukta tik prieš savo valią, regione kilus plataus masto Lenkijos, Vokietijos ir SSRS kariniam konfliktui. Karo su Vokietija atveju lietuviai galejo tikètis Latvijos kariuomenès paramos, tačiau ir Lenkijai įsiveržus į Lietuvą koalicijos klausimas būtų buvęs komplikuotas, nes Latvija buvo artima Lenkijos partneré, o Lietuvos sajungininkę SSRS laikė pagrindine grèsme.

5. Vertinant Lietuvos ir Lenkijos santykius akivaizdu, kad Lenkija, turinti 7 kartus didesnę teritoriją ir 13,7 karto daugiau gyventojų, kariniu požiūriu buvo daug stipresnè valstybė. Lenkijos kariuomenè taikos metu buvo 15 kartų didesnè, artilerijos pabūklų turèjo 13,4, karo lèktuvų - 6,2, tankų ir tankečiu - 20 kartų daugiau. Jos karinè galia $(G k)$ 11,8 karto pranoko Lietuvos karinę galią. Tačiau atsižvelgiant ị valstybių gyventojų skaičių, Lietuva atsiliko tik tankų ir artilerijos pabūklų, bet lenkè lèktuvų, šautuvų ir kulkosvaidžių skaičiumi, o jos santykinė karinè galia $(S g k)$, nors ir nedaug, bet buvo didesne. Tai byloja, kad Lietuva savo kariniam saugumui skyré ne mažesnị dėmesį nei Lenkija. Visa tai leido tikètis, kad kilus karui Lietuvos kariuomené galès atlaikyti pirmuosius priešo smūgius, o lenkų pajègu persvarai pasiekus kritini tašką - organizuotai atsitraukti ir internuotis Latvijoje. Žinoma, padètis visiškai būtų pasikeitusi, jei ị karą su Lietuva būtų ìsitraukusi ir Vokietija. Tada Lietuvos kariuomenès pralaimejjimas būtų buvęs neišvengiamas ir greitas. 
1 priedas $1935-1938 \mathrm{~m}$. Lietuvos kariuomenès mobilizacijos schema ${ }^{202}$

\section{KARIUOMENĖS BŪSTINE்}

Kaunas

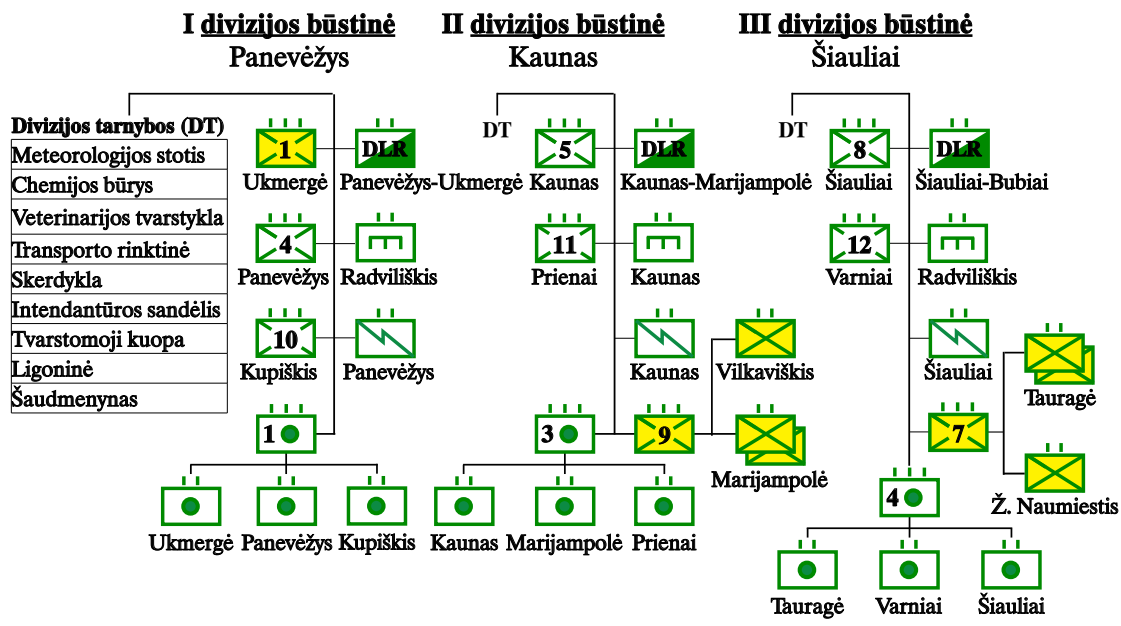

IV divizijos būstinè Kèdainiai
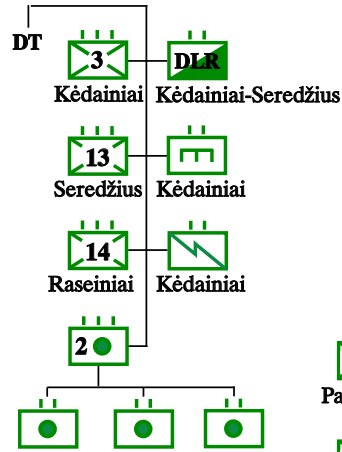

Kèdainiai Seredžius Raseiniai
I pėstininku brigados būstinè Klaipèda

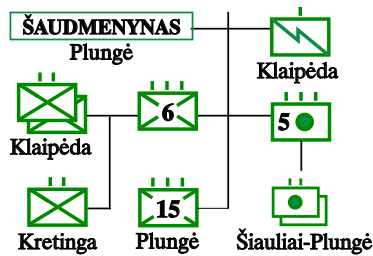

Atsargos kariuomené

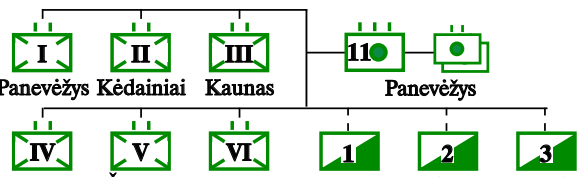

Kaunas Šiauliai Plunge Kaunas Alytus Kupiškis
II pèstininku brigados būstinè Kaunas

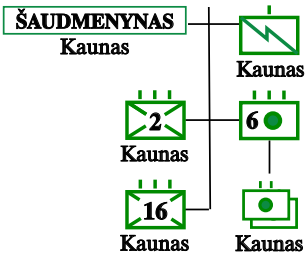

${ }^{202}$ Mob. tv. Nr. 11 ir Nr. 12: papildomų ir kuriamų kariuomenès dalių ir įstaigų sąrašo papildymai bei pakeitimai, paskelbti nuo 1935 m. rugpjūčio 16 d. iki 1939 m. kovo 13 d. LCVA. f. 929 , a. 3, b. 848, 1. 1-233. 
$\underline{\text { Karo technikos daliniai }}$

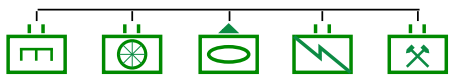

Kaunas Kaunas Radviliškis Kaunas Radviliškis

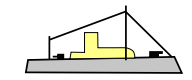

Mokomasis karo laivas "Prezidentas Smetona“

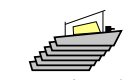

VRM kateriai „Partizanas“, „Aitvaras“, „Žaibas“, „Šaulys“, „Savanoris“, „Lietuvaite“"
Pasienio apsaugos batalionai (PAB)

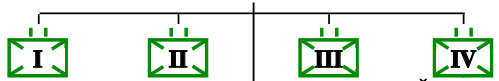

Kretingos aps. Tauragès aps. Tauragès aps. Šakių aps.

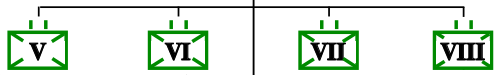

Vilkaviškio aps. Marijampolès aps. Seinų aps. Alytaus aps.
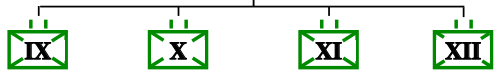

Trakų aps. Ukmergès aps. Utenos aps. Zarasų aps.

\section{$\underline{\text { Karo aviacijos štabas }}$} Kaunas

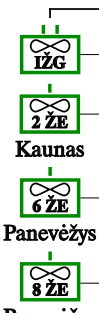

Panevėžys

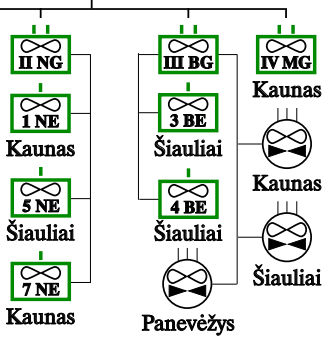

\section{Priešlèktuvinès apsaugos štabas}

Kaunas

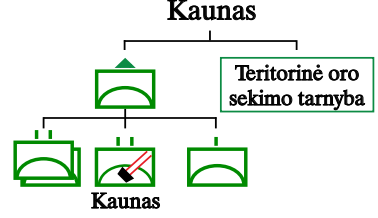

V. Jokubauskas, 2010

\section{$\underline{\text { Kavalerija }}$}

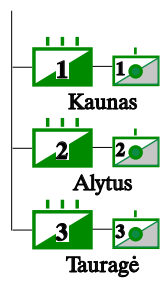

$\begin{aligned} & \text { Pėstininkų } \\ & \text { (priedangos) pulkas }\end{aligned}$
$\begin{aligned} & \text { Péstininkų } \\ & \text { batalionas }\end{aligned}$


2 priedas 1939 m. Lietuvos kariuomenès mobilizacijos schema ${ }^{203}$

\section{KARIUOMENĖS BŪSTINE்}

\section{Kaunas}
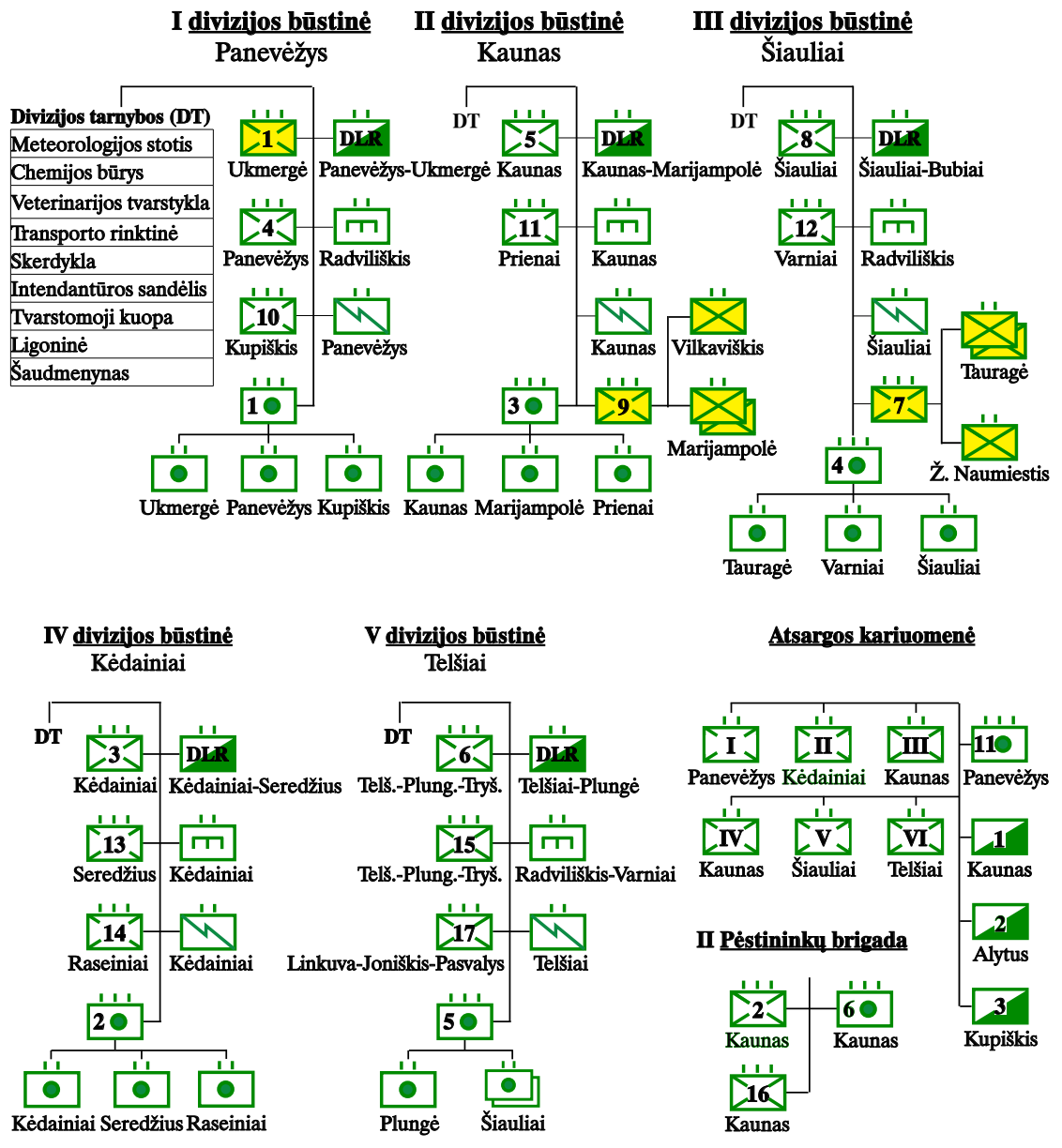

${ }^{203}$ Mob. tv. Nr. 11 ir Nr. 12: papildomų ir kuriamų kariuomenės dalių ir įstaigų sąrašo papildymai bei pakeitimai, paskelbti nuo 1935 m. rugpjūčio 16 d. iki 1939 m. kovo 13 d. LCVA. f. 929 , a.. 3, b. 848, 1. 1-233; Kariuomenès štabo III skyrius, 1939 m. balandžio 15 d. LCVA, f. 929, ap. 5 , b. $460,1.209$. 
$\underline{\text { Karo technikos daliniai }}$

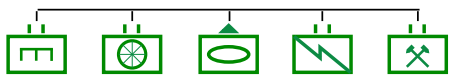

Kaunas Kaunas Radviliškis Kaunas Radviliškis

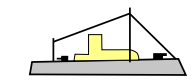

Mokomasis karo laivas „Prezidentas Smetona“

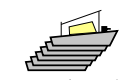

VRM kateriai „Partizanas“, „Aitvaras“, „Žaibas“, „Šaulys“, „Savanoris“, „Lietuvaitė“
Pasienio apsaugos batalionai (PAB)

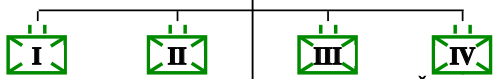

Kretingos aps. Tauragès aps. Tauragès aps. Šakių aps.

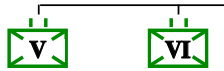

Vilkaviškio aps. Marijampolès aps.
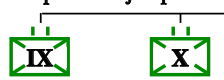

$\left[\begin{array}{l}1 \\ x^{\prime}\end{array}\right.$

Trakų aps. Ukmergės aps. Utenos aps. Zarasų aps.

\section{$\underline{\text { Karo aviacijos štabas }}$}

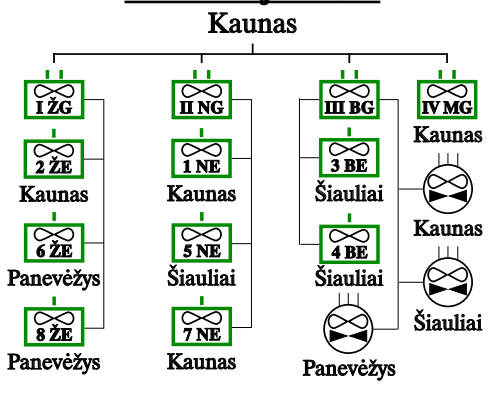

\section{Priešlèktuvinès apsaugos štabas}

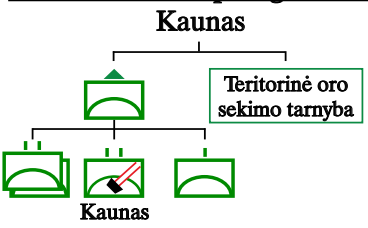

\section{$\underline{\text { Kavalerija }}$}

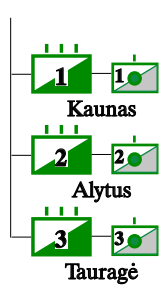

V. Jokubauskas, 2010 
LIETUVOS RESPUBLIKOS KARIUOMENE் 1918-1940 M.

3 priedas Lietuvos kariuomenès atsargos karių skaičius 1926-1940 m.

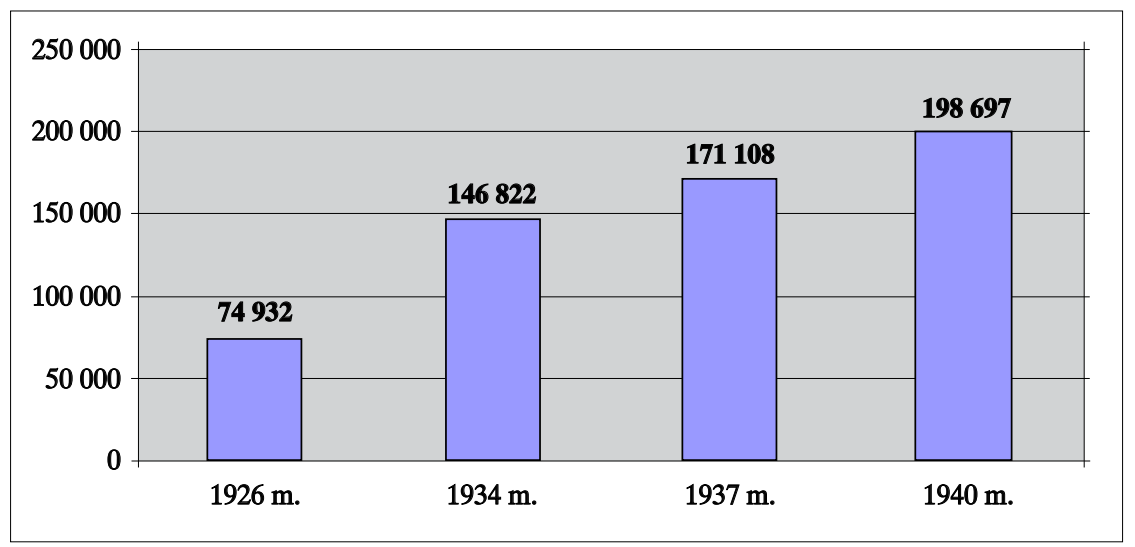


Lietuvos kariuomenès kariniai planai ir

resursai eventualaus karo su Lenkija atveju 1938-1939 m.

4 priedas Lietuvos kariuomenès operacijų planas Nr. 3 „L“ 1937-1939 m.

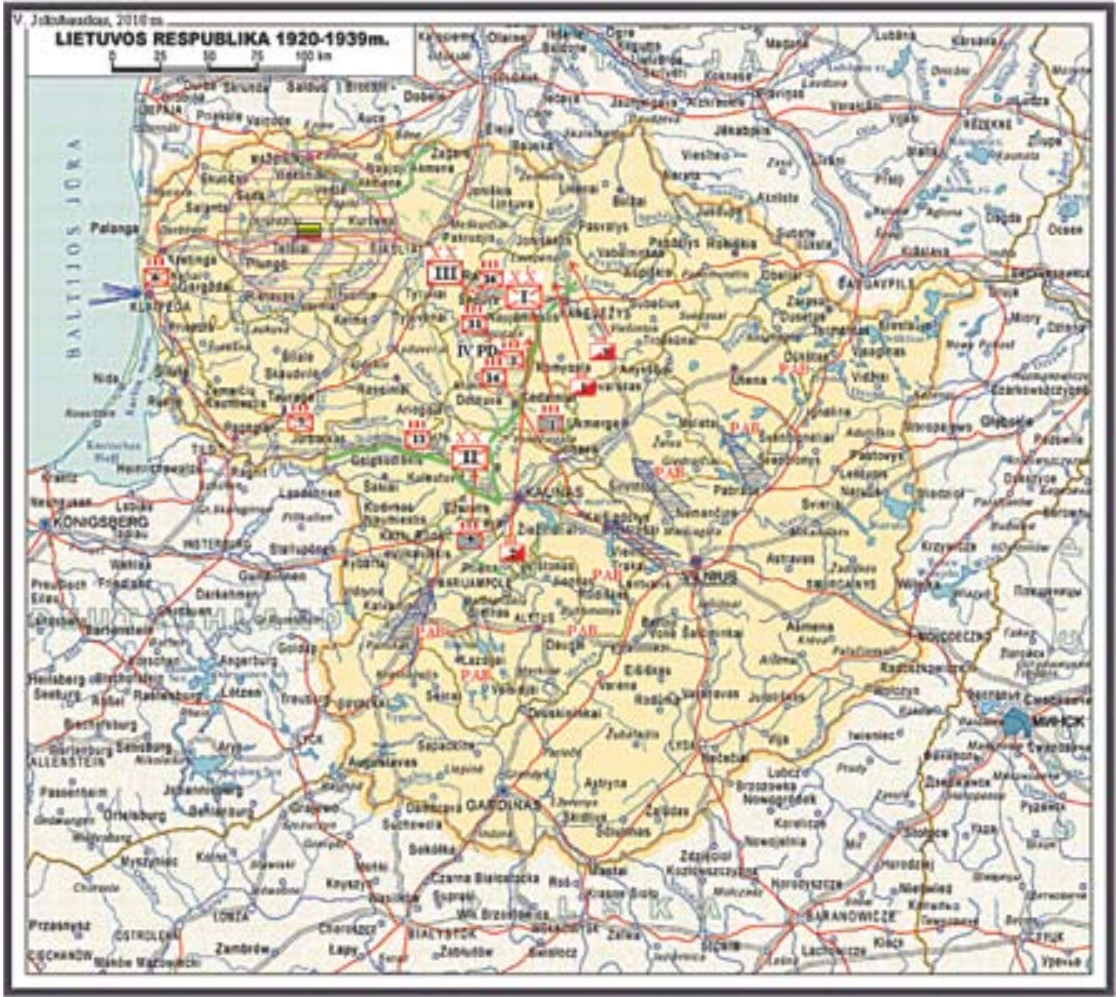

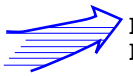

Pagrindinès galimo

Lenkijos puolimo kryptys

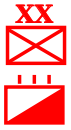

Pèstininkų divizija

Kavalerijos pulkas

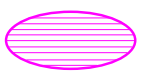

LR Vyriausybès ir

centrinių valdžios įstaigu evakuacijos rajonas

LR Prezidento evakuacijos vieta

Pèstininku

(priedangos) pulkas
Lietuvos kariuomenès gynybos linijos PAB $\begin{aligned} & \text { Pasienio apsaugos } \\ & \text { batalionas }\end{aligned}$ 
5 priedas Lietuvos kariuomenès operacijų planas Nr. 2 „V+L“ 1937-1939 m.

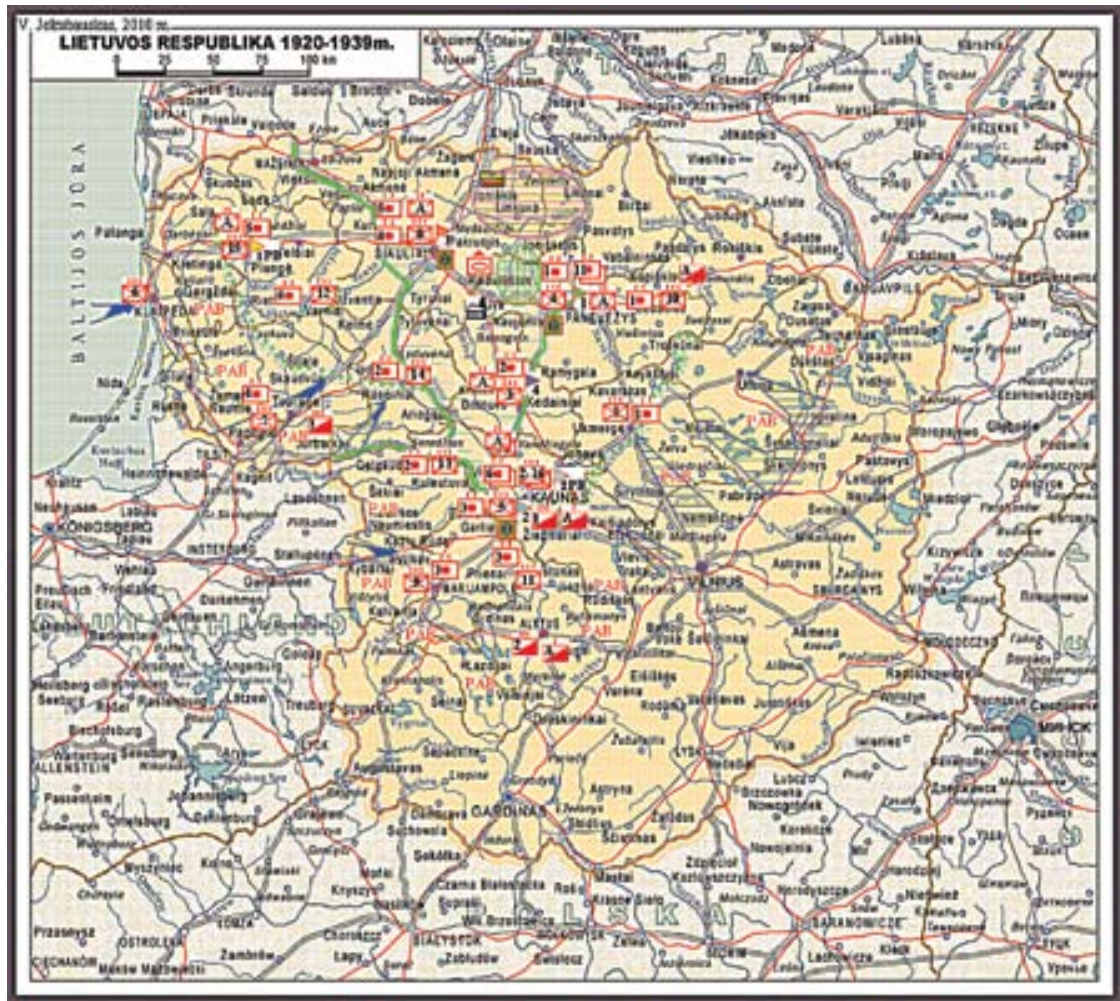

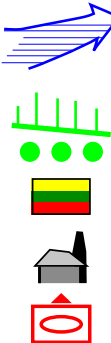

Pagrindinès galimo
Lenkijos puolimo
kryptys

Lietuvos kariuomenès gynybos linijos

LR Prezidento evakuacijos vieta

Linkaičių ginklų dirbtuvès

Šarvuočių rinktinė

PAB Pasienio apsaugos batalionas

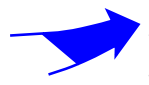

Pagrindinès galimo Vokietijos puolimo kryptys

$P_{1} P_{1 P B}$

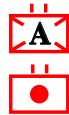

Divizijų ir brigadų štabai

Péstininkų atsargos batalionas

Artilerijos grupè

$\sum^{11}$

Pèstininkų pulkas
LR Vyriausybès ir centrinių valdžios įstaigų evakuacijos rajonas Lietuvos kariuomenès pagrindinių pajègu sutelkimo rajonas

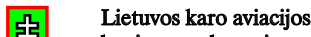
bazès, aerodromai

Kavalerijos pulkas

Kavalerijos atsargos eskadronas 


\title{
DES PLANS MILITAIRES ET DES \\ RESSOURCES DE L'ARMÉE \\ LITUANIENNE DANS LE CAS \\ DE LA GUERRE ÉVENTUELLE CONTRE \\ LA POLOGNE DANS LES ANNÉES 1938-1939
}

\author{
Vytautas Jokubauskas, \\ Université de Klaipéda
}

Tout le période entre la guerre, des relations de la Lituanie et de la Pologne étaient tendues et hostiles à cause de l'occupation de la région de Vilnius par la Pologne. Il est donc compréhensible que dans la doctrine militaire de Lituanie la Pologne était nominée longtemps comme l'ennemie principale. La situation a changé dans les années 1934 quand les troupes des ennemies éventuelles étaient supplées par l'Allemagne, et à force elle a devenu la menace principale. Toutefois, la Pologne était une menace toujours très importante au discours public. En 1935, des réformes essentielles de la formation militaire, de la planification et de la structure étaient commencées à faire dans l'armée lituanienne, et en 1937 les trois nouveaux plans opérationnels étaient confirmés : $\mathrm{N}^{\circ} 1$ « $\mathrm{A} »$ (Allemagne), $\mathrm{N}^{\circ} 2$ 《 $\mathrm{A}+\mathrm{P} »$ (Allemagne + Pologne) et $\mathrm{N}^{\circ} 3 \ll \mathrm{P} »$ (Pologne). Dans le premier plan, des actions de la défense étaient prévues en cas de l'attaque par l'Allemagne, dans le deuxième - en cas de l'attaque commune de l'Allemagne et de la Pologne, cependant ce plan était destiné essentiellement dans le cas si dans la région une guerre à grande échelle procéderait. Le troisième plan était destiné afin de repousser la menace polonaise. Dans la quatrième décennie du $\mathrm{XX}$ siècle, la Lituanie préméditait essentiellement pour la guerre défensive. Au cas de la guerre, des plans opérationnels, de plus des plans du financement des actions militaires et de la réquisition du capital étaient élaborés. Les relations de l'armée et des civils lors de la guerre devaient être contrôlées par les règlements acceptés en particulier. Au cas de la guerre en 1938, la Lituanie planifiait de mobiliser les 4 divisions des infanteries et les 2 brigades (16 infanteries et 6 unités d'artillerie), les 12 bataillons de la sécurité frontalière, les 3 unités de cavalerie, les 3 escadrons de cavalerie de réserve, les 6 bataillons des infanteries, l'unité d'artillerie de réserve et les unités comprenant des chars de combat, des 
télécommunications et des ingénieurs. Dès le début des années 1939, il y devait être les 5 divisions des infanteries, 1 brigade (les 17 unités des infanteries) et les unités déjà mentionnées. Lors de la guerre, la Lituanie devait avoir les 150000 soldats environ, de plus les unités des tireurs et la police y existaient.

En comparant le pouvoir militaire de Lituanie et de l'ennemie éventuelle polonaise, il est compréhensible qu'à cause du différent taille des pays, le pouvoir de la Pologne était nettement plus grand $(1 \times 11,8)$, toutefois en comparant les mêmes données prenant en considération le nombre des habitants, le taux changeait en faveur de Lituanie $(1$ x 0,86$)$. Néanmoins, il n'est pas possible d'affirmer que la Lituanie était capable de commander avec succès la guerre contre la Pologne d'une manière indépendante et de la gagner. C'est juste montre que les forces lituaniennes ne convenaient pas relativement aux forces de l'ennemie éventuelle, et que l'armée lituanienne ainsi que la sécurité militaire avaient obtenu beaucoup de l'attention. 


\title{
MILITARY PLANS AND RESOURCES OF THE LITHUANIAN ARMED FORCES IN CASE OF EVENTUAL WAR WITH POLAND IN 1938-1939
}

\author{
Vytautas Jokubauskas \\ Klaipéda University
}

Throughout the interwar period relations between Lithuania and Poland, as the latter occupied Vilnius region, were tense and even hostile, so it is natural that Lithuania's military doctrine for a long time listed Poland as a main enemy. The situation changed around 1934, when Germany was added to the list of eventual enemies, and eventually it became a major threat, but in the public discourse Poland remained the major threat thereinafter. In 1935 the Lithuanian Armed Forces started the essential structural, planning and military education and training reforms, and in 1937 the plans were approved for three new operations: No. 1 "V" (Germany), no. 2 "V + L '(Germany + Poland) and Art. 3 "L" (Poland). The first plan has provided the actions in case of defense against the German attack, the second - against Germany and Poland, but this plan was mainly designed to be the case if the region would meet a large-scale war. The third plan was intended to counter the threats from Poland. In the thirties of the $20^{\text {th }}$ century Lithuania basically was preparing for defensive war. For the case of war there were prepared not only plans of operations but also financing plans and asset requisition plans, and the relations between the military and civilian parties was to be regulated by specially adopted laws. In case of war in 1938 Lithuania planned to mobilize 4 infantry divisions and 2 brigades (16 infantry and 6 artillery regiments), 12 border guard battalions, 3 cavalry regiments, 3 cavalry squadrons in reserve, 6 infantry battalions, 1 artillery regiment in reserve, tanks, communications and engineering units. Since 1939 the start was to be 5 infantry divisions, 1 brigade (17 infantry regiments) and already mentioned units. During the war Lithuanian troops was to be about 150,000 men, in addition to the divisions of the Union of Riflemen and the police.

Comparing the military power of Lithuania and Poland as an eventual enemy it is clear that because of the different size of countries the Polish power was significantly higher ( 1 x 11.8), but comparing the same data ac- 
cording to the population ratio, then the power changed in favour of Lithuania $(1 \times 0.86)$. However, this does not mean that Lithuania was able to lead independently and successfully the war with Poland and win it, but it testifies that the Lithuanian forces could relatively outface the possible hostile forces, that the significant attention was given both to the Lithuanian army and military security. 